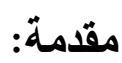

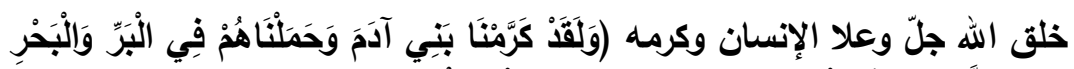

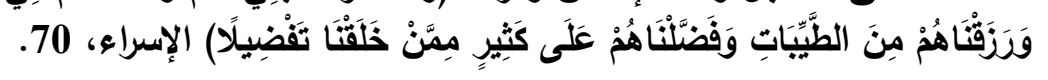

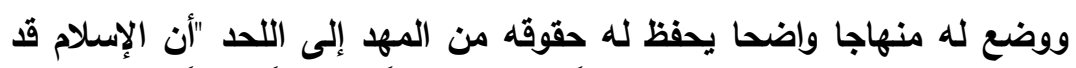

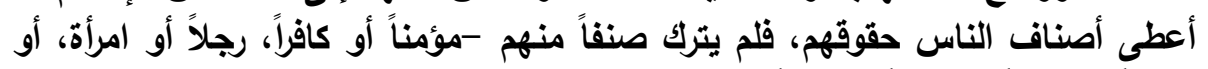

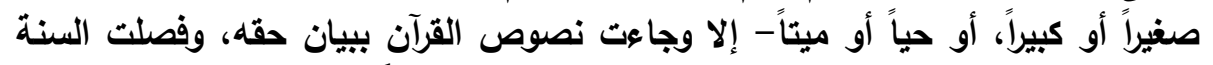

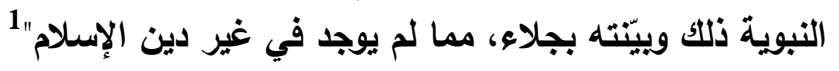

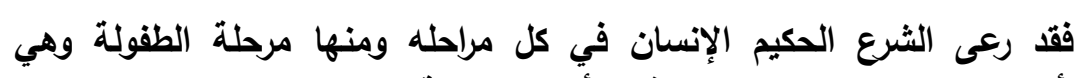

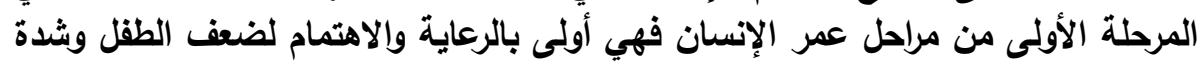

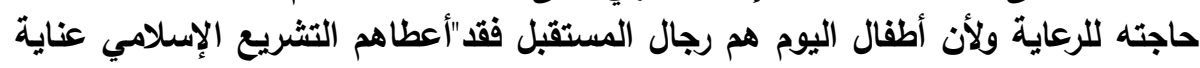

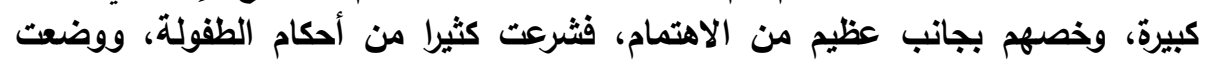

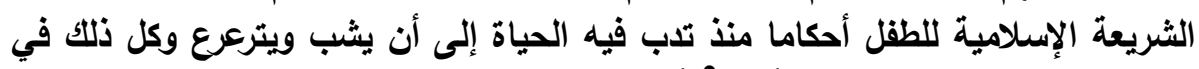

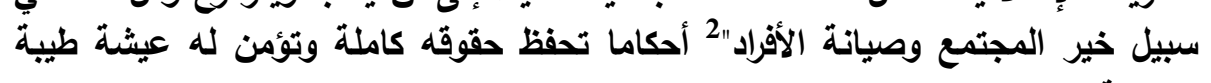

$$
\text { ومباركة. }
$$

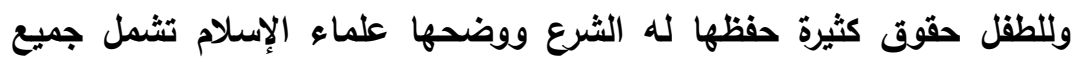

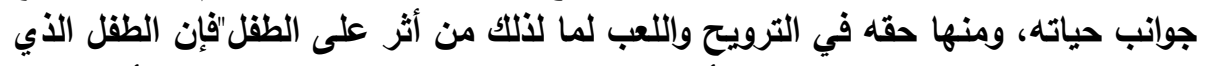

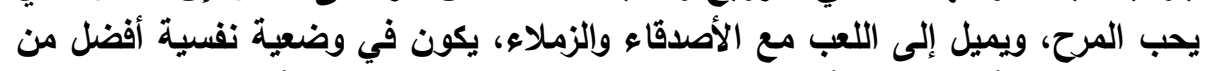

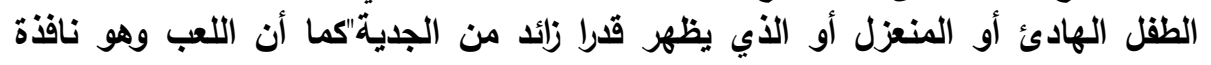
الطقل على العالم ومن خلاله تبنى وتطهز شخصيته.

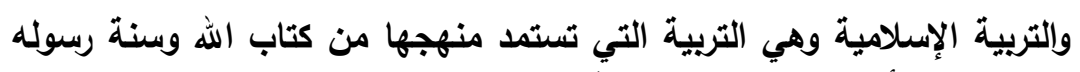

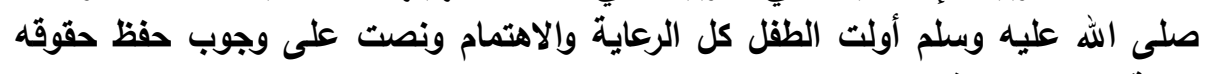
كاملة ومنها حقه في اللعب.

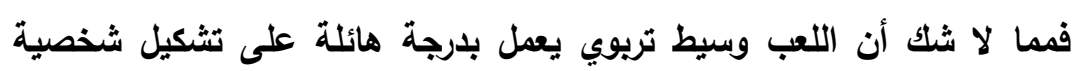

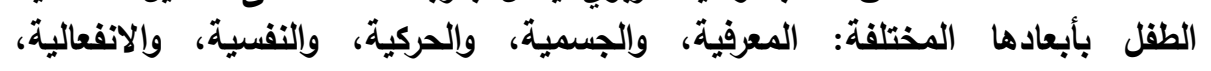
والاجتماعية. ولا يرجع مصدر هذه الأهمية إلى أن الطقل يقضي معظم وقته في اللعب 'يحيى محد زمزمي: المنهج الأخلاقي وحقوق الإنسان في القرآن الكريم، الرياض. مؤتمر الدفاع

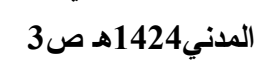

2حسنين بوادي: حقوق الطفل بين الثريعة الإسلامية والقانون الدولي. الإسكندرية. دار الفكر الجامعي. 1426، صن49 بون 
الأي يستثير اهتمامه فحسب، وإنما إلى حقيقة أن اللعب يحدث تغييرات وتطويرات في

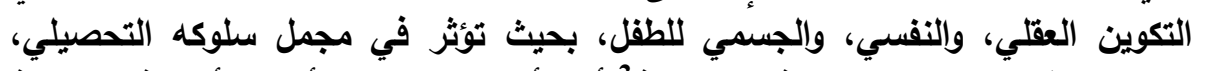

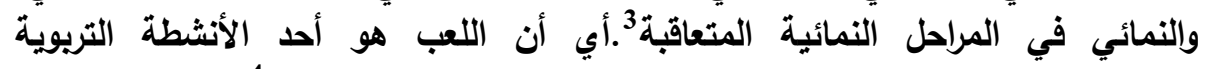

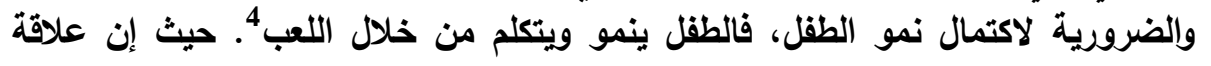

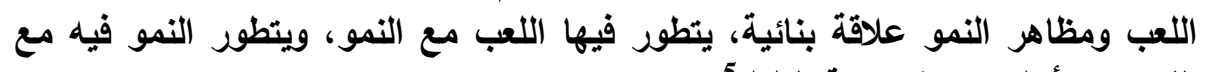
اللعب من أجل بناء شخصية الطفل 5.

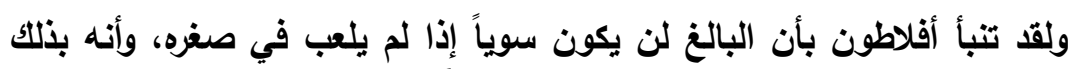

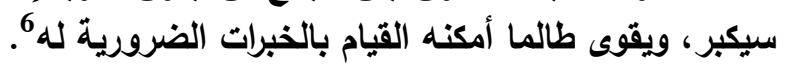

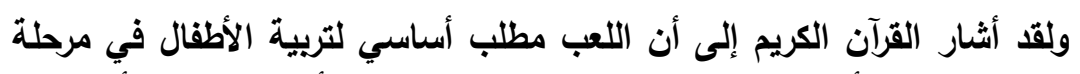

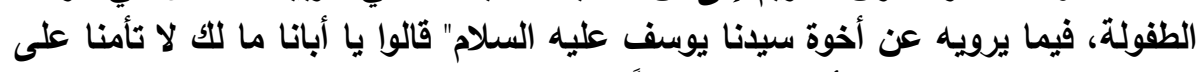

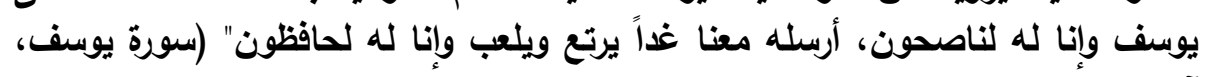
آيه112، 12، 12.

كما نلتمس ذلك في نصوص نبوية شريفة عرضت لقيمة اللعب، وأهميته

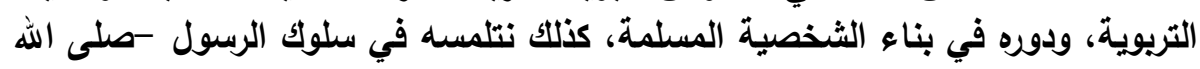

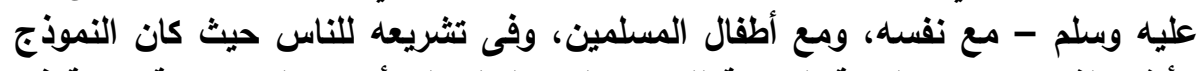

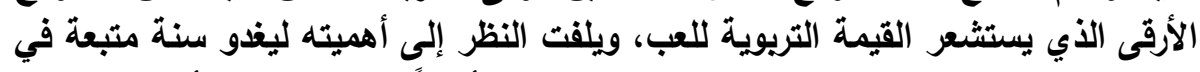

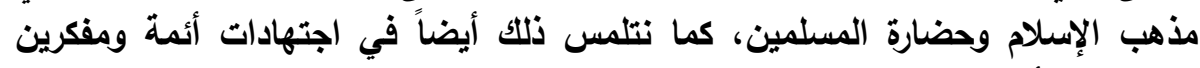

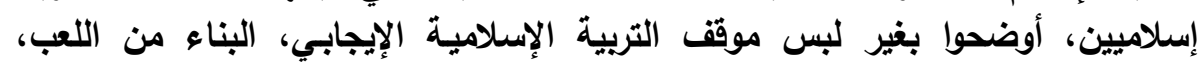
طبيعته، ووظائفه 7.

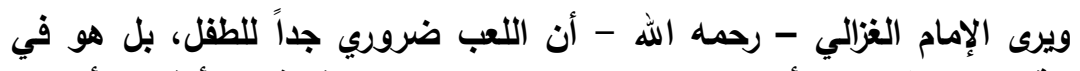

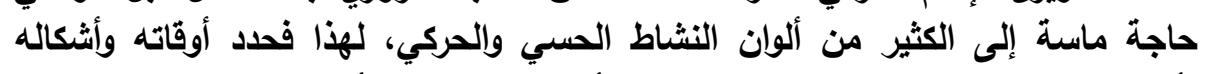

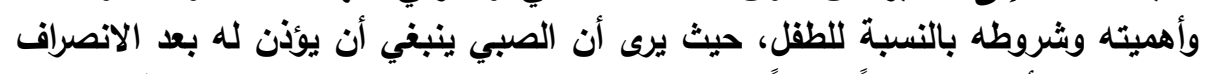

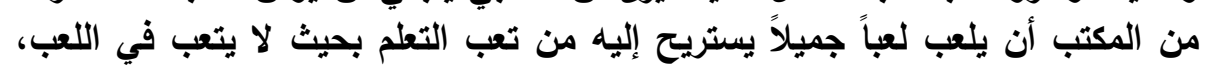

3 أحمد بلقيس، وتوفيق مرعى: الميسر في سيكولوجية اللعب. ط3، دار الفرقان. عمان، 1987م، ص149.

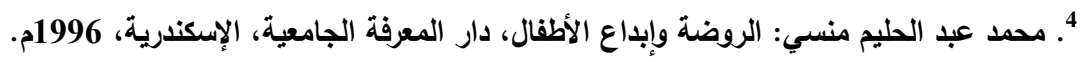

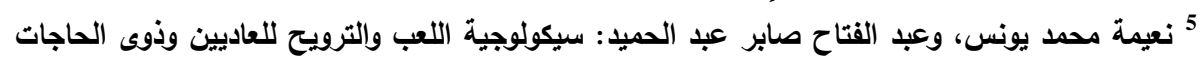

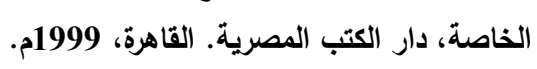

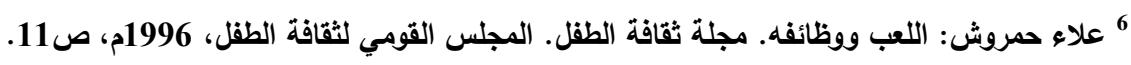
7 حسن إبراهيم عبد العال: " اللعب مدخل وظيفي للتربية الإسلامية". دراسات تريوية. المجلد السابع. الجزء

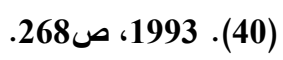


مجلة كلية التربية، جامعة الأزهر ، العدد: (164 الجزء الثالث) يوليو لسنة 2015م

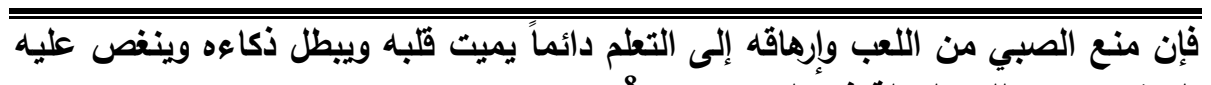

العيش حتى يطلب الحيلة في الخلاص من منه العنه

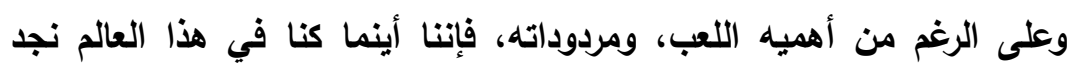

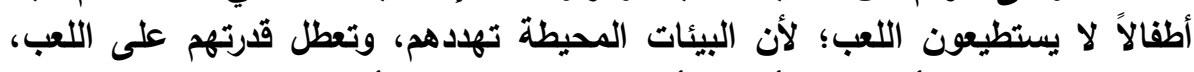

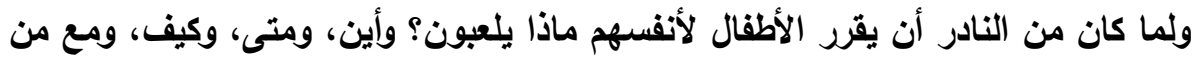

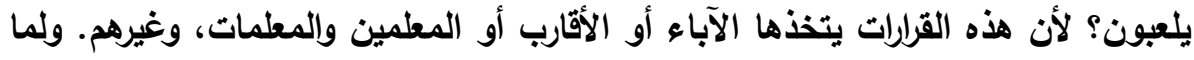

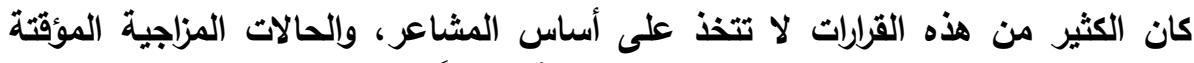

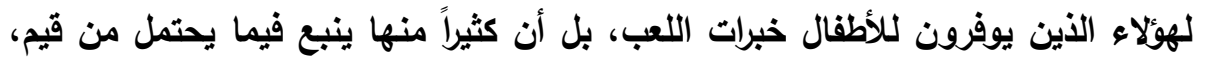

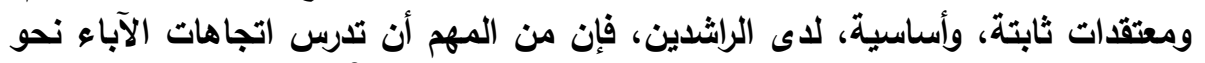

اللعب لما لهذه الاتجاهات من مساس بأسية، لأصحة النفسية للأطفال 9.

موضوع الدراسة:

رغم أهمية مرحلة الطفولة كمرحلة تأسيس وينيان إلا أن المتابع يلحظ قصورا في

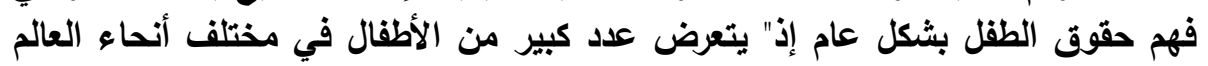

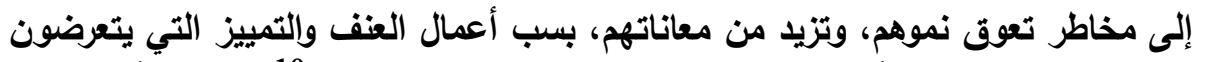

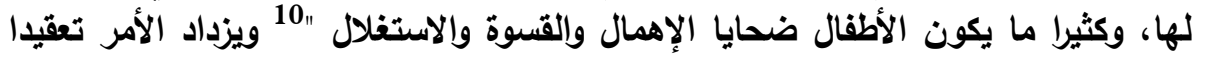

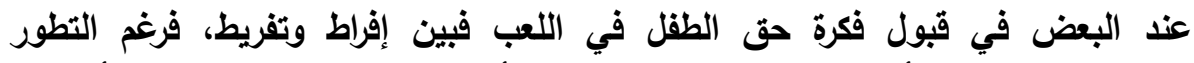

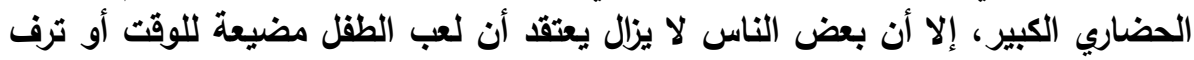

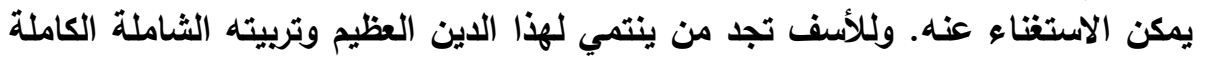
ومع ذلك لا يؤمن بهذا الحق للطقل. أسئلة الدراسة: تسعى الدراسة للإجابة عن السؤال الرئيسي التالي: ما حق الطقل في اللعب من منظور التربية الإسلامية؟ الإسية ويتفرع منه الأسئلة التالية: • ما مفهوم الطفولة وما أهم خصائصها؟ • ما مفهوم الحقوق وما هي حقوق الطقل في الإسلام؟ • ما خصائص ووظائف اللعب؟

8 أبو حامد الغزالي: إحياء علوم الدين، ج3. المكتبة التجارية الكبرى. القاهرة

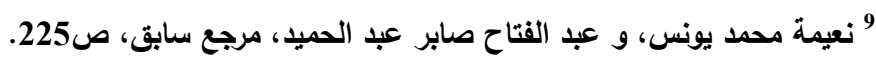

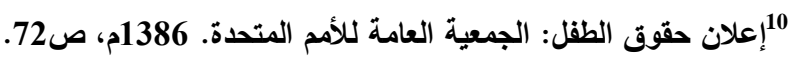




$$
\text { أهداف الدراسة: المعان }
$$

- - التعرف على مغنى وخصائص الطفولة.

- - التعرف على مغنى الحقوق، وعلى حقوق الطفل في الإسلام. - -

- - التعرف على أهمية اللعب في تكوين شخصية الطفل.

- - التعرف على حق الطفل في اللعب من منظور التربية الإسلامية.

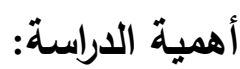

- تبرز أهمية هذه الدراسة من أهمية التربية الإسلامية كتربية شاملة ومتكاملة ترعى الإنسان في صغره وكبره، وتوجهه التوجيه السليم.

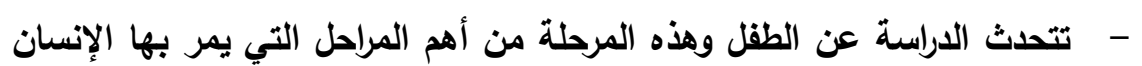

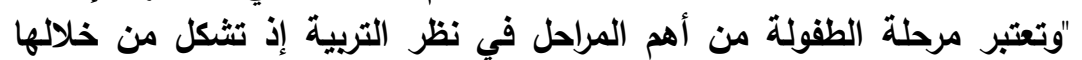

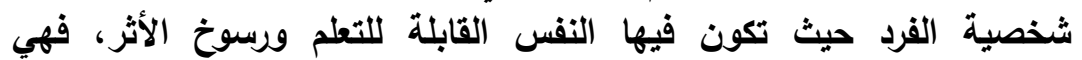

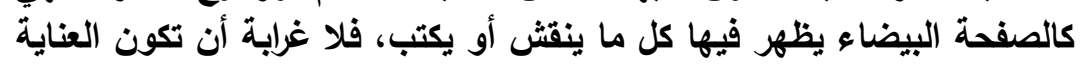

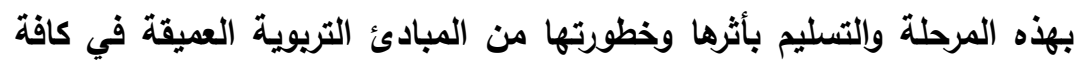
المجتمعات الإنسانية "11 بلترهات

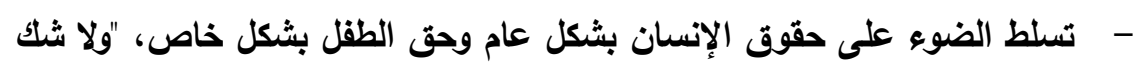

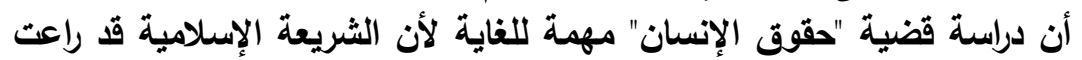

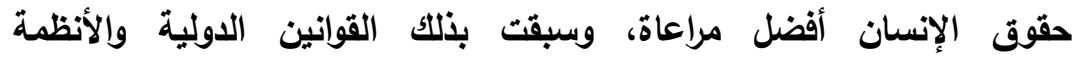
الوضعية" الوالمنان

- - تتحدث الاراسة عن حق الطفل في اللعب واللعب تعبير حر تلقائي في العملية

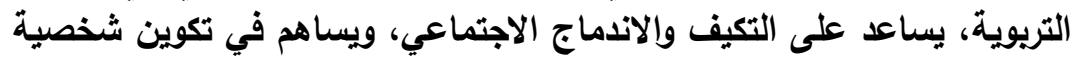

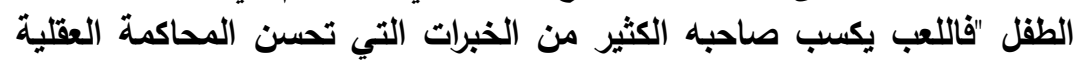

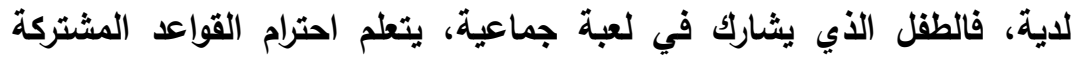

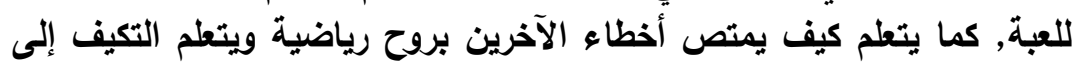

11"محمد صالح العلوي: خطاب النبي صلى الله عليه وسلم للطفل المسلم وتطبيقاته التريوية. رسالة

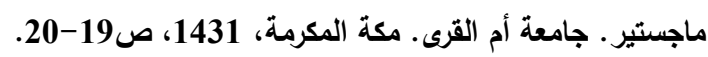

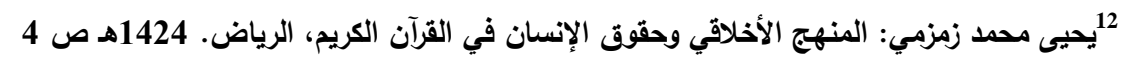


مجلة كلية التربية، جامعة الأزهر، العلد: (164 الجزء الثالث) يوليو لسنة 2015م

جانب محاولة التعبير عن السلوك الشخصي وفق منطق مقبول، ومن هنا ندرك

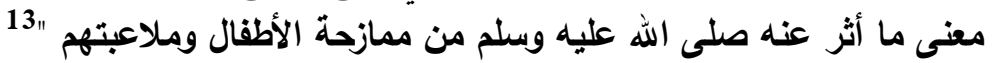

$$
\text { منهج الاراسة: }
$$

استخدم الباحث المنهج الوصفي والذي يعرف بأنه "دراسة الواقع أو الظاهر كما

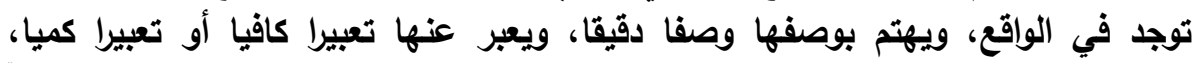

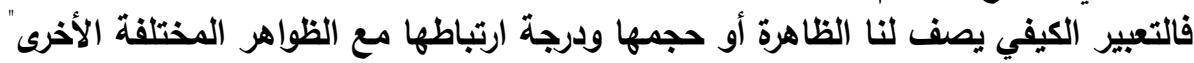

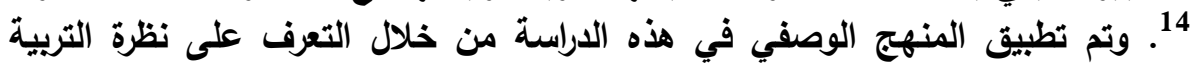

الإسلامية لحق الطقل في اللعب.

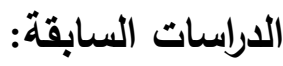

1. دراسة داونيز (2000)Downes)

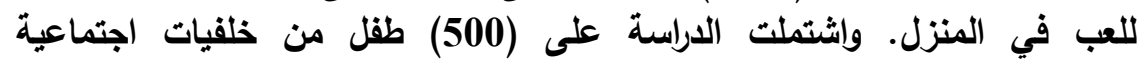
واقتصادية وثقافية مختلفة. وأظهرت نتائج الدراسة أن استخدام الطقل الكمبيوتر كأداة

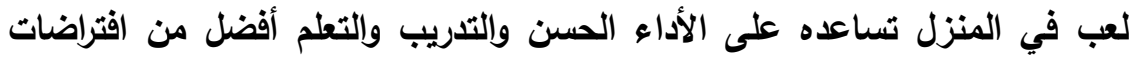
أساليب التدريس والتعلم داخل المدرسة.

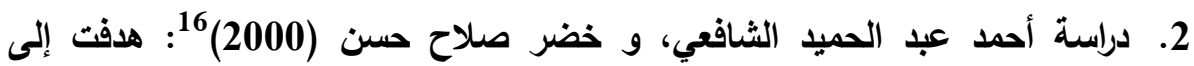
التعرف على منزلة و أهمية اللعب في الفكر التريوي الإسلامي وفى الفيد الفكر التربوي

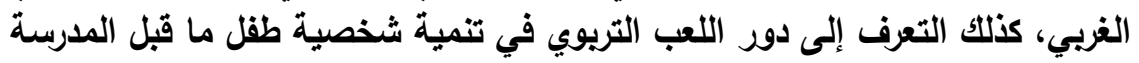

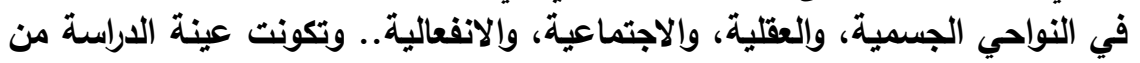

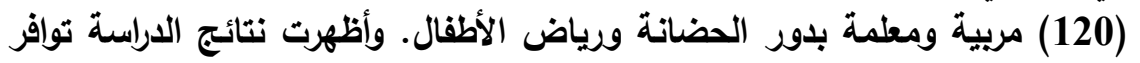

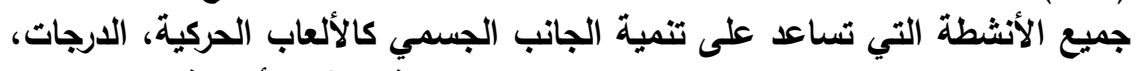

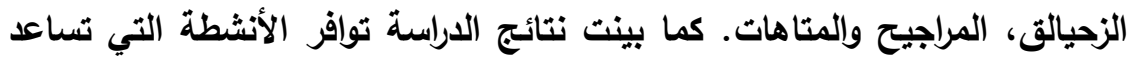

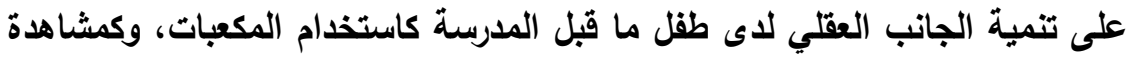

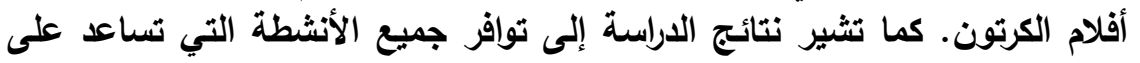

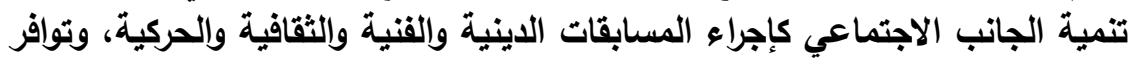

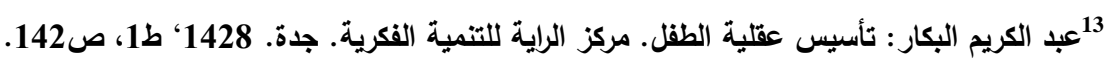

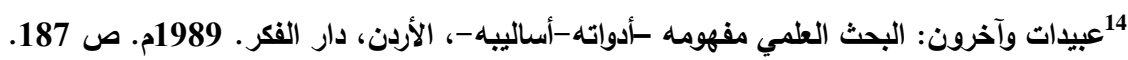
${ }^{15}$ Downes T. (2000): Blending Play, Practice and Performance. Learning with Computers at home. University of Western Sydney, Macarthur. AARE Australian Association for Research in Education 16 أحمد عبد الحميد الثافعي، و خضر صلاح حسن (2000): دور اللعب في تنمية بعض جوانب شخصية

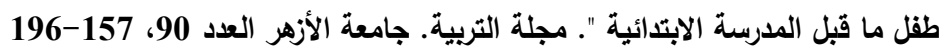


الأنشطة التي تساعد على تنمية الجانب الانفعالي كالقصص والحكايات واللعب باستخدام الصلصال واللعب بالحروف الهجائية والتمثيليات والأناثيد.

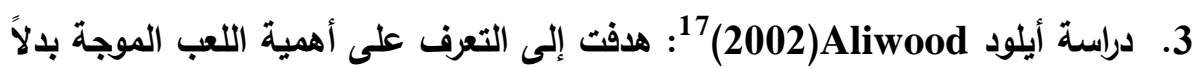

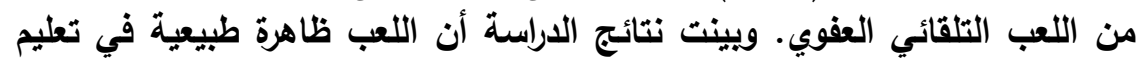

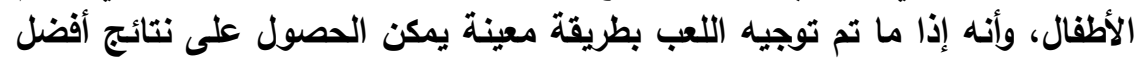

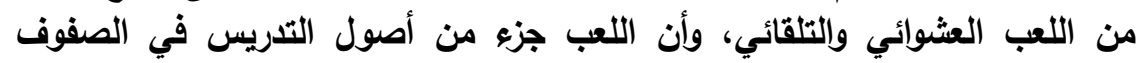

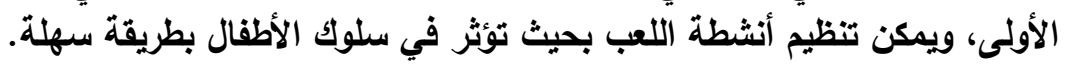

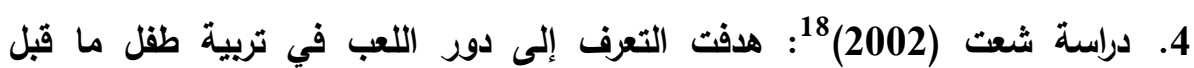

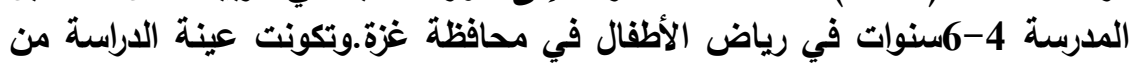

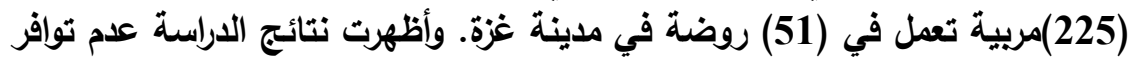

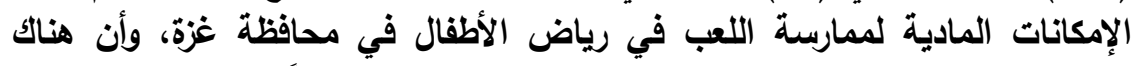

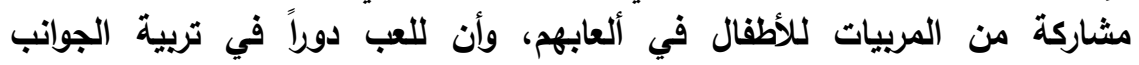
الجسمية، والعقلية، والانفعالية، والاجتماعي.

5. دراسة البلهان (2005) 19: هدفت إلى تحديد أثر استخدام أنثطة اللعب على التفكير

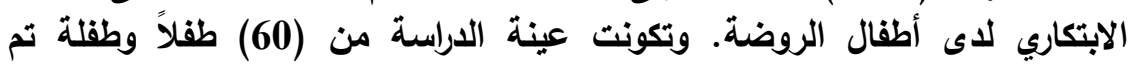

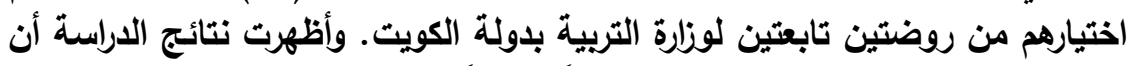
أنشطة اللعب التي يمارسها الأطفال لها أثراً واضحاً لعنى بلى نمو تفكيرهم الابتكاري. 6. دراسة غيلسون Gleason (2005) 20: هافت الدراسة إلى التعرف على اتجاهات

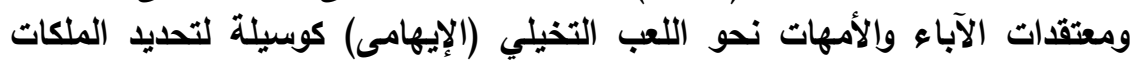

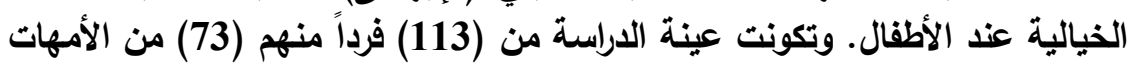
و (40) من الآباء. وبينت نتائج الدراسة أن أباء وأمهات الأطفال رأوال الألعاب من الأبهات

17 Aliwood J.(2002):Homogenizing Play: Governing Preschool Childhoods, Charles Sturt University, AARE - Australian Association for Research in Education

18 عزة عبد الحميد شعت: " دور اللعب في تريبة طقل ما قبل المدرسة 4-6 سنوات في رياض أطفال

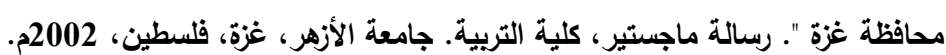

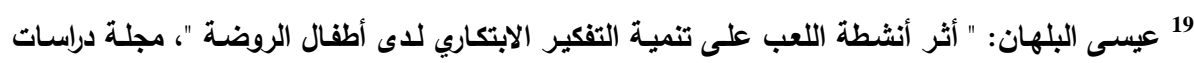

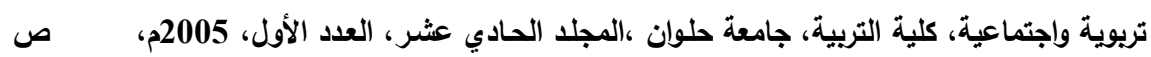

20 Gleason, T (2005): Mothers and Fathers Attitudes Regarding Pretend Play in the Context of Imaginary Companions and of Child Gender" Journal of Developmental Psychology, vol. 51, No. (4) pp. 412 -436 
مجلة كلية التربية، جامعة الأزهر، العلد: (164 الجزء الثالث) يوليو لسنة 2015م

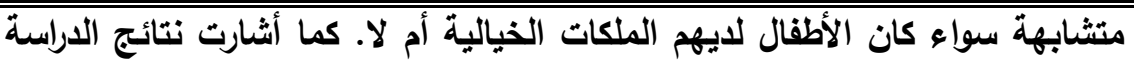

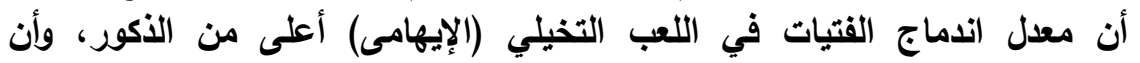
اتجاهات الأمهات نحو اللعب التظاهري أكثر ايجابية من اتجاهات الآباء.

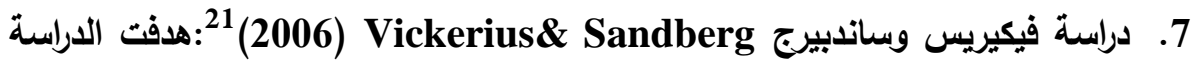

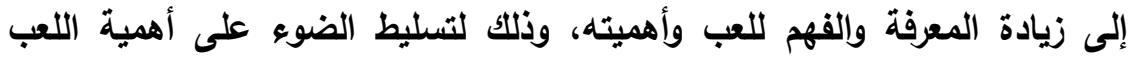

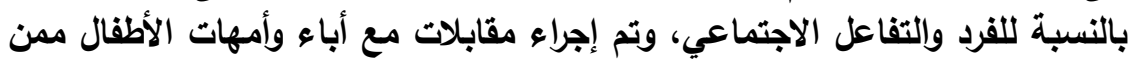

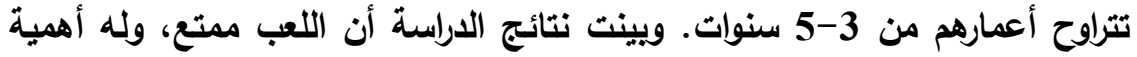

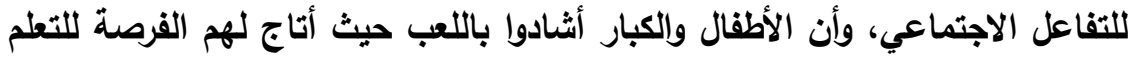

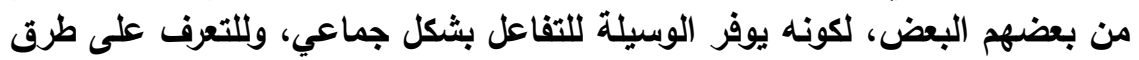
التفكير للآخرين أثناء اللعب.

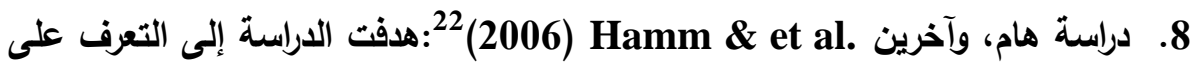

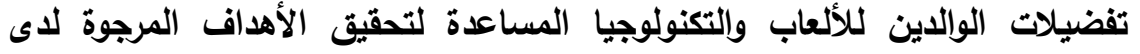

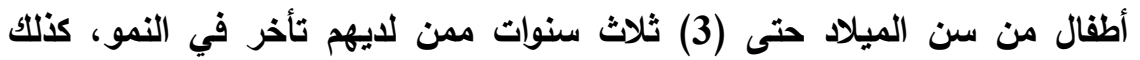

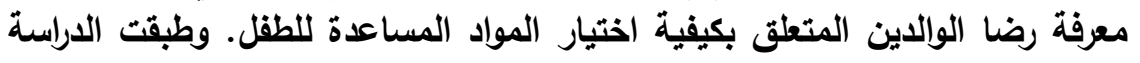

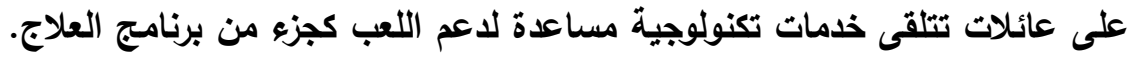

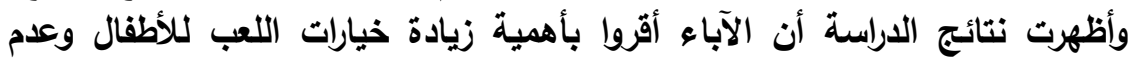

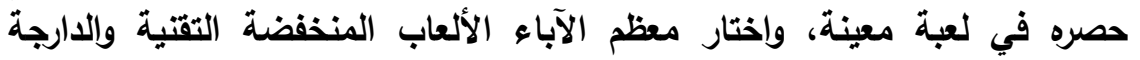

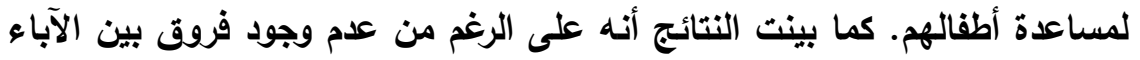

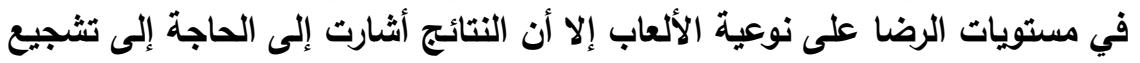

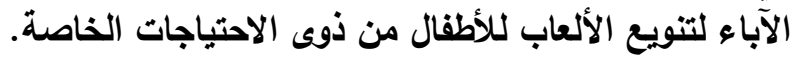

9. دراسة فريمان Freeman (2007):هدفت الاراسة إلى التعرف على معتقدات

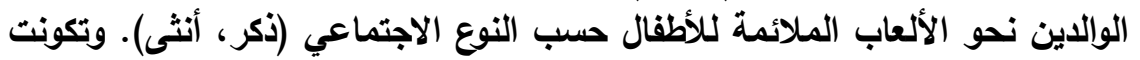

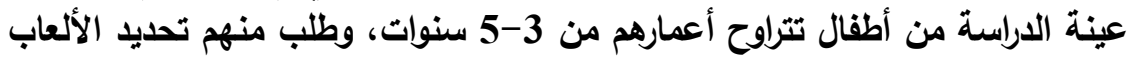

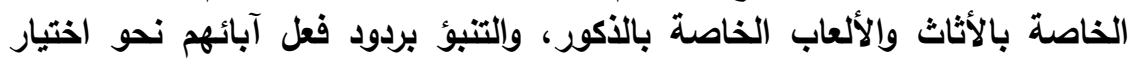

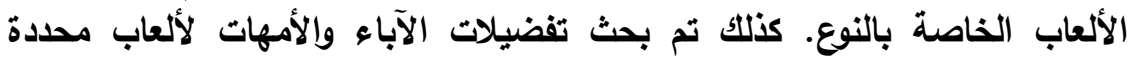

21 Vickerius, M. \& Sandberg, A.(2006): The Significance of Play and environment around play, Early Child Development and care, vol. 76, No.(2) pp.207-217.

${ }^{22}$ Hamm, E. M. et al. (2006): Play Outcomes and Satisfaction with Toys and Technology of Young Children with Special Needs, Journal of Special Education Technology ،vol. 21, No. (1) pp. 29-35

${ }^{23}$ Freeman,N. K. (2007): Preschoolers Perceptions of Gender Appropriate Toys and Their Parents Beliefs about Genderized Behaviors: Miscommunication, Mixed, Early Childhood Education Journal, vol. 34, No.(5) pp.357-366 


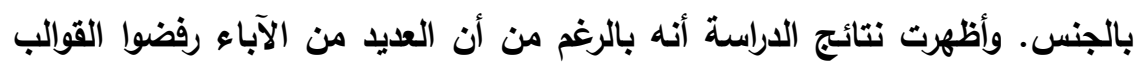

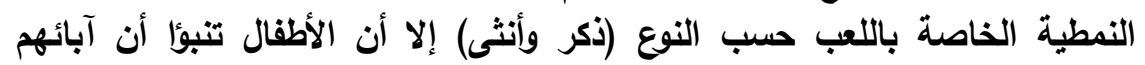

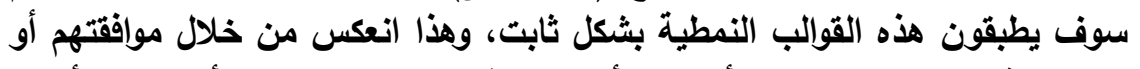

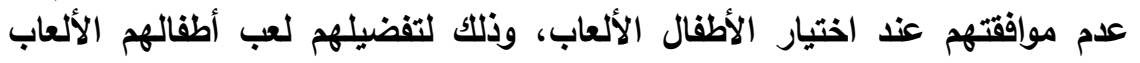
الخاصة بجنسهم.

10.دراسة نظمي أبو مصطفى، وعطاف أبو غالي (2009)

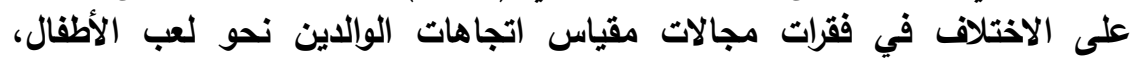

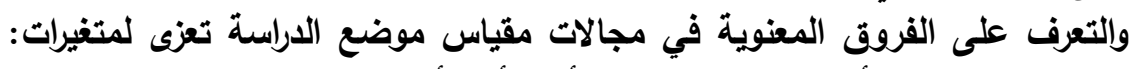

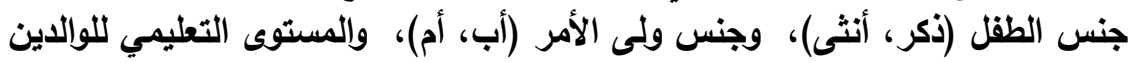

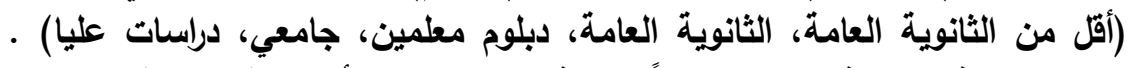

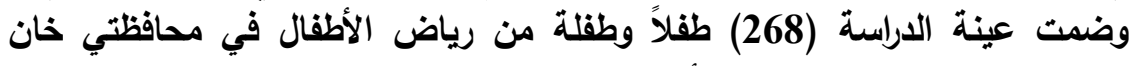

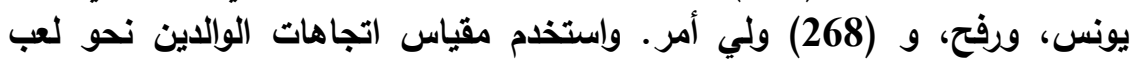

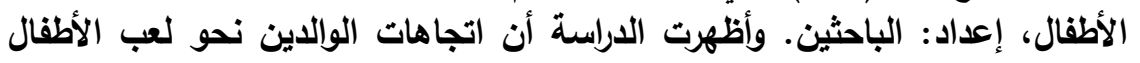

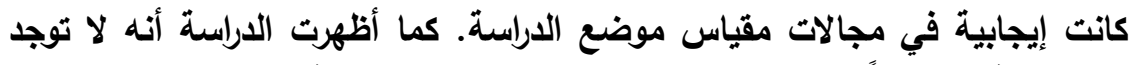

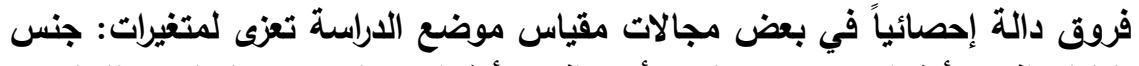

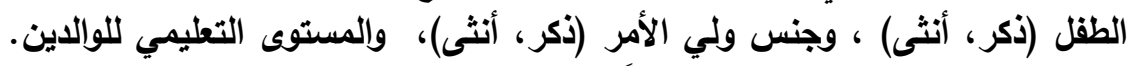

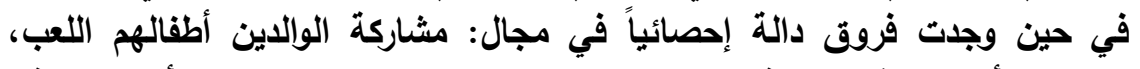

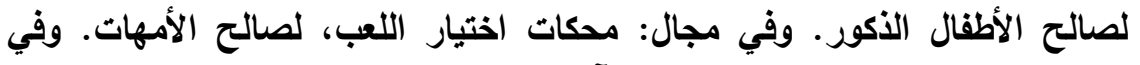

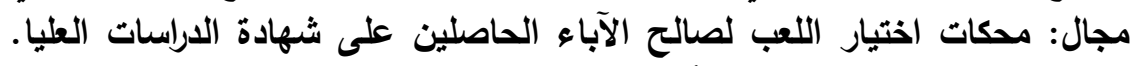

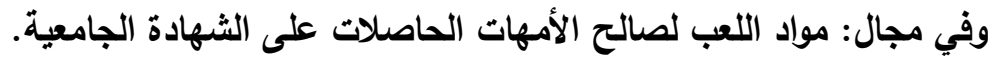

المحور الأول: الطفولة المفهوم والأهمية والخصائص مولب النهات

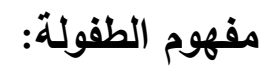

الطفل لغة: "من الفعل الثلاثي طقل، والطقل: هو النبات الرخص، والرخص

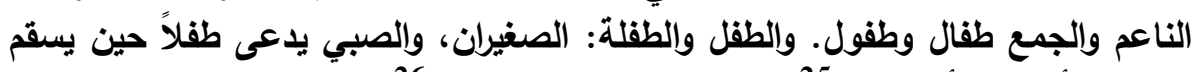

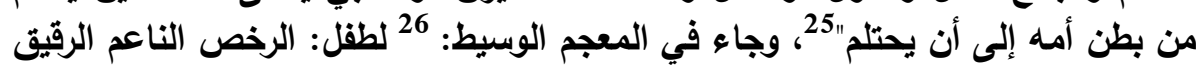

24 نظمي أبو مصطفى، وعطاف أبو غالي: اتجاهات الوالدين نحو لعب الأطفال" دراسة ميدانية على عينة

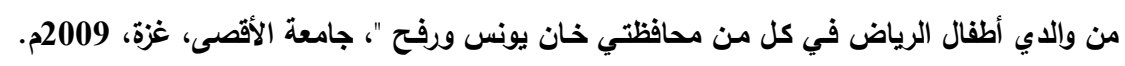

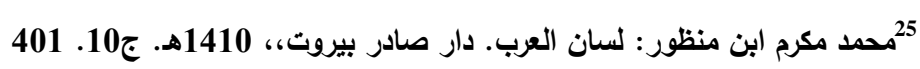

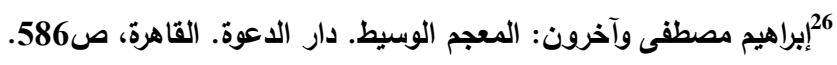

$$
\begin{aligned}
& \text {-546- }
\end{aligned}
$$




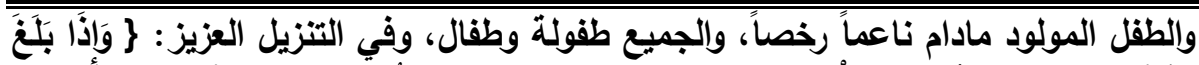

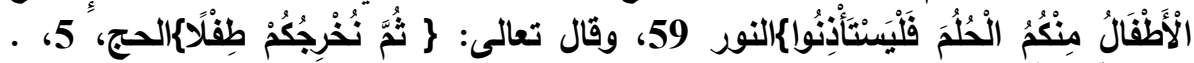

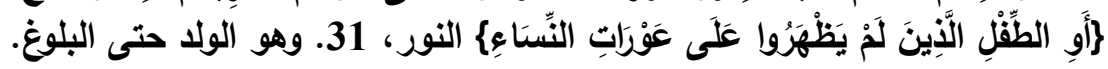

$$
\text { التعريف الاصطلاحي: }
$$

الطقل في التربية: يطلق على الولا والبنت حتى سن البلوغ البويعرف الثيبياني

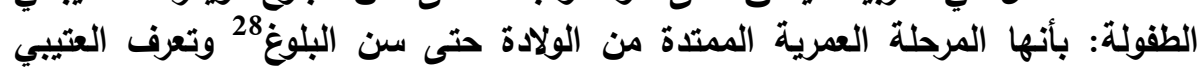

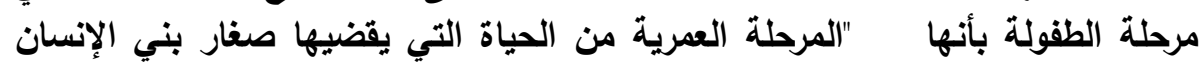

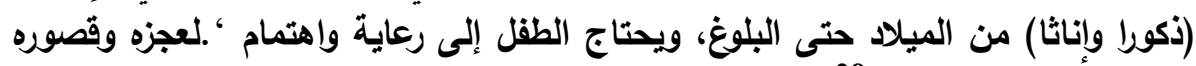

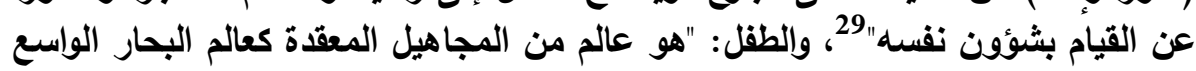

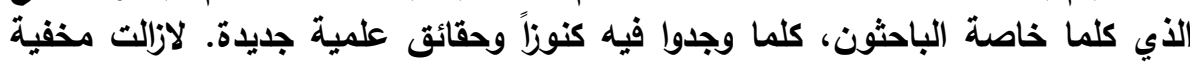

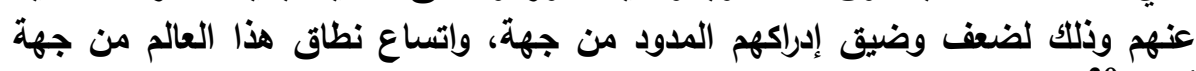

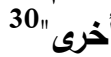

وتعرف الطفولة شرعا: كل مولود لم يصل سن البلوغ يعتبر طقلا ويقدر البلوغ

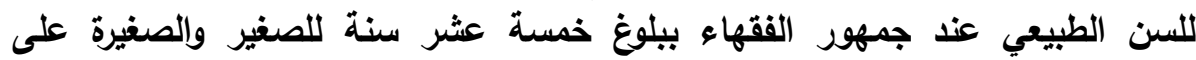

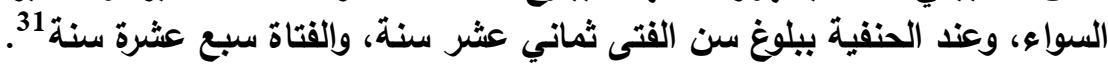

مدة الطقولة:

تعددت أقوال العلماء حول مدة مرحلة الطفولة فمن قائل:" الطفولة تمتل سنوات الطفات

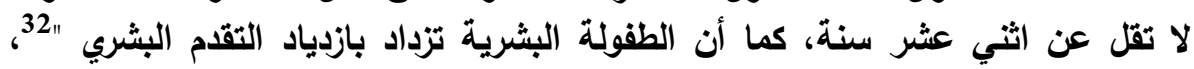

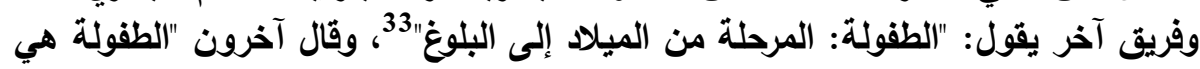

27 طسن شحاتة وآخرون: معجم المصطحات التزبوية والنفسية. الدار المصرية اللبنانية. القاهرة. 1414،

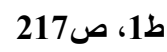

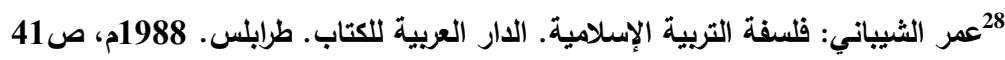
29 فاطمة فرج العتيبي: حقوق الطفل ورعايته في الإسلام وفي السويد. رسالة ماجستير . جامعة أم القرى.

30 3مد عبد الله: بناء الأسرة الفاضلة. دار البيان العببي. بيروت. 1410. ص94.

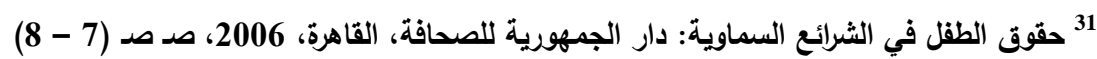

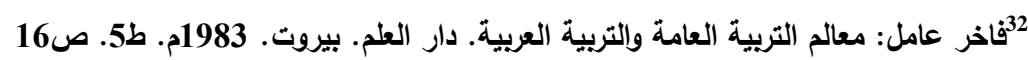

333 
المرحلة التي تبدأ بعد سن الثانية، أي بعد مرحلة الرضع وتستمر حتى سن الثانية عشرة.

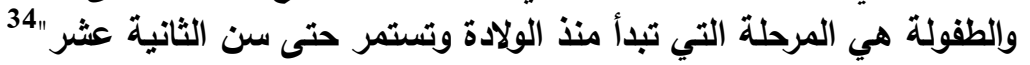

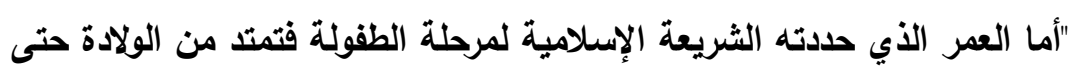

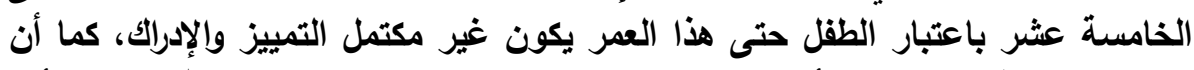

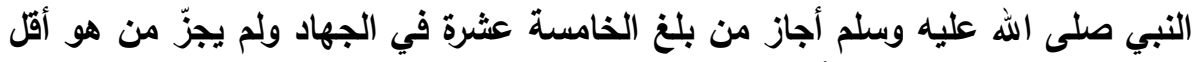
من ذلك وهذا دليل على أن بلوغ الخامسة عشرة هو نهاية الطقولة ويداية الثباب

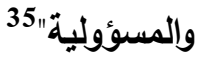

"ومرحلة الطقولة من أهم مراحل التكوين ونمو الثخصية، وهي مجال إعداد الداد

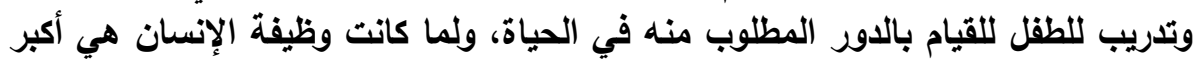

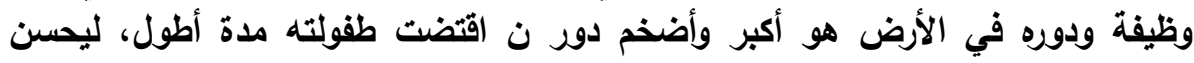

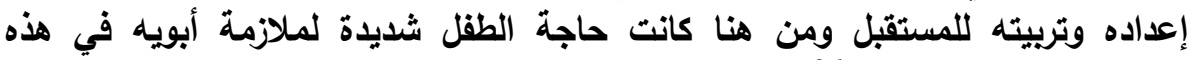

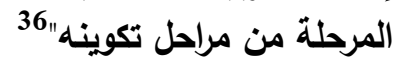

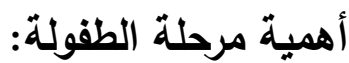

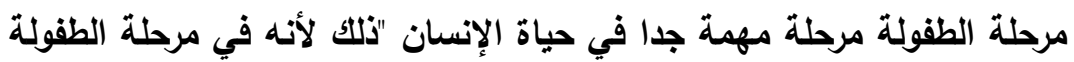

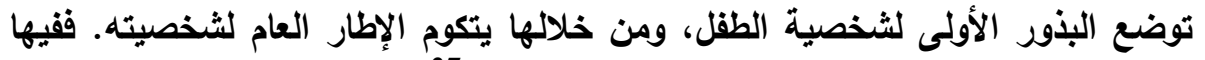

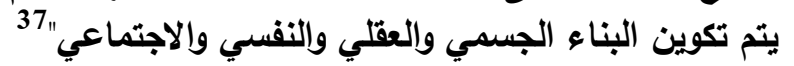

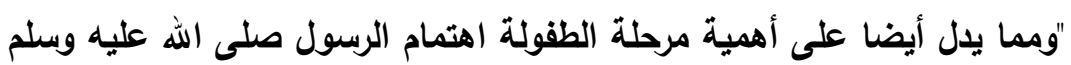

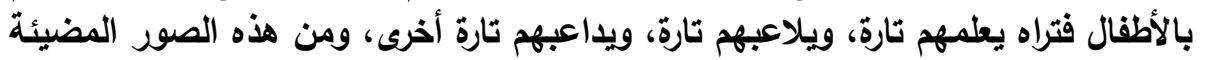

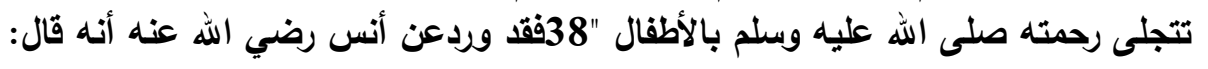

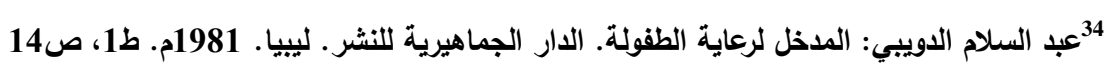
35 3نة متخصصة: هموم الطفل العربي في المدينة العربية، ضمن سلسلة الطفل الطية العربي، الإسكندرية.

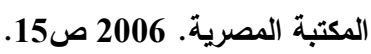

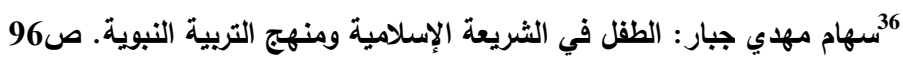
137 محمد صالح العلوي: خطاب النبي صلى الله عليه وسلم للطفل المسلم وتطبيقاته التربوية. رسالة

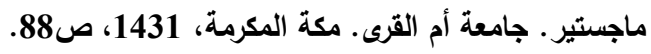
38 محمد صالح العلوي: خطاب النبي صلى الله عليه وسلم للطفل المسلم وتطبيقاته التربوية. رسالة

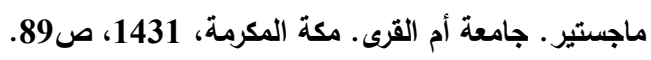


مجلة كلية التربية، جامعة الأزهر، العلد: (164 الجزء الثاثث) يوليو لسنة 2015م

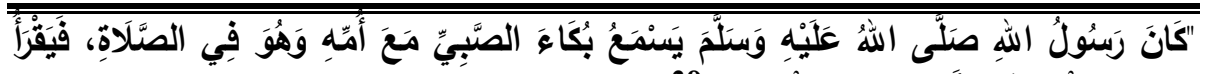

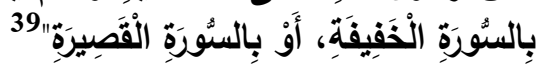

كما جاءت صور من حرص السلف على تربية الطقل, وهذا مما يدل على أهمية هذه المرحلة عند السلف:

فمعاوية بن أبي سفيان رضي الله عنه كان يجل البنات الصغيرات ويحبهن، فقل

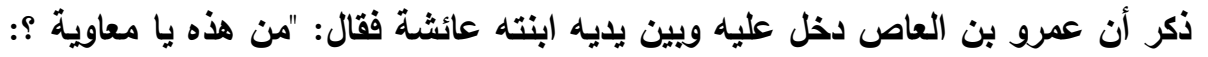

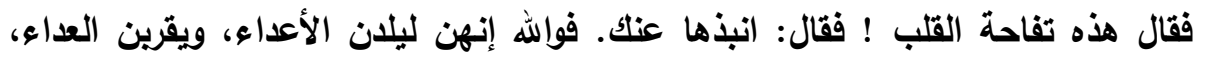

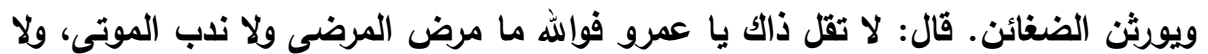

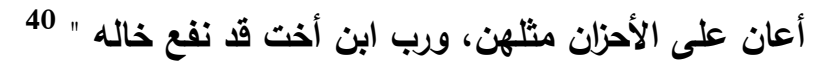

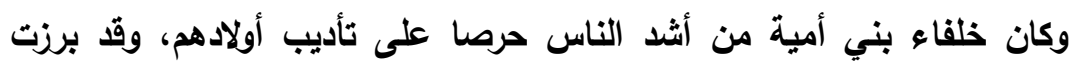

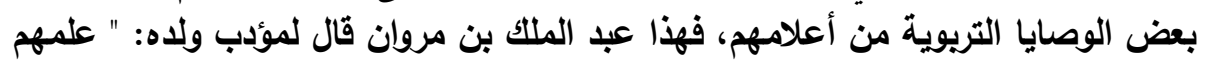

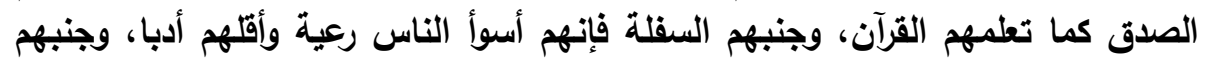

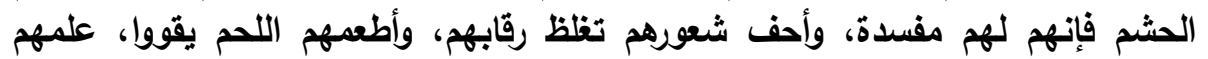

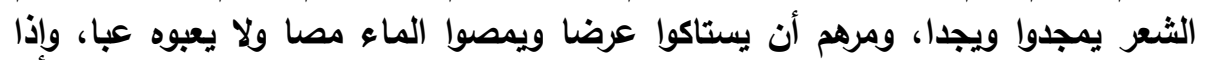
احتجت إلى أن تتناولهه بأدب فليكن ذلك في ستر لا يعلم به احد من الغاشية فيهونوا

ولتأكيا أهمية هذه المرحلة من عمر الإنسان، نجد إثراء المفكرين المسلمين

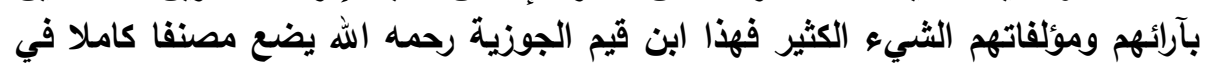

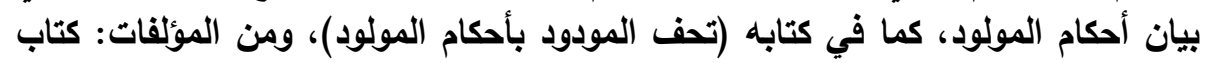

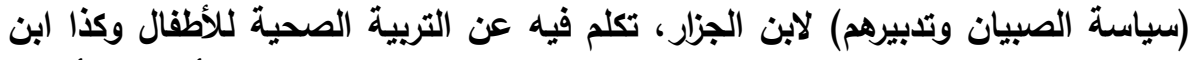

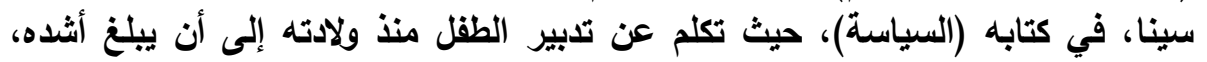

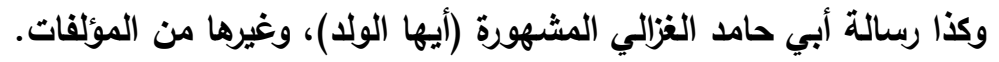

لقد حرصت التربية الإسلامية على هذا كله " لأن الأطفال هم عماد الأمة، وأملها

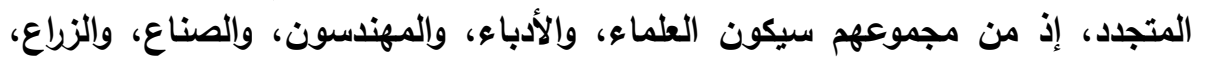
ورجال الفكر والسياسة، وأصحاب القرار في المجتمع، فهم بالجملة القوة البشرية التي واعني

393سلم بن الحجاج أبو الحسن القشيري النيسابوري: صحيح مسلم، دار إحياء التراث. بيروت ج1اص342. 40 أحمد بن محمد ابن عبد ريه الأندلسي: العقد الفريد، تحقيق مفيد محمد قميحة، دار الكتب العلمية،

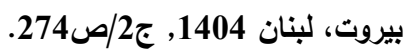

41 عبد الله بن مسلم ابن قتية: عيون الأخبار، دار الكتب العلمية، بيروت، لبنان، باب وصايا المعلمين،

$$
\text { (د) }
$$


سيكون على أكتافها بناء المستقبل الحضاري للأمة في مختلف نواحي الحياة، فبقدر ما الأياء

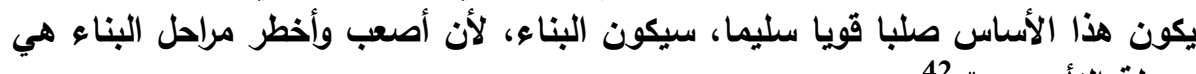
مرحلة التأسيس " 42

وخلاصة ما سبق فأهمية مرحلة الطفولة تتبع من عدة جوانب: 43 الأول: طول هذه المرحلة عند جنس البشر:

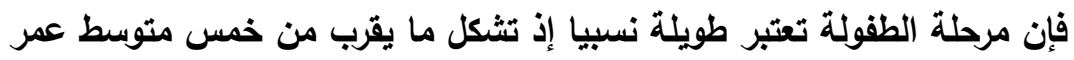

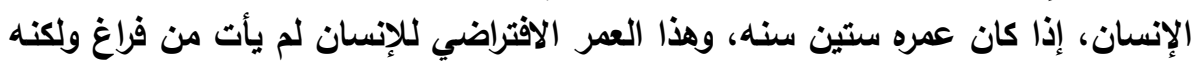

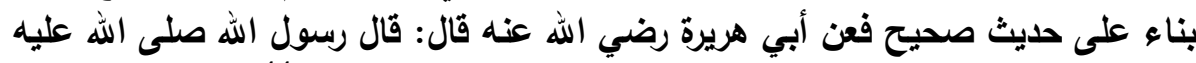

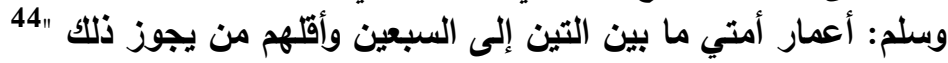

الثاني: قابلية هذه المرحلة للتكوين والتوجيه والبناء: إن مرحلة الطقولة من أخصب المراحل العمرية للإنسان يمكن للمربي من خلالها

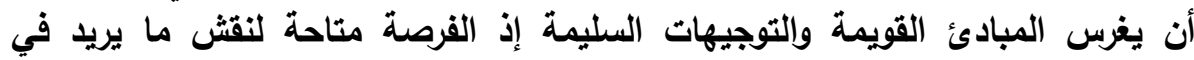

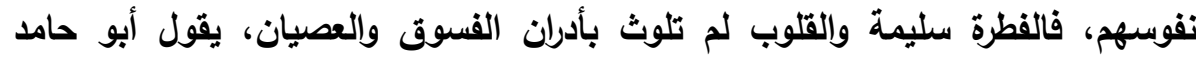

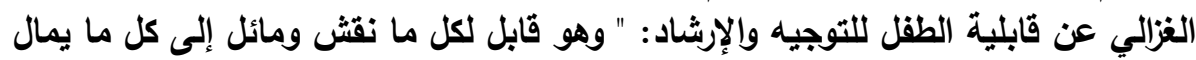
به إليله، فإن عود الخير وعلمه نشأ عليه وسعد في الانيا والآخرة " 45 الثالث: النسبة العالية لعدد الأطفال بين السكان:

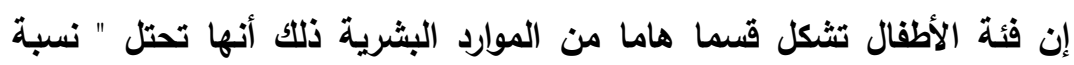

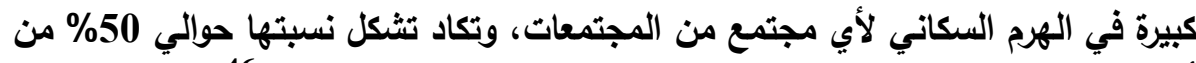

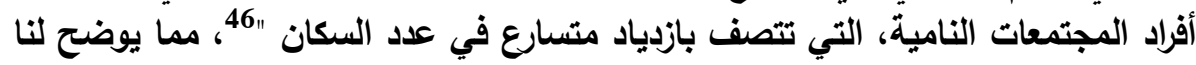
42, حسين عبد الله بانبيلة: أصول التربية الوقائية للطقولة في الإسلام، رسالة دكتوراه، جامعة الإمام محمد

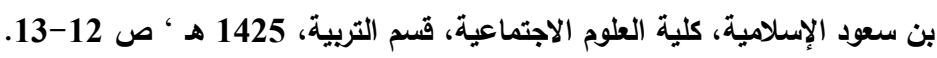
43 محد صالح العلوي: خطاب النبي صلى الله عليه وسلم للطفل المسلم وتطبيقاته التربية.

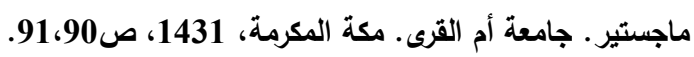

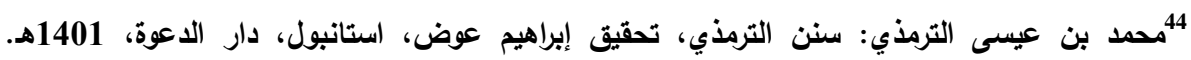
ص806، حديث رقم 3551

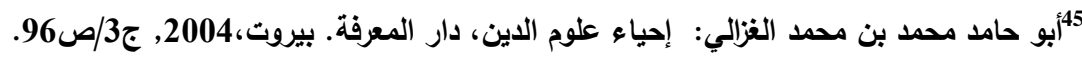

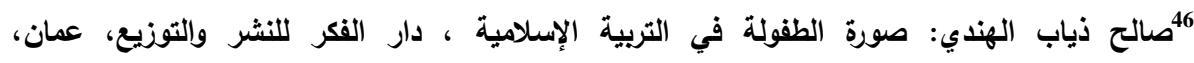
الأردن، 1990م, ص9 
مجلة كلية التربية، جامعة الأزهر، العدد: (164 الجزء الثالث) يوليو لسنة 2015م

أهمية هذه المرحلة وعظيم دور المربين في إعدادها الإعداد الصحيح الذي يجعلها قادرة على العطاء والإنتاج بشكل فاعل وعل في المستقبل.

إن ما سبق يؤكد أهمية مرحلة الطفولة، ويمكن القول حينئذ " إن أية محاولة

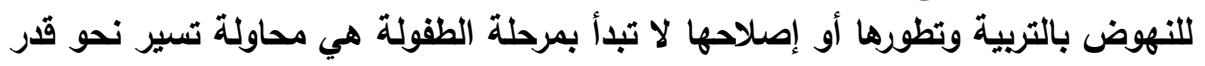

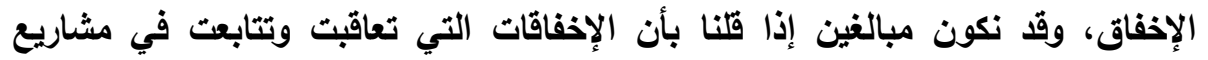

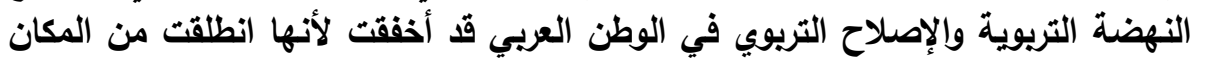

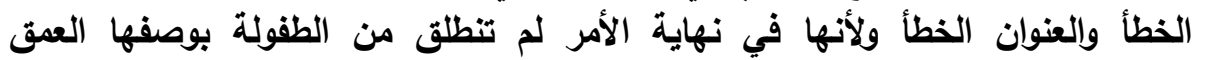

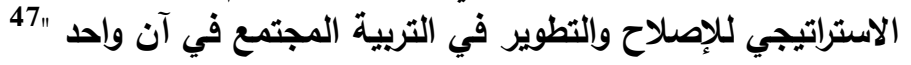
مراحل الطفولة: - م

الطفولة هي المرحلة المبكرة من حياة الإنسان والتي يتثكل خلالها ككائن اجتماعي

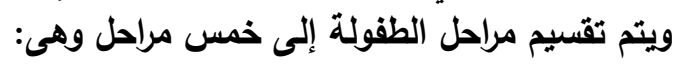
1- الطقل حليث الولادة THE NEW BORN, IN FANT وهى أقصر فترة من فن فئم فترات النمو خلال الحياة وتبدأ من لحظة الميلاد إلى فترة أسبوعين. 2- مرحلة الرضاعة BABY HOODوتبدأ بعد أسبوعين من عمر الطفل وتمتا حتى نهاية السنة الثانية من عمره. 3- مرحلة الطفولة المتأخرة EARLY CHILD HOOD وتبدأ من سن عامين إلى

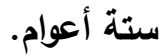

4 - مرحلة الطفولة المتأخرة 5 اوتبدأ من 5 إلى 12 سنة 48 اعلى 5- طور البلوغ الحلم: وتثمل بداية واكتمال التغييرات الجسمية المرتبطة بالبلوغ الجنسي

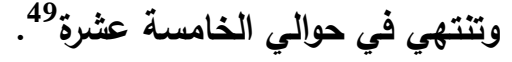
خصائص نمو الطقل: - 20

77 $4{ }^{7}$

$$
\text { والتتوزيع، 1425هـ. }
$$

48 خيرى خليل الجميلى، بدر الدين كمال عبده: الدذخل في "الممارسة المهنية في مجال الأسرة والطفولة"،

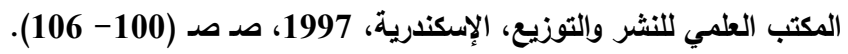

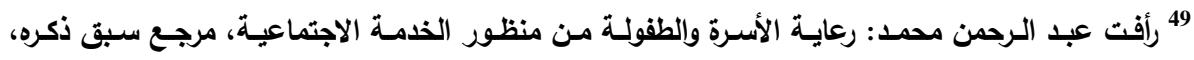
ص(122). 
على الرغم من الاختلافات التي ترجع إلى البيئة الجغرافية والظروف المعيشية

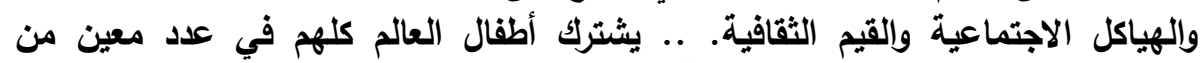

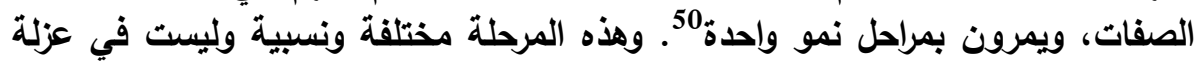

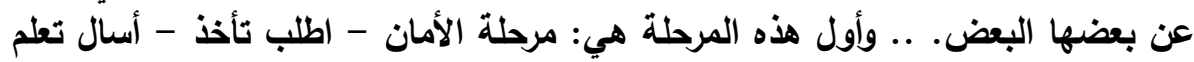

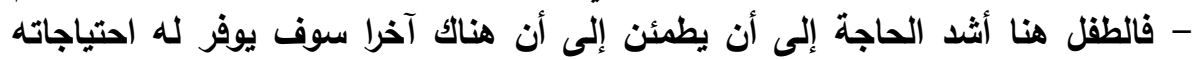

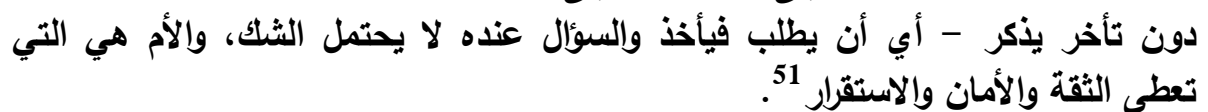

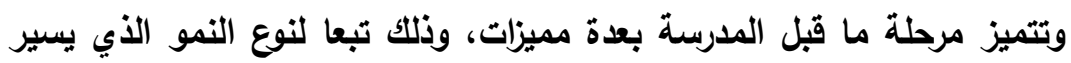

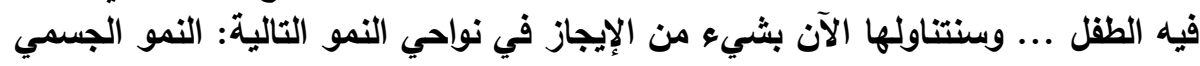

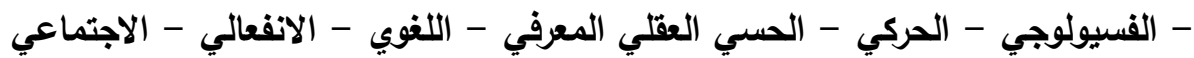

يتضمن النمو الجسمي التغير التشريحي كما وكيفا وحجما وشكلا ونسيجا فقيه

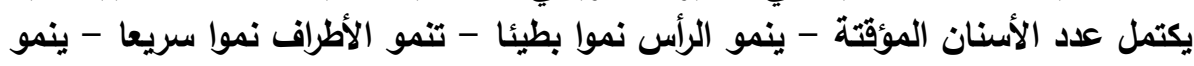

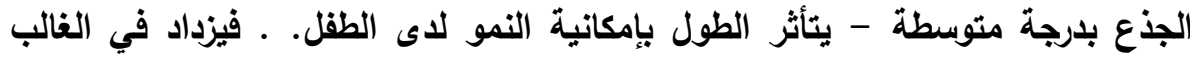

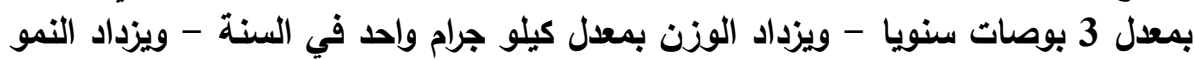

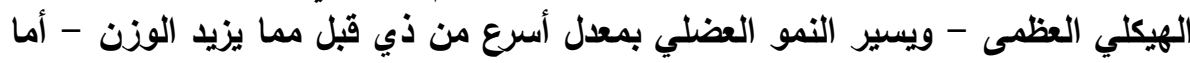

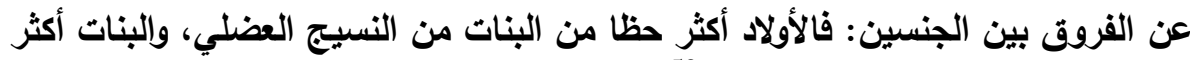

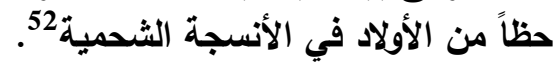

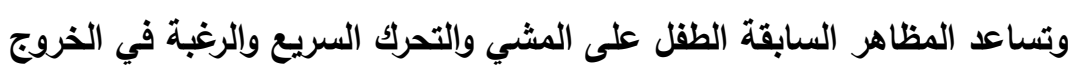

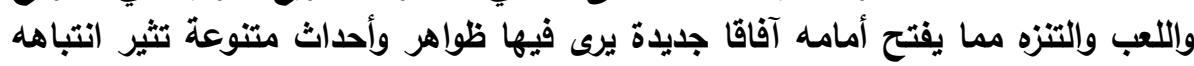
وتجعله يوجه الأسئلة للكبار من حوليه.

50 هـى ديوزايد: الأطفال الأقل من ست سنوات. القاهرة: رسالة اليونسكو. العدد 204-10 يوليو 1978 ص .6 51 محمد شعلان: الاضطرابات النفسية في الأطفال. الجزء الأول. القاهرة: الجهاز المركزي للكتب الجامعية

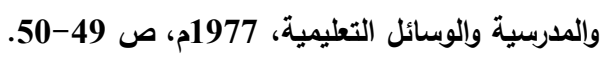

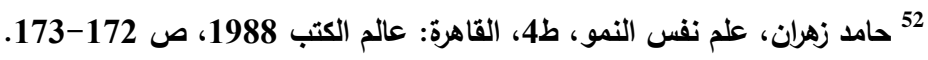




\section{2-النمو الفسيولوجي:}

يطرد نمو أجهزة الجسم المختلفة ووظائفها في هذه المرحلة بثكل ملحوظ، المبل

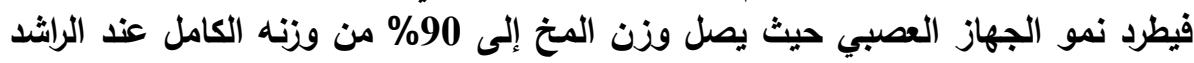

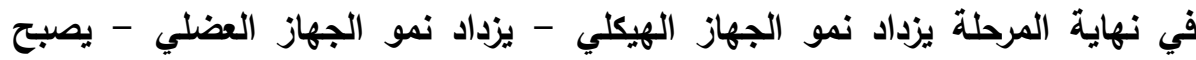
التنفس أكثر عمقا وأبطأ من ذي قبل - فئل فيالتدريج يقل مقدار النوم حتى يصل إلى 10 ساعات تقريباً ليلاً 53.

وهكذا يساعد نمو المخ والجهاز العصبي على تنشيط ذهن الطفل ويجعله يفكر

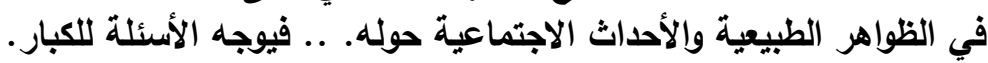

$$
\text { 3-النمو الحركي: 20 - 20 }
$$

تعتبر هذه المرحلة مرحلة النشاط الحركي المستمر، وتمتاز حركات الطقل هنا

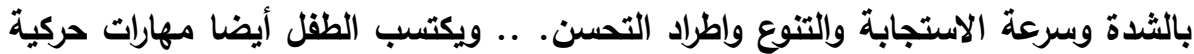

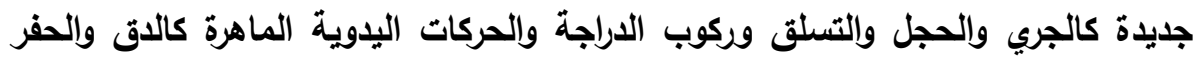

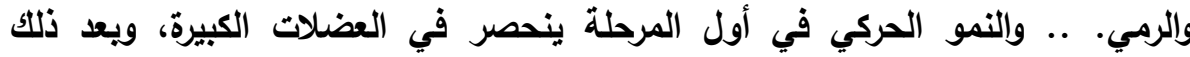

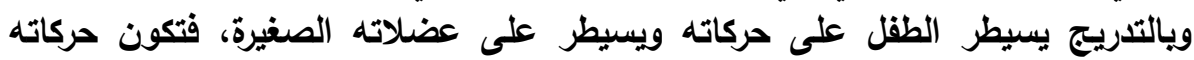
ضعيفة قد ازدادت نموا واستقلالاً 54. والطقل في هذه الفترة بوجه عام يتصف بكثرة الحركة والنشاط والرغبة في اللعب

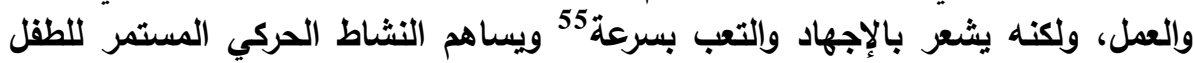

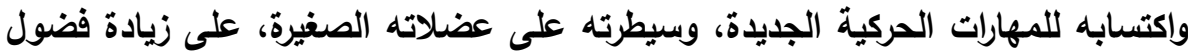

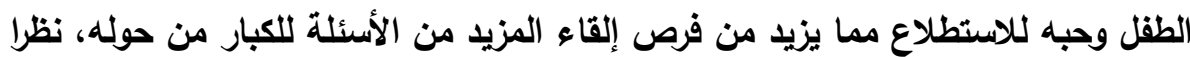

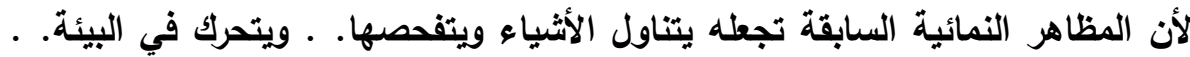

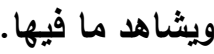
4-النمو الحسي:

الإدراك الحسي وسيلة الطقل الأولى للاتصال بنفسه ويبيئته ولقهم مظاهر الحياة المحيطة به وتكوين حياته المعرفية الواسعة. . ولذا يعتبر أساس حياة الطائه الطقل المعرفية،

$$
\begin{aligned}
& \text { 53 المرجع السابق، ص } 53 \\
& 54 \text { المرجع سابق، ص المرجي، صن } 177 . \\
& 55 \text { هدى برادة، وفاروق صادق: علم نفس النمو مرجع سابق ص 98-99. } \\
& -553-
\end{aligned}
$$


وتتأثر عملية الإدراك بيئة الطقل 56.

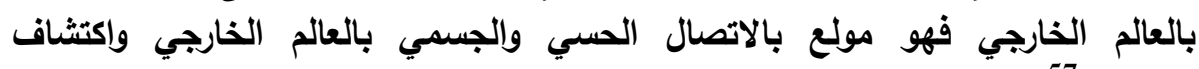
محتوياته 57.

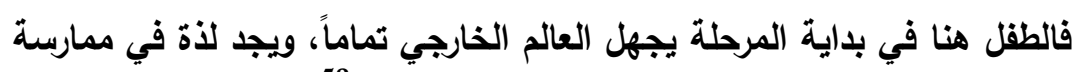

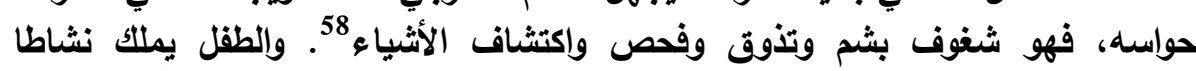

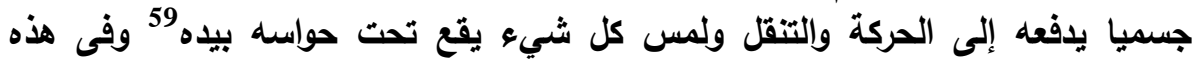

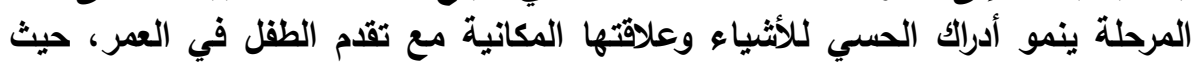

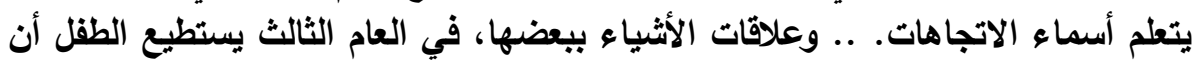

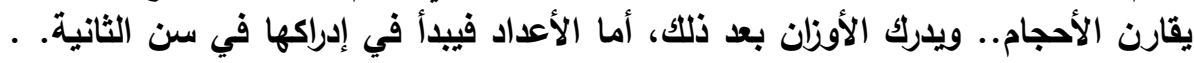

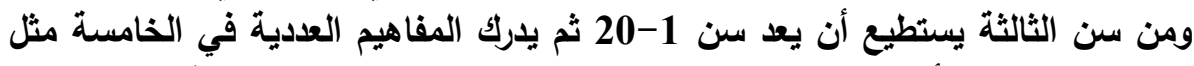

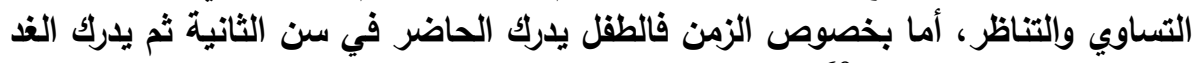

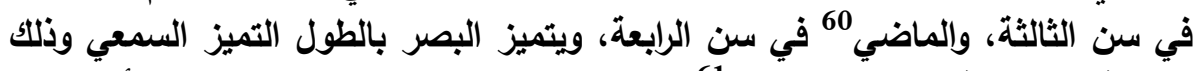

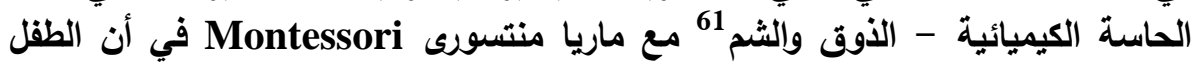

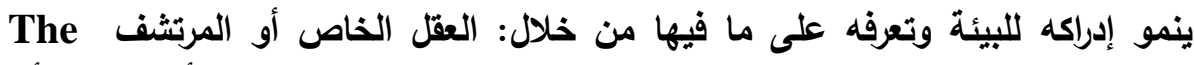
Absorbent Mind يلمسها الطقل ويتعرف عليها بحواسه.

ولا شك أن النمو الحسي للطقل بالصورة السابقة يثير انتباه الطقل نحو ظواهر

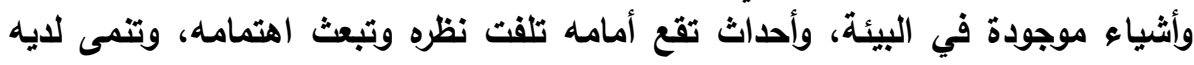

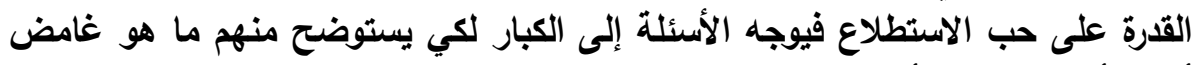
أمامه أو مثير لقلقه أو استغرابه. 5-النمو العقلي المعرفي:

56 هلى برادة. وآخرون: في سيكولوجية النمو القاهرة: مذكرات غير منشورة كلية التربية جامعة عين

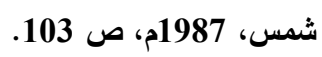
57 عبد الحميد الهاشمي:: علم نفس التكويني. أسسه وتطبيقه. من الولادة إلى الثيخوخة (ط4) جدة: دار

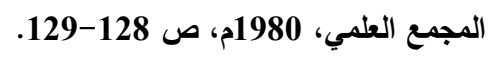

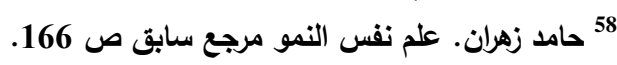

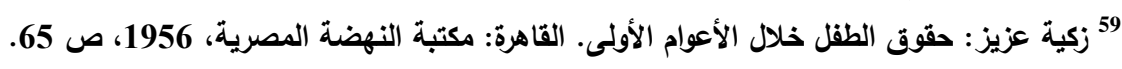

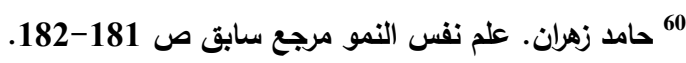

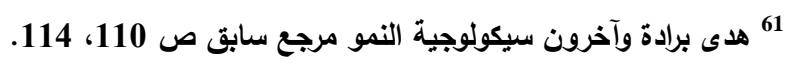




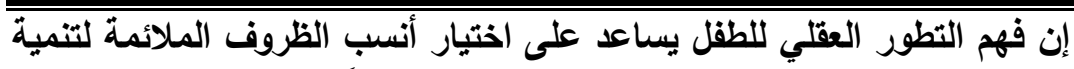

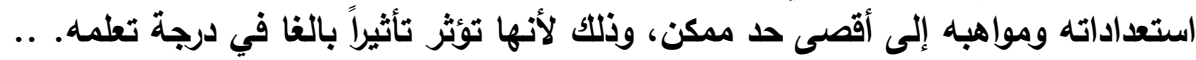

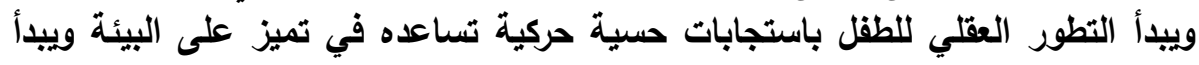

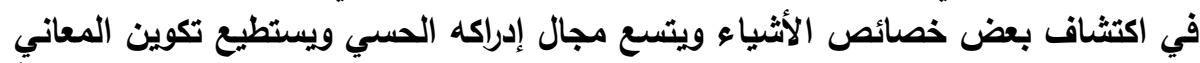
Conceptualization

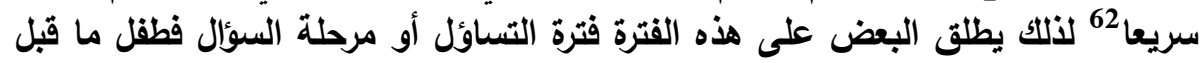

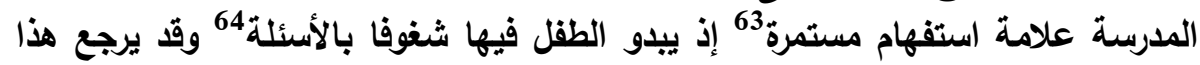

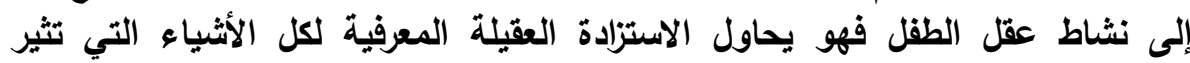

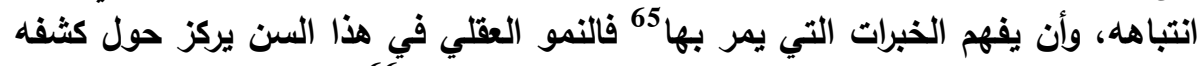

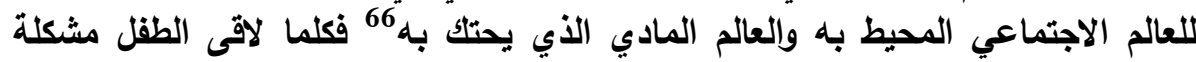

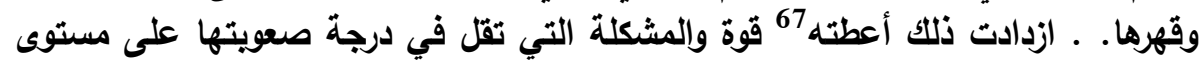

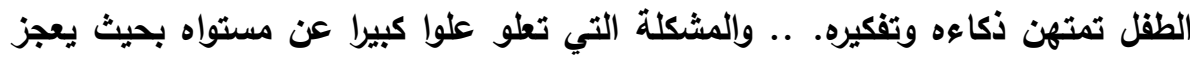

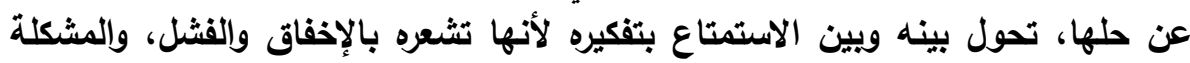

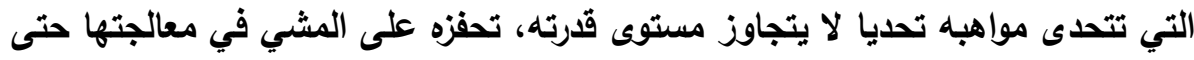

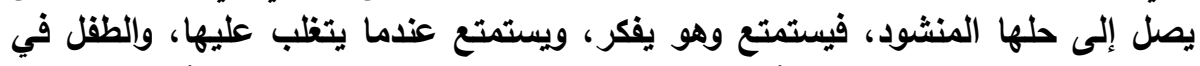

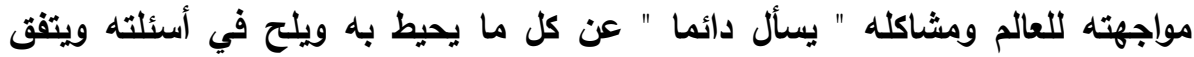
موجلاس مكنالى Mc Nally مع تقسيم جان بياجيه Piaget مظاهر النمو العقلي إلى:

- - مenseory motor period من المرحلة الحسية الميلا إلى الثانية من العمر.

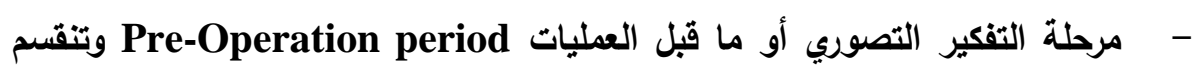
إلى طورين:

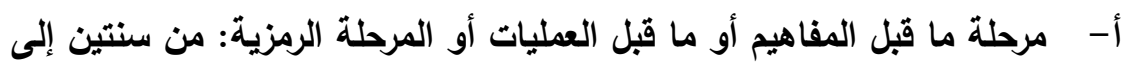

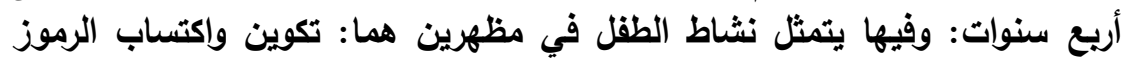

62 فؤاد البهي السيد: الجداول الإحصائية لعلم النفس والعلوم الإنسانية الأخرى. القاهرة: دار الفكر العربي، 1958م، ص 184

63 فوزية دياب: نمو الطقل وتنشئته بين الأسرة ودور الحضانة (ط.3). القاهرة: مكتبة النهضة المصرية.

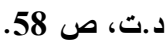
64 أحمد زكى صالح: علم النفس التربوي (ط.138). القاهرة: مكتبة النهضة المصرية، 1979م.

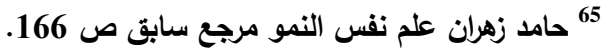

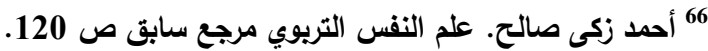

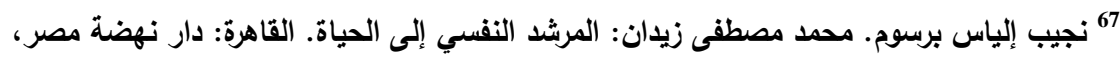
1965م، ص 98 
اللغوية والرموز العقلية التي تساعده على استدخال الأشياء والتعبير عنها

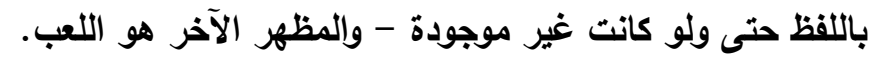

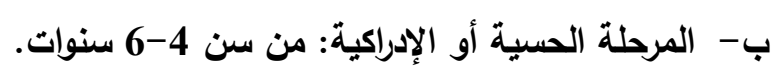

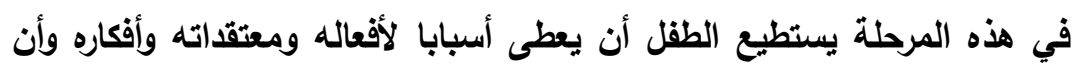

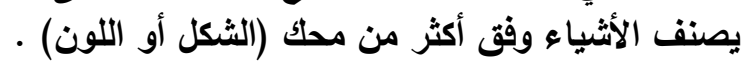

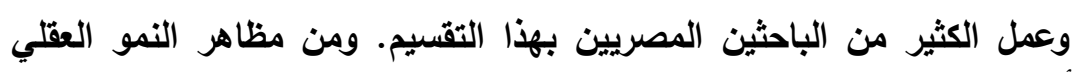

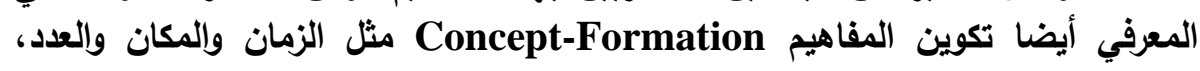

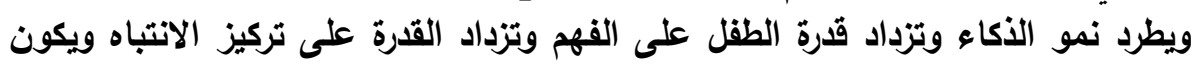

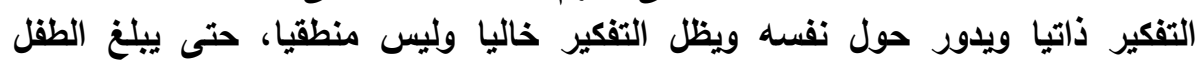

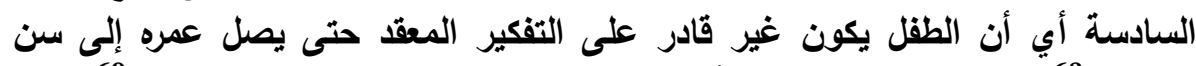

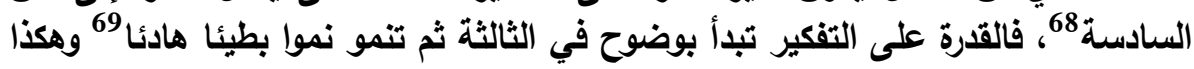

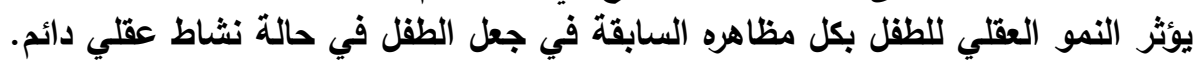

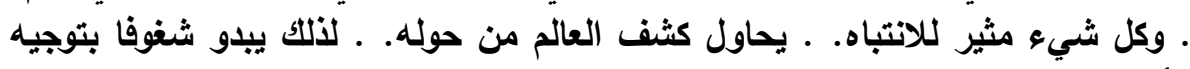

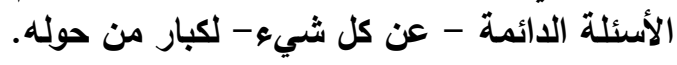

6-الكلام والنمو اللغوي:

الكلام هو الوسيلة التي يتصل بها الإنسان ببيئته ليعبر عن أفكاره ورغباته

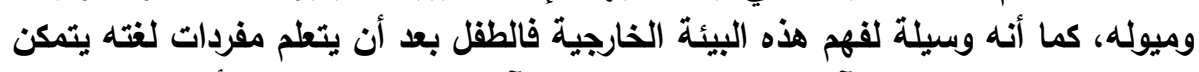

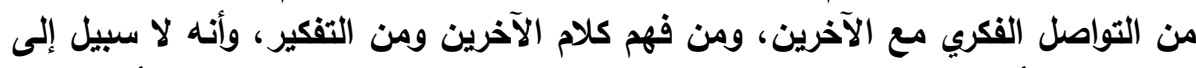

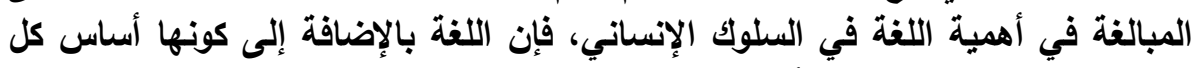

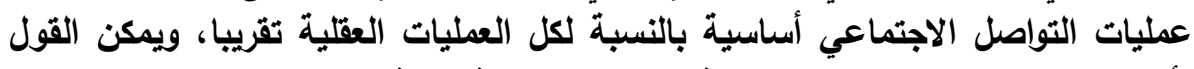

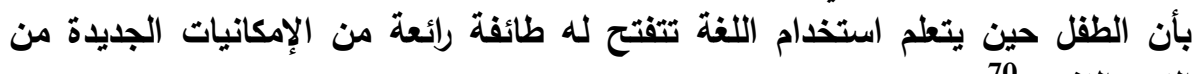
النمو النفسي النفل هين صورة نمو الكلام لاى الطفل: وتأخذ أريع مراحل هي:

68 68 حامد زهلان علم نفس النمو مرجع سابق ص 18-185. 99 فؤاد البهي السيد: الأسس النفسية للنمو من الطفولة إلى الثيخوخة القاهرة: دار الفكر العربي، 185 1974م.

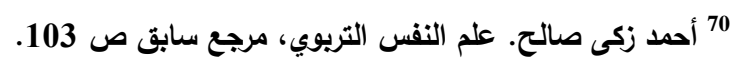
-556- 
مجلة كلية التربية، جامعة الأزهر، العدد: (164 الجزء الثالث) يوليو لسنة 2015م

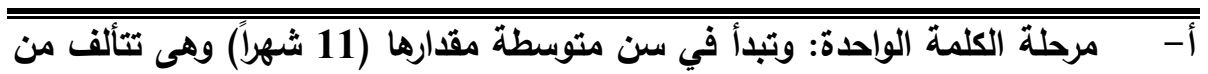

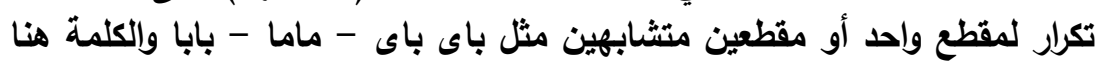

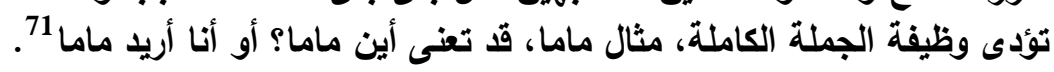

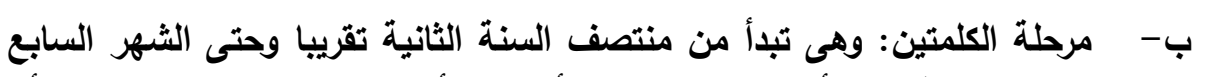

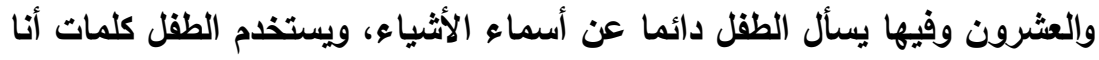

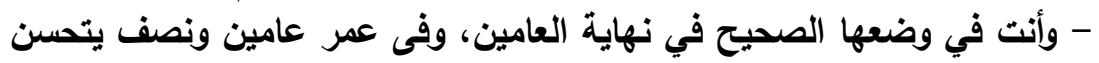

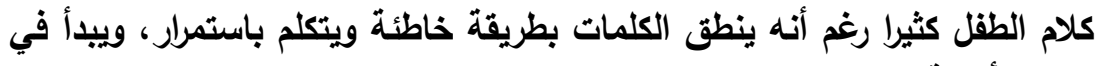

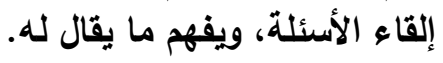

ج- - مرحلة الجملة القصيرة: وهى تستمر من نهاية المرحلة السابقة وحتى السنة الرابعة، وهنا يتكلم الطفل بأسلوب مفهوم، ويلقى الكثير من الأسئلة.

دـ - مرحلة الجملة الكاملة: وهى تقع أثناء السنة الرابعة وقوامها (5) كلمات والجملة

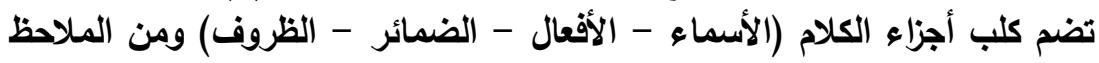

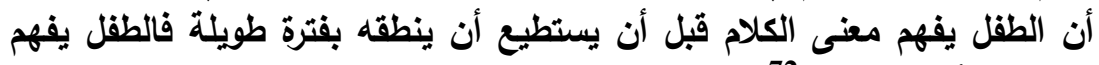

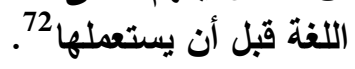

خصائص لغة الطقل: - خ

أ- يغلب عليها التعلق بالمحسوسات لا المجرادات.

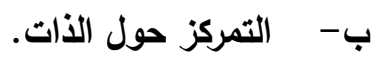
ج- السذاجة وعدم الدقة.

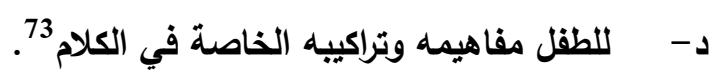

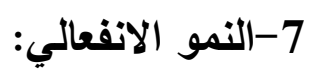

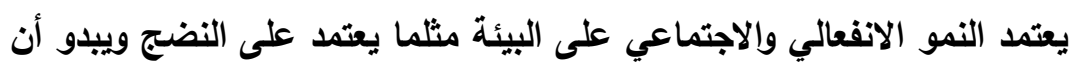

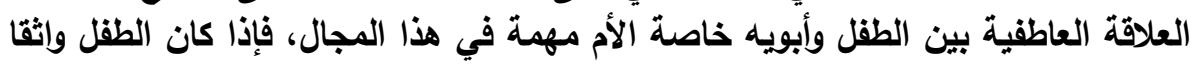

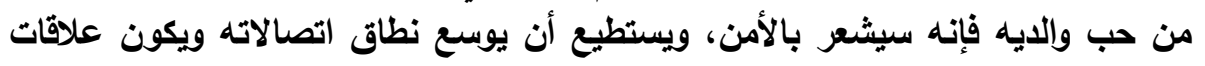

71 هنري فالون، أصول التفكير عذد الطفل، ترجمة محمد القصاص، محمود قاسم، ج2، القاهرة: مكتبة

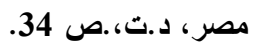
72 حامد زهان. علم نفس النمو مرجع سابق ص 189.

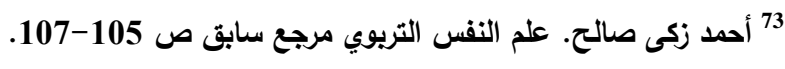


مع الآخرين 74 ومن أبرز مظاهر النمو الانفعالي في هذه المرحلة الثعور بالقلق والخوف، وما ينتاب الطفل من نويات غضب وإِ وإحساس بالغيرة.

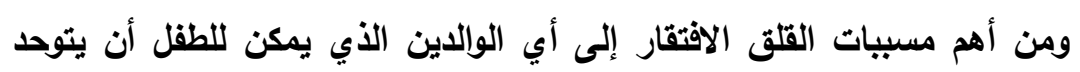

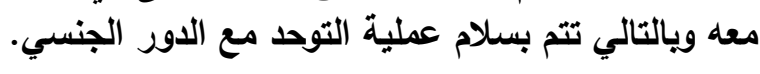

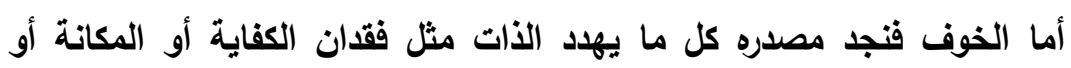
الفشل هي عمل أو تعرض الطقل للسخرية من جانب الآخرين.

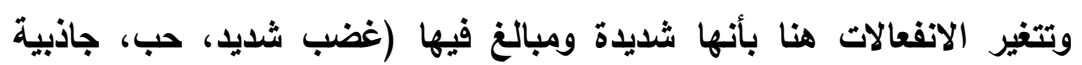

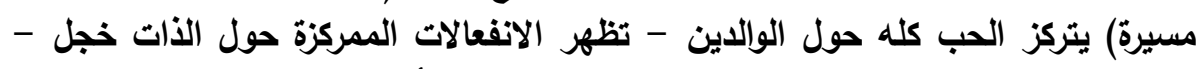

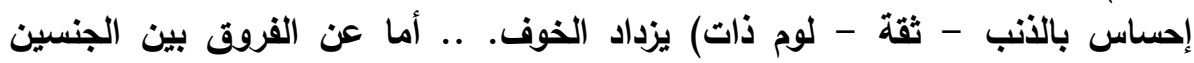

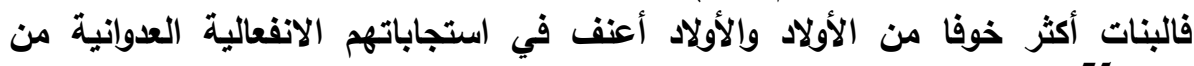

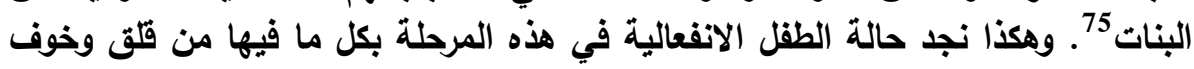

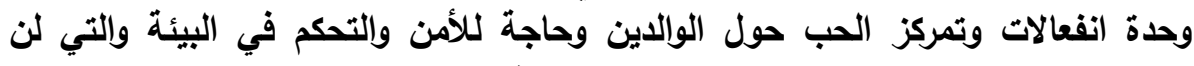

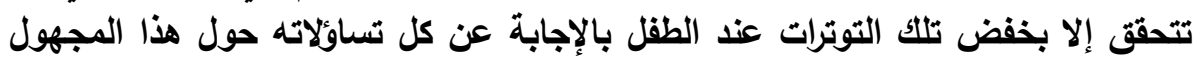
الأي يهدد كيانه.

$$
\text { 8-النمو الاجتماعي: }
$$

تعتبر السنوات الأولى من حياة الطفل مهمة في تثكيل شخصيته الاجتماعية

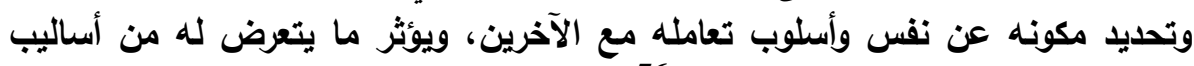

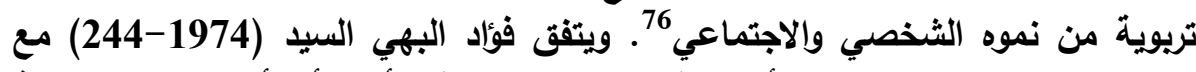

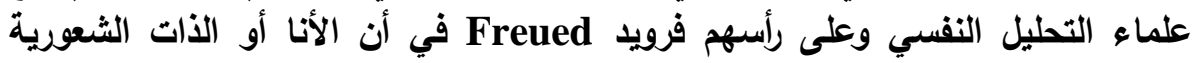
مركب اجتماعي يكتسبه الطقل من علاقته ببيئته الاجتماعية وإلمادية وأن الضمائ ألمير أو أو الأنا

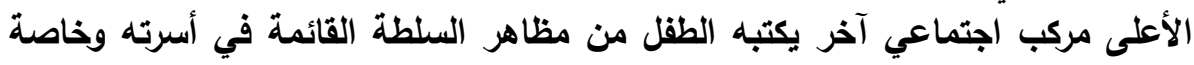

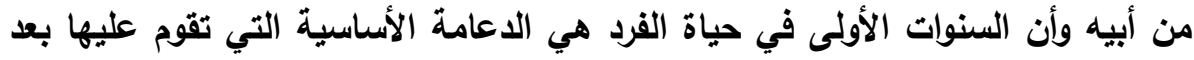

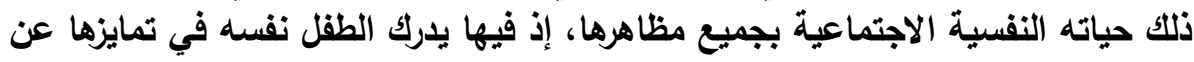

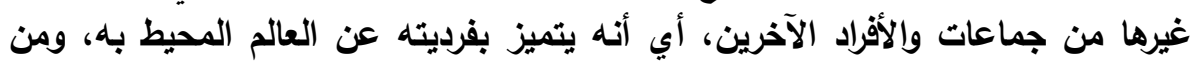

74 محمد حمزة الأهل: سيكولوجية ميول الأطفال القرائية. بغداد دائرة الثئون الثقافية والنشر، 1984م، ص

75 حامد زهلان علم نفس النمو مرجع سابق ص 195.

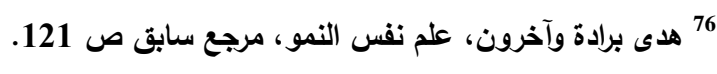


مجلة كلية التربية، جامعة الأزهر، العلد: (164 الجزء الثالث) يوليو لسنة 2015م

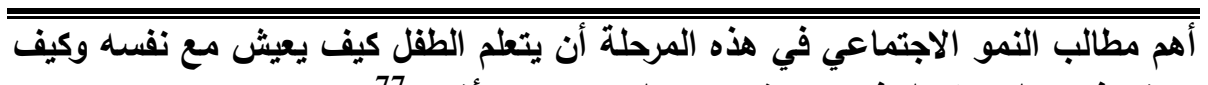

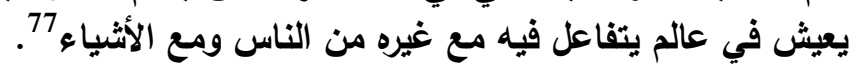

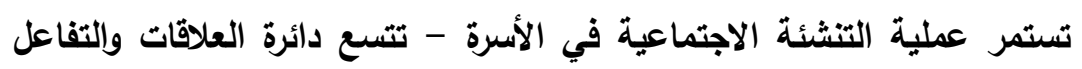

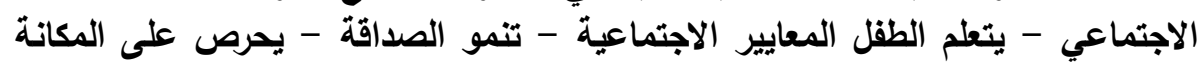

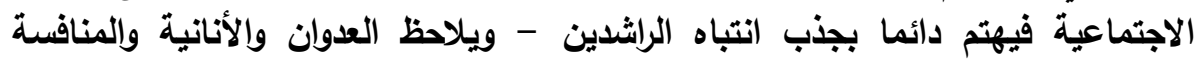

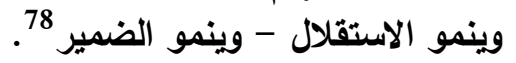

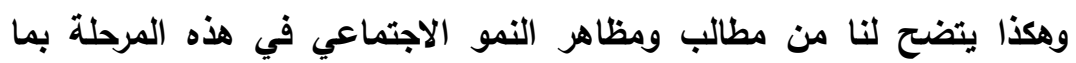

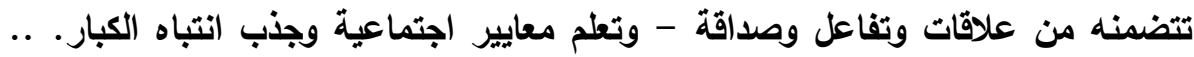

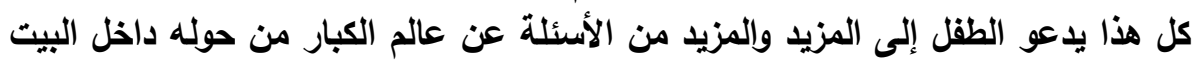

$$
\text { وخارجه. }
$$

9-النمو الجنسي: 9 9 9 - 9

يثاهد الفضول وحب الاستطلاع الجنسي، حيث يصبح الاهتمام الجنسي مركزا

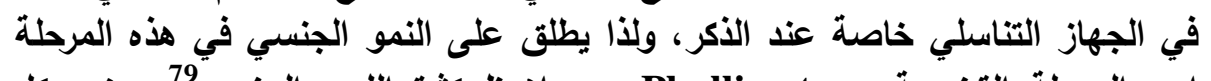

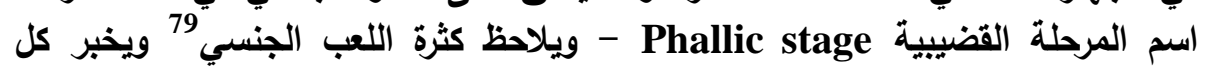

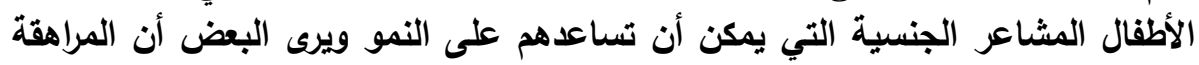

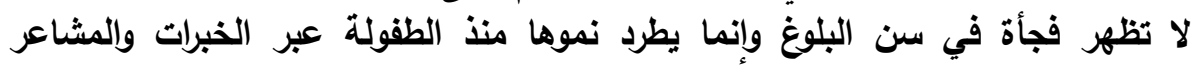

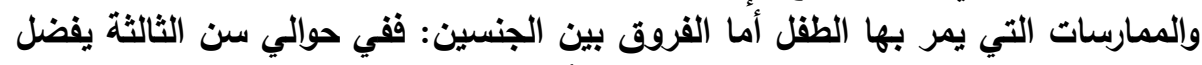

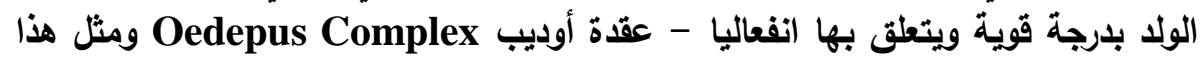

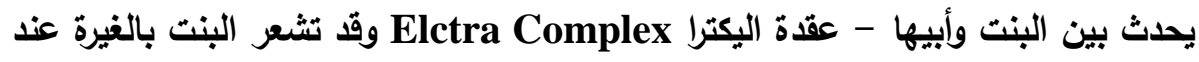
مشاهدة الاختلاف بينها وبين الولد في الأعضاء التناسلية - حسد القياء القضيب أو عقدة الخصاء ملثة الاخئ Castration Complex

وكل ما سبق يؤدى إلى توجيه الأسئلة بكثرة في جانب الأطفال، ودور الوالدين

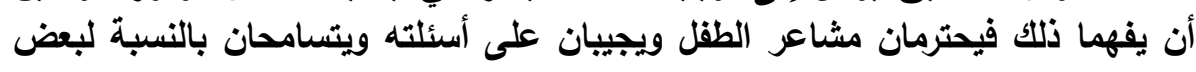

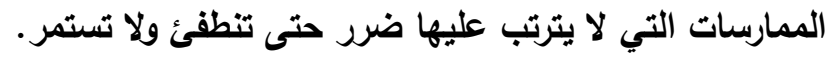

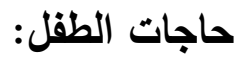

77 حامد زهان علم نفس النمو مرجع سابق ص 197.

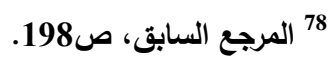

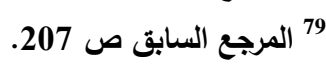

80 حامد زهان علم نفس النمو مرجع سابق ص 209. 
عند التعرض لحاجات الطقل هناك حقيقة مؤكلدة وهى تداخل حاجات الطقل وتأثرها ببعضها البعض، ولذلك يمكن تقسيم حاجات الطفولة كالتالي: أولا: تقسيم حاجات الطقولة إلى الحاجات المادية وغير المادية: وعلى ذلك يمكن تقسيم الحاجات الخاصة بالطفولة إلى:

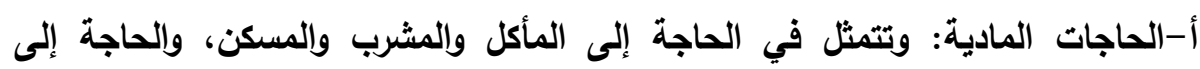

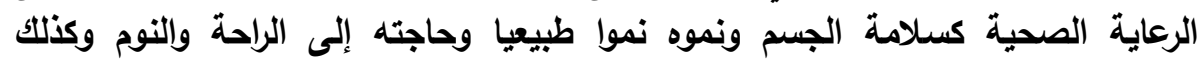
الحاجة إلى الرعاية التعليمية.

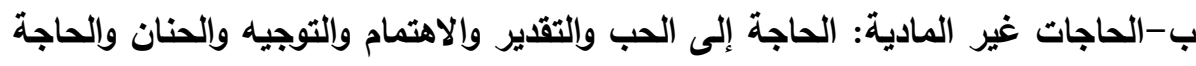

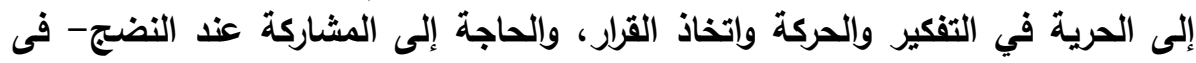

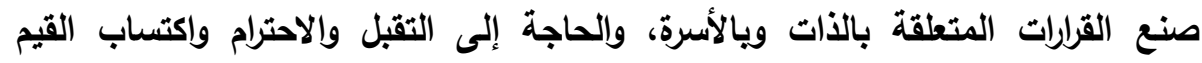
والمعايير السلوكية.

ثانيا: تقسيم حاجات الطفولة في ضوء مكوناته الشخصية: 1-الحاجات الخاصة بالنمو الجسمي للطقولة: أ-حاجة الطقل للغذاء والثراب ب-حاجة الطقل إلى الإخراج ج- حاجة الطقل إلى الراحة والنوم د - داجة الطقل إلى النشاط واللعب 2- الحاجات الخاصة بالنمو النفسي والاجتماعي:

$$
\begin{aligned}
& \text { أ- الحاجة إلى الأمن. } \\
& \text { ب- الحاجة إلى التقبل. } \\
& \text { ج- الحاجة إلى الرعاية الوالدية. } \\
& \text { د- الحاجة إلى التقدير الاجتماعي. } \\
& \text { هـ-الحاجة إلى توكيد الذات والتعبير عنها. } \\
& \text { و -الحاجة إلى الحركة والاستقلال. } \\
& \text { ز -الحاجة إلى النجاح. }
\end{aligned}
$$




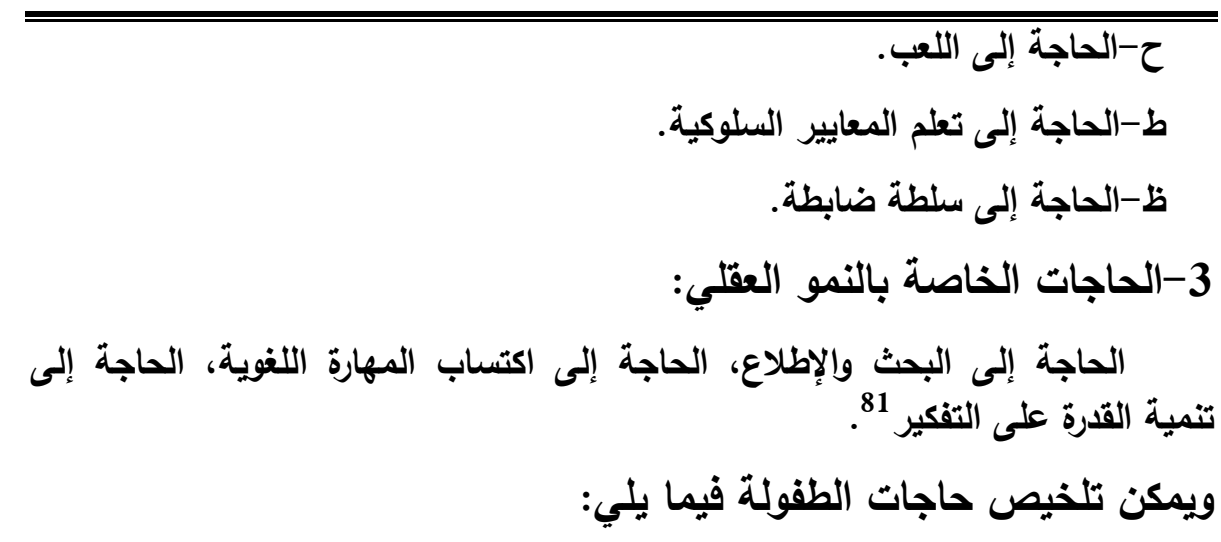

1-الحاجات التعليمية: فالطفل في حاجة لكي يتعلم ويحصل على العلم المناسب الذي

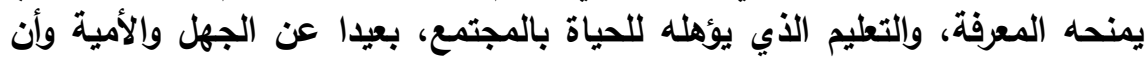

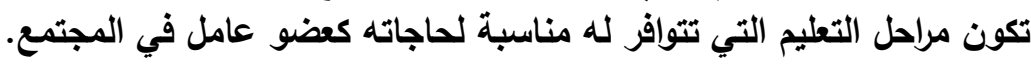

2-الحاجات الصحية والغذائية: وتتضمن الرعاية الصحية وتوفير الخدمات الطبية اللازمة

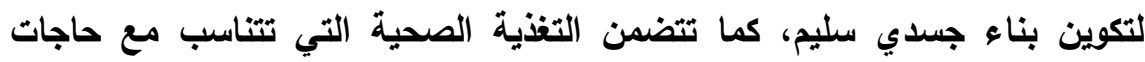
الجسم في مراحل النمو المختلفة ومتناسبة ومتصلة بمراحل التصنئ التعليم.

3-الحاجة للتنشئة الاجتماعية السليمة: بالرعاية الأبوية والأسرية وتوفير الحب والحنان

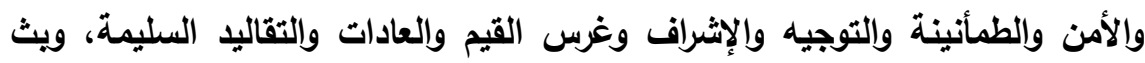
ثُقافة المجتمع وتعميقها للطفل.

4-الحاجات الاقتصادية: العمل على توفير ما يحتاج إليه الطقل من متطلبات مادية

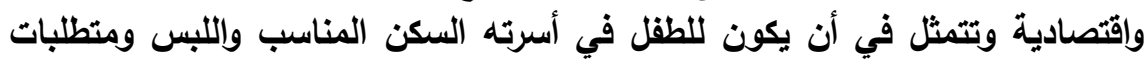

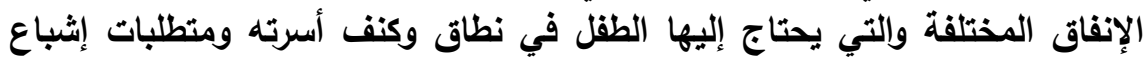
حاجاته الفردية.

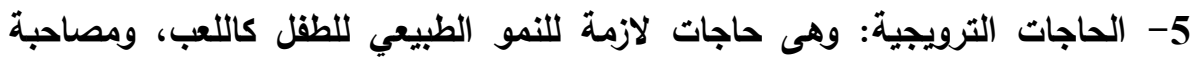
الأقران، والنزهة، وتوفير الوسائل التثقيفية للطقل ووسائل التئل الترفيه المناسبة.

6- الحاجة للتهيئة الاجتماعية والاندماج كعضو بالمجتمع: ويتضمن برامج التعليم

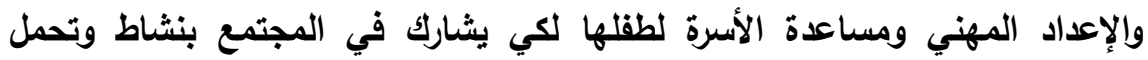
مسئوليات في نطاق الحصول على الخدمات الاجتماعية اللازمة لإثباع هذه لهاتهات الحاجة.

81 ثريا عبد الرؤوف جبريل وآخرون: الأسرة المعاصرة والممارسة العامة للذدمة الاجتماعية في مجال رعاية

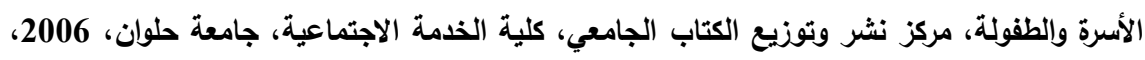

$$
\text { صد صد (357- (354) - (357). }
$$


7- الحاجة الثرعية والتشريعية: وتتضمن حاجات الطقل في الحصول على حقوقه

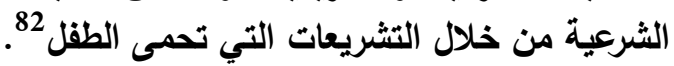

8- الحاجات والقضايا الثقافية: وهى أحد مكونات رعاية الطقل والتي يكون فيها الطقل

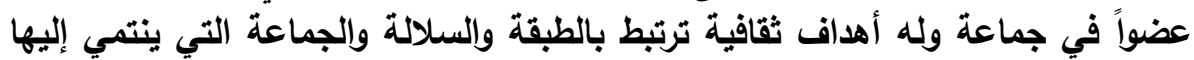
والتغيرات الايموجرافية التي ترتبط باحتياجاته وعليه يخطط لتقديم الخدمات الثقافية للأسر

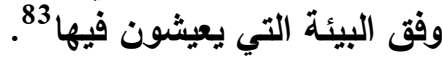
حقوق الطقل المفهوم والخصائص معنى الحق في اللغة: الحق لغة: "الحاء والقاف أصل واحد، وهو يدل على إحكام

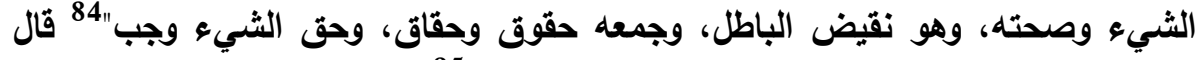

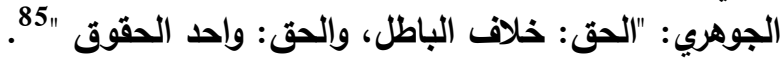

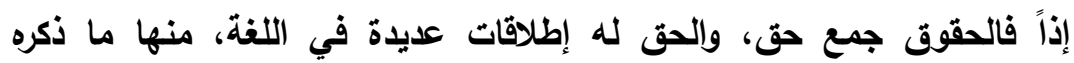

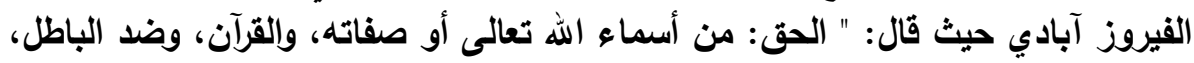

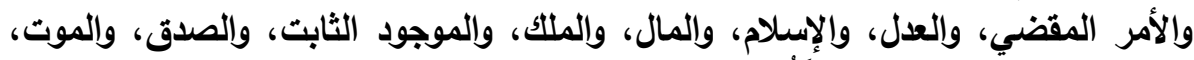

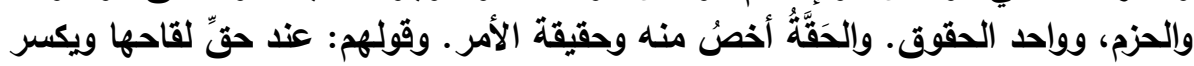

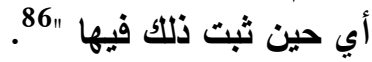

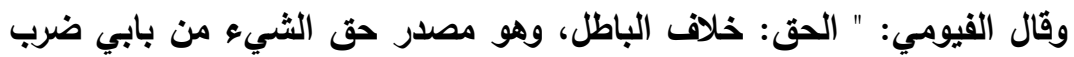

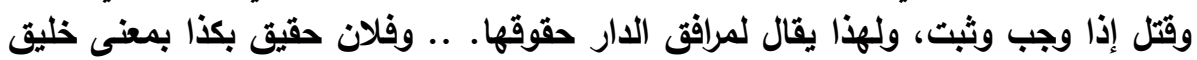

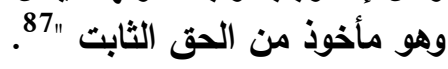
معنى الحق اصطلاحاً:

تطلق "الحقوق" اصطلاحاً على معان عدة، وياعتبارات مختلفة، وترجع تلك

الإطلاقات إلى معنيين أساسين:

82 إبراهيم بيومي مرعى، ملاك أحمد الرشيدي: الخذمة الاجتماعية ورعاية الأسرة والطفولة، الكتب الجامعي

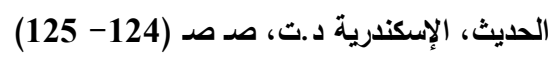

${ }^{83}$ Encyclopedia of social work, Washington Dc, 19th ،1995., p (430).

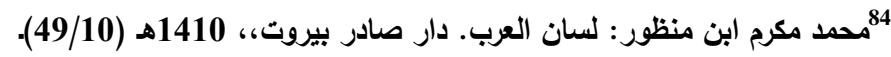

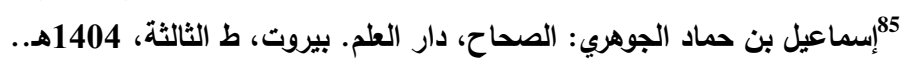

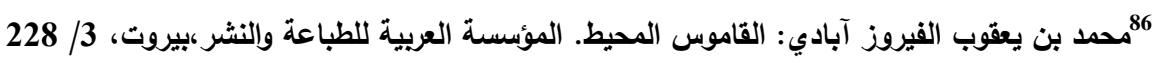

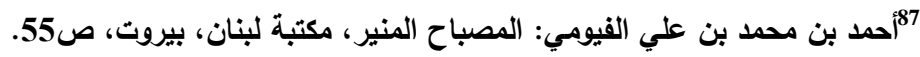


مجلة كلية التربية، جامعة الأزهر، العدد: (164 الجزء الثالث) يوليو لسنة 2015م

1

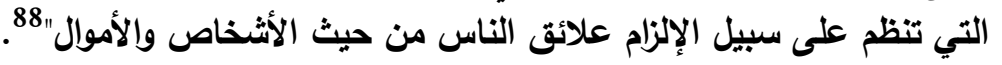

2) "المعنى الثاني باعتبار أثرها ومن تجب له، فتكون هي: المطلب الذي يجب لأحل

$$
\text { على غيره" }
$$

وقت عرف "الحق بمعناه العام بأنه: اختصاص يقرز به الثرع سلطة أو تكليفاًا.

قال الجرجاني: " الحق في اللغة هو الثابت الذي لا يسوغ إنكاره، وفي اصطلاح أهل

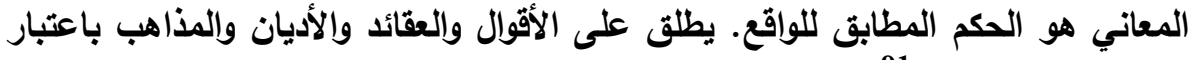
اشتمالها على ذلك " الصكم المطابت 91

ويعرف الطراونة حقوق الطقل بأنها: "عبارة عن مجموعة حقوق فردية وشخصية

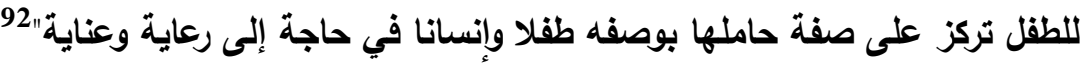

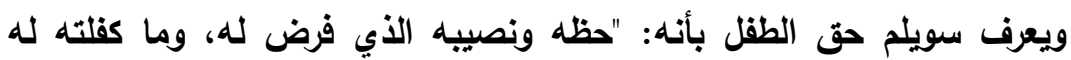

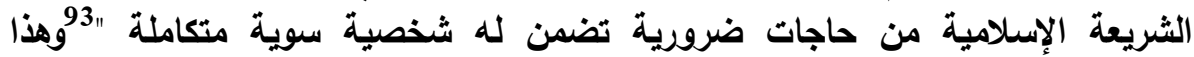
التعريف خاص بالطقل المسلم.

الخصائص العامة لحقوق الطقل 94 أولا: أن حقوق الطقل لا يقابلها واجبات عليه:

يمكن تسمية حقوق الطقل بالحقوق المطلقة، فهي حقوق يتميز بها الطقل،

فحقوق الرضاعة والحضانة والنفقة حقوق ينفرد بها الطقل لا يترتب عليها واجبات عليه. ثانيا: أن ممارسة الطقل لحقوقه تتميز بوضع خاص بالقياس إلى غيره من الكبار:

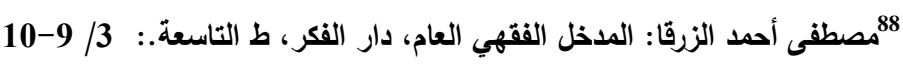

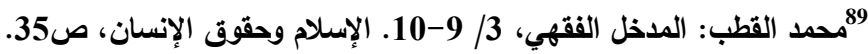

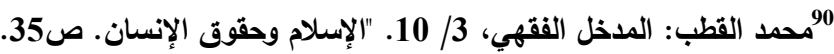

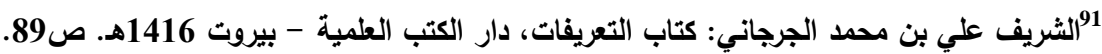
92مخلا الطراونة: حقوق الطقل دراسة مقارنة في ضوء أحكام القانون الدولي والثريعة الإسلامية

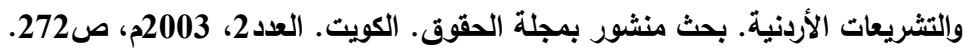

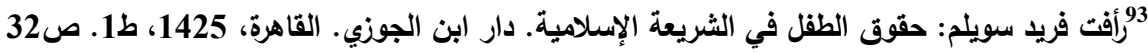
94 شثاء محمد القاضي: حقوق الطفل التعليمية والصحية وحق الحماية من سوء المعاملة والاستغلال، رسالة ماجستير، جامعة أم القرى. مكة، 1429.ص 58-59 باختصار وتصرف. 
إن ممارسة الحق تبدأ بطلبه والسعي إليه ثم استعماله، والاتتفاع بمضمونه، والمحافظة عليه، وليس هكذا حال الطقل، فهو لا يستطيع يطلب أو يسعى أله أو يحافظ على ولى حقه فيتولى ذلك عنه وليه.

ثالثا: أن حقوق الطقل مما لا يجوز التنازل عنها: خلال مرحلة الطفولة تظل حقوق الطقل تحت وصاية وليّه أو وصيه وفي حماية

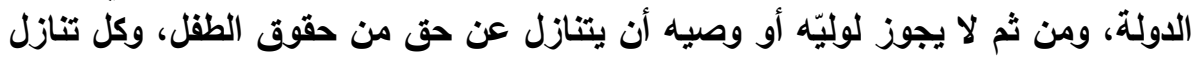

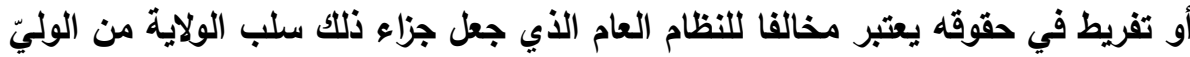

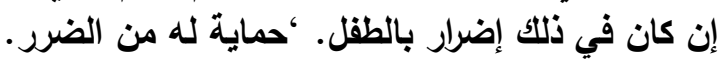
رابعا: أن حقوق الطقل تتسم بازدواج وتعدد المصالح التي تتعلق بها:

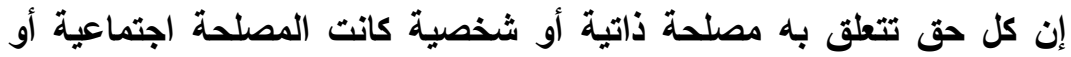

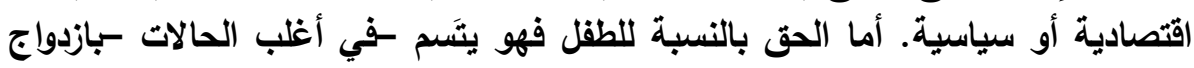

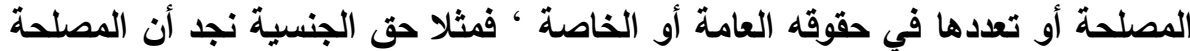

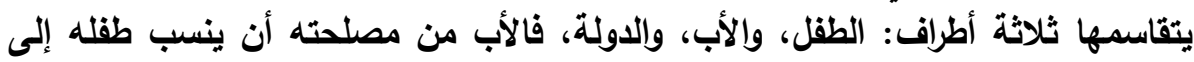

تبقى الإثارة إلى أن الذصائص الأربعة التي تتميز بها حقوق الطقل مرتبطة

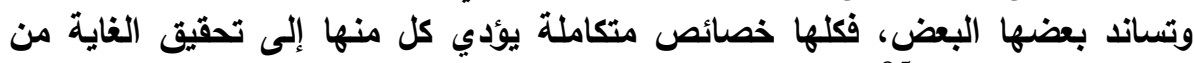
الآخر بصورة مترابطة 95 حقوق الطقل في الإسلام:

عنيت الثيعة الإسلامية بالأسرة حيث كانت خير مرثد لكل من الرجل والمرآة في

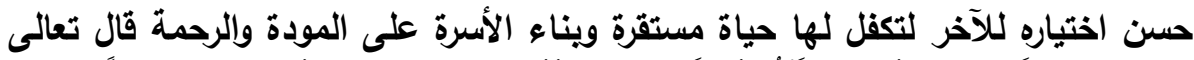

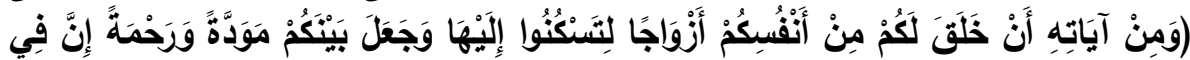

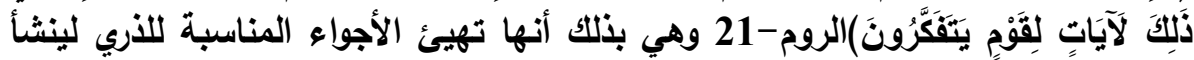

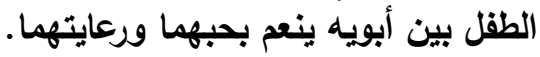

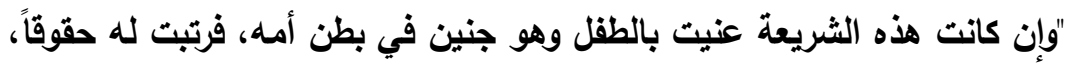

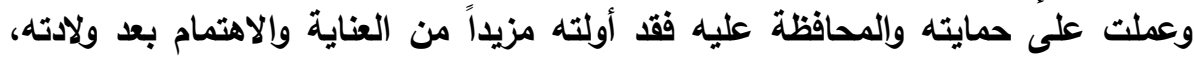

95 حنني نصار: تثريعات حماية الطفولة.، منثأة المعارف. الإسكندرية، (د.ت) ص30-30 باختصار وتصرف. 
مجلة كلية التربية، جامعة الأزهر، العدد: (164 الجزء الثالث) يوليو لسنة 2015م

وخروجه إلى الانيا فمنحته حقوقاً أخرى كثيرة تحقى بها مصالحه وتكفل له العيش

"ولم يكن هذا الاهتمام نابعاً من الاهتمام بالطفل فحسب، بل إنه يتمثل تكريم

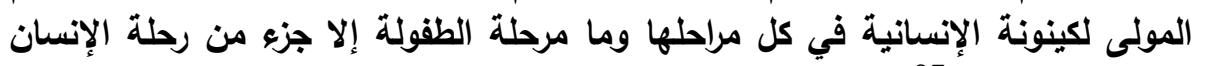

الثاقة في الحياة "الإنونة

"لقد جاء الإسلام ونظم أمور الإنسان في علاقته بريه ونفسه، وعلاقته بالآخرين الإنه

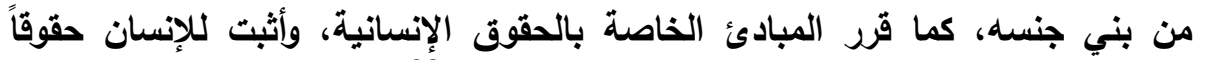

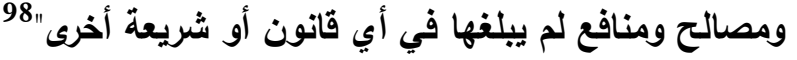

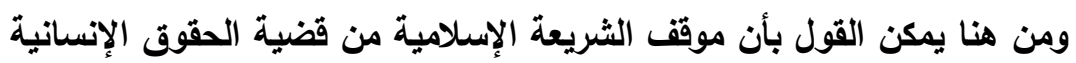

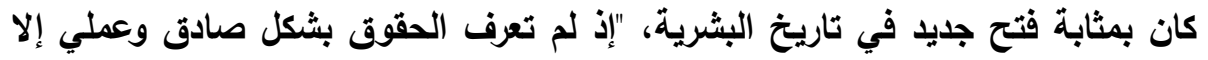

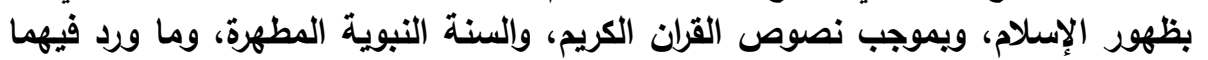

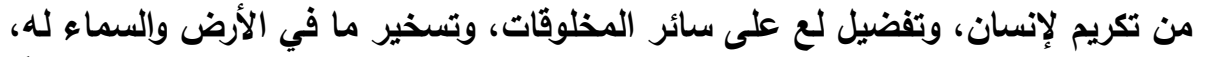

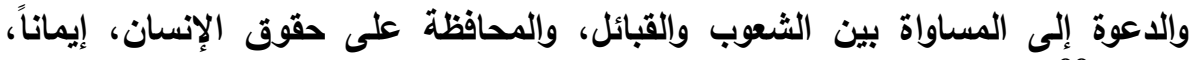
والتززاما" والدوة

وهذا ما يؤكده مدكور بقوله " فحقوق الإنسان المهددة اليوم والتي ندعو إلى

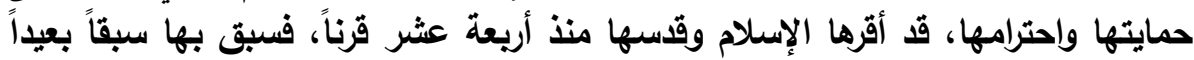

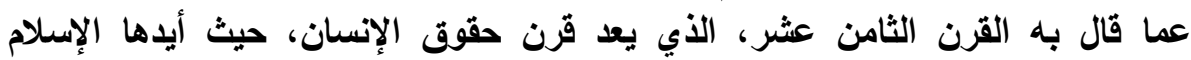

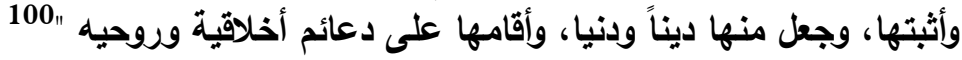

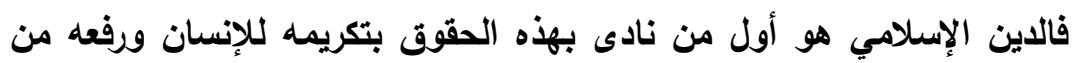

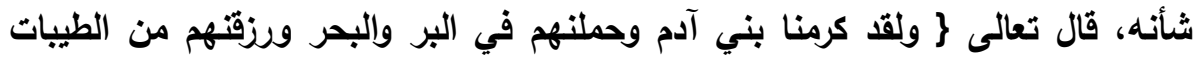

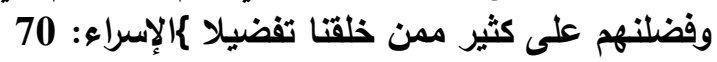

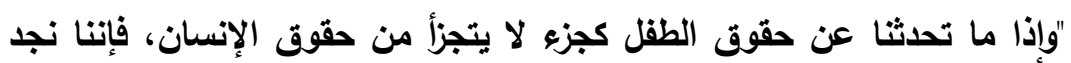

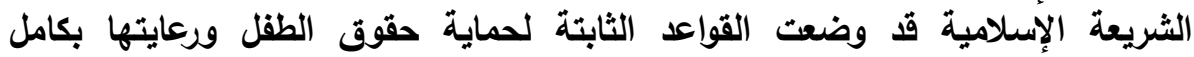

96 9مد الصالح: الطفل في الثريعة الإسلامية. مطبعة نهضة مصر . القاهرة. 1982م. ص63 97 زهير الأعرجي: الأخلاق القرآنية: دار الزهراء. بيروت. 1987م. (255/1) 80فاطمة فرج العتيبي: حقوق الطقل ورعايته في الإسلام وفي السويد. رسالة ماجستير. جامعة أم القرى.

1429. صמ.7.

999هبة الزحيلي: الفقه الإسلامي وأدلته. دار الفكر. دمشق. ط3. 1409. ص142، ص103 100إبراهيم مدكور: حقوق الإنسان في الإسلام أول تقتين لمبادئ الثريعة الإسلامية فيما يتعلق بحقوق الإنسان. منظمة المؤتمر الإسلامي. ط1، 1412. 
جوانبها، وفي مختلف سنوات الطفولة، إيماناً منها بخطورة هذه المرحلة، واعتبارها الطقل

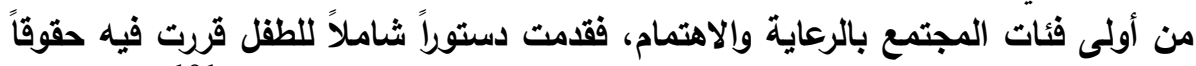

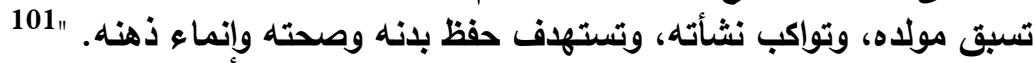

فرسول الله صلى الله عليه وسلم يبين لنا من خلال القصة التالية كيف حفظ

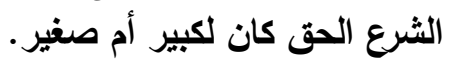

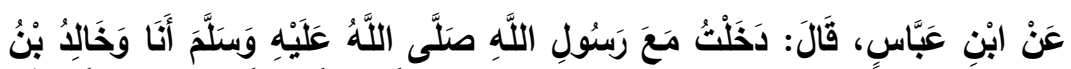

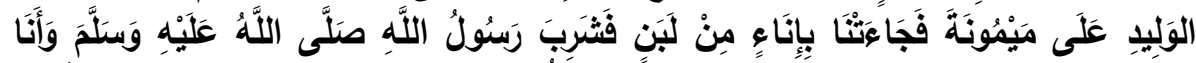

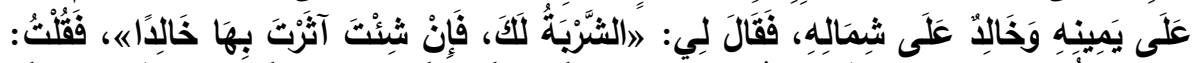

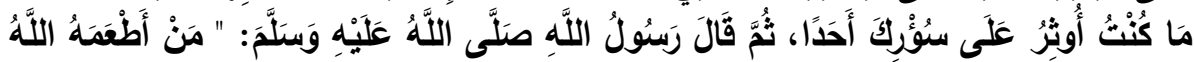

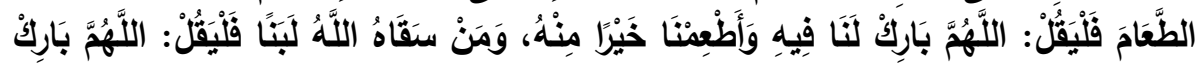

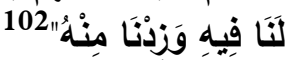

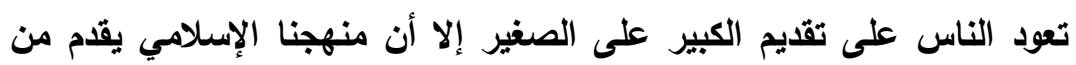

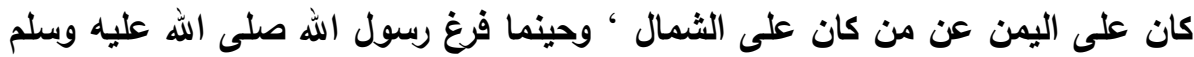

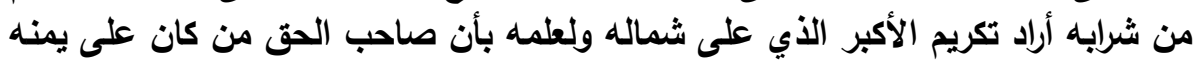

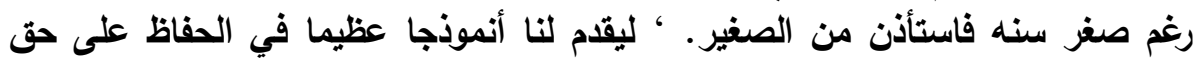

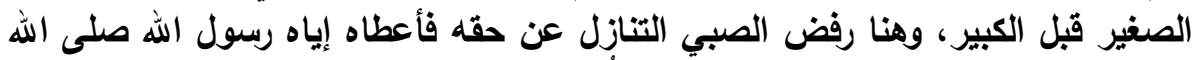

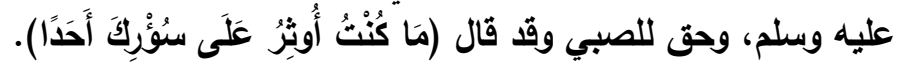
حق الطقل في الرعاية التعليمية في الثريعة الإسلامية:

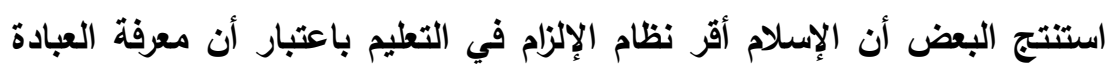

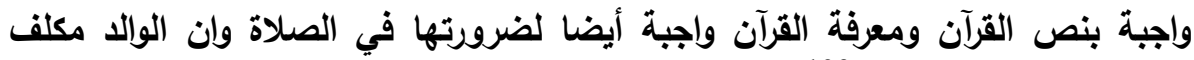
بتعليم ابنه القرآن والصلاة 103.

ويهذا قـ وضع الإسلام حق الطقل في التعليم في نطاق الفريضة ويتحدد هذا

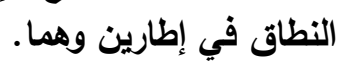

101 1429. ص7.

102 محمد بن عيسى الترمذي: سنن الترذذي، تحقيق إبراهيم عوض، استانبول، دار الدعوة، 1401هـ حديث رقم 3455

103 محمد على سكيكر: حقوق الطفل في الثرائع والتشريع، دار الجمهورية للصحافة، 2006، صد(143). 
مجلة كلية التربية، جامعة الأزهر، العلد: (164 الجزء الثاثث) يوليو لسنة 2015م

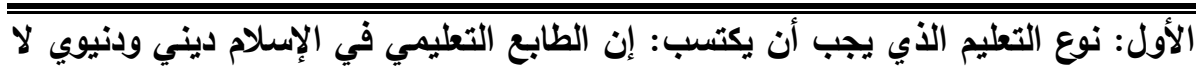

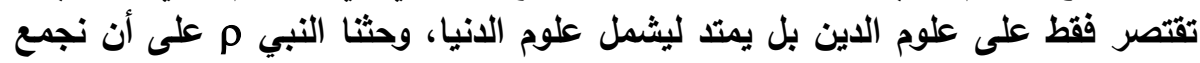

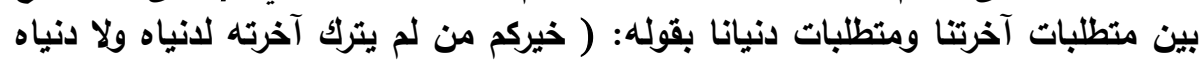
لآخرته ولْم يكن كَلا على الناس ). ثانيا: المكلف بفريضة التعليم: لم يفرق الإسلام بين الرجل والمرأة في العلم والتعليم فالأمر

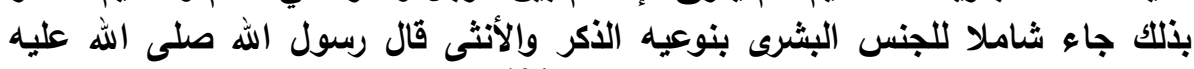

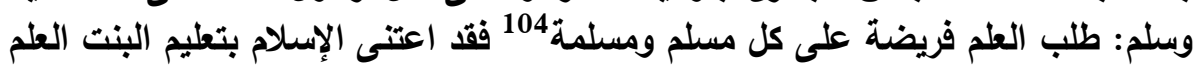
النافع والثقافة المفيدة وقد ثبت تاريخيا أن المرأة في ظل الإسلام وصلت فلت أسمى درجات الإسلات العلم والثقافة 105.

حق الطقل في الرعاية الصحية في الشريعة الإسلامية جاءت الثريعة الإسلامية مؤكدة على ذلك فنصت على الآتي: * إتباع القواعد الصحية في المأكل والمشرب والنوم. * معالجة المرض بالتداوى. * التحرز من الأمراض السارية. * تطبيق مبأ لا ضرر ولا ضرار.

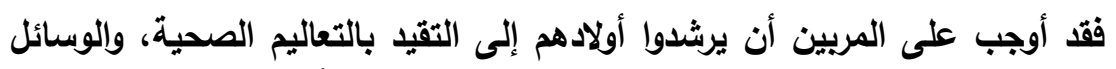

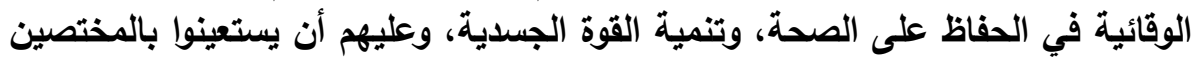

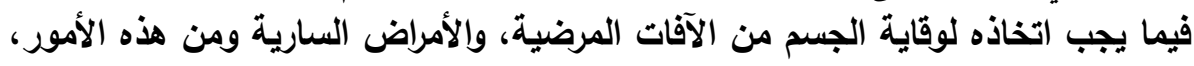

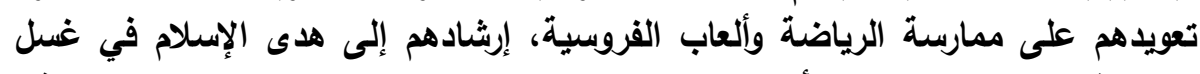

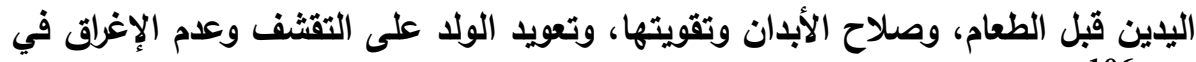
النعم 106.

حق الطقل في الرعاية الثقافية في الثريعة الإسلامية:

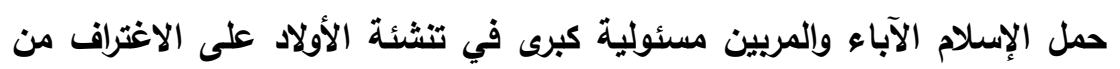

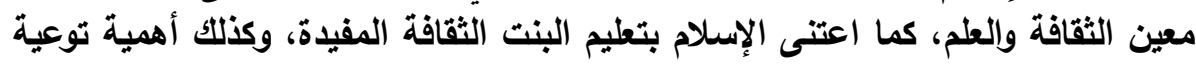

104 هلالى عبد اللاه أحمد، خالد محمد القاضي: حقوق الطقل في الثريعة الإسلامية والمواثيق الدولية

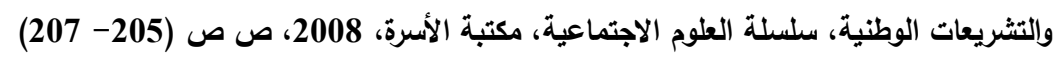

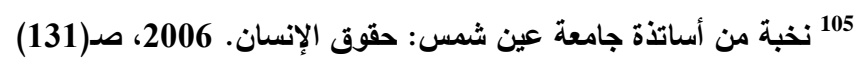
106 المرجع السابق، صد(130- 131) 
الطقل فكريا منذ حداثة سنة، ونعومة أظاهره، إلى أن بصل سن الرشد ويؤكد على ارتباط

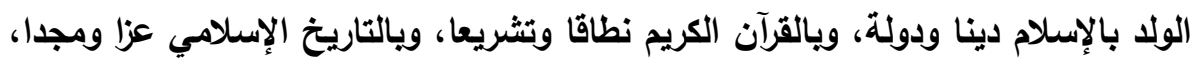

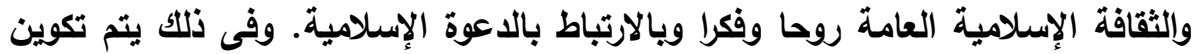

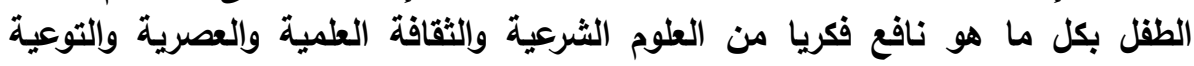
الفكرية والحضارية حتى ينضج فكر فكريا ويتكون علميا وثقافيا.

وفي هذا السياق يمكن الوقوف على بعض ملامتح رعاية الطقل في الإسلام، والتي يمكن إجمالها فيما يلي الئي 107 :

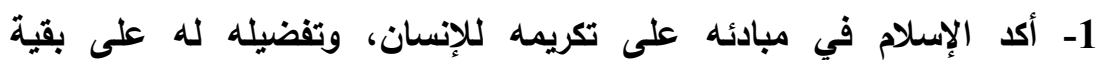

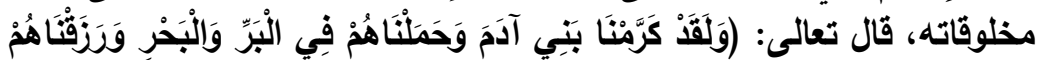

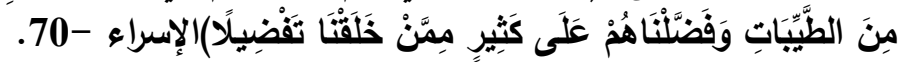

2- أبقى الإسلام على المظاهر الإيجابية لرعاية الطقل التي كاتت سائدة قبل بعثة

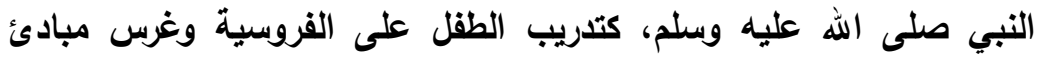
الشجاعة والكرم في نفسه

3- ألغى الإسلام المظاهر السلبية في معاملة الطقل التي كاتت سائدة قبل ظهور

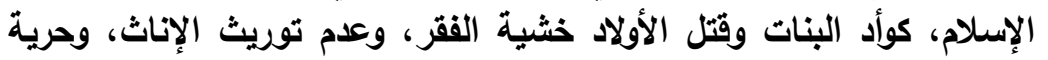

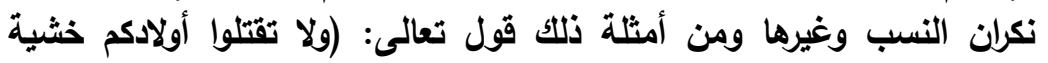
إملاق نحن نرزقهم وإياكم إن قتلهم كان خطئاً كبيراً)

4- تضمن الإسلام نسقاً متكاملاً من الأسس والمبادئ السامية التي تنظم حياة الإنسان، وحدد فيها أسس رعاية الطقل، وحقوقه الأسله

5- سبق الإسلام بمبادئه في مجال حقوق الإنسان ورعاية الطقولة التشريعات

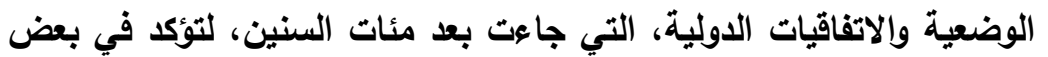

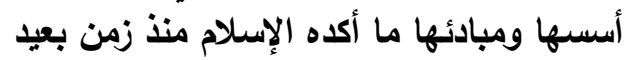

6- حلدت أسس رعاية الطفولة ومبادئها التي نادى بها الإسلام الأطر القانونية،

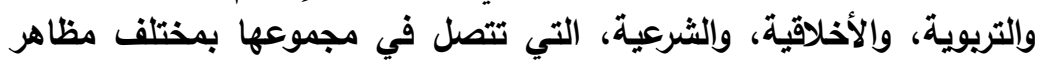
حقوق الطقل ورعايته

وقد نص العلماء بالتفصيل على حقوق الأطفال ولُعل من أبرزها: 1- - مق الطقل في المأكل والمشرب.

107 إبراهيم مدكور: حقوق الإنسان في الإسلام أول تقتين لمبادئ الثريعة الإسلامية فيما يتعلق بحقوق الإنسان، بتصرف واختصار. 
مجلة كلية التربية، جامعة الأزهر، العدد: (164 الجزء الثالث) يوليو لسنة 2015م

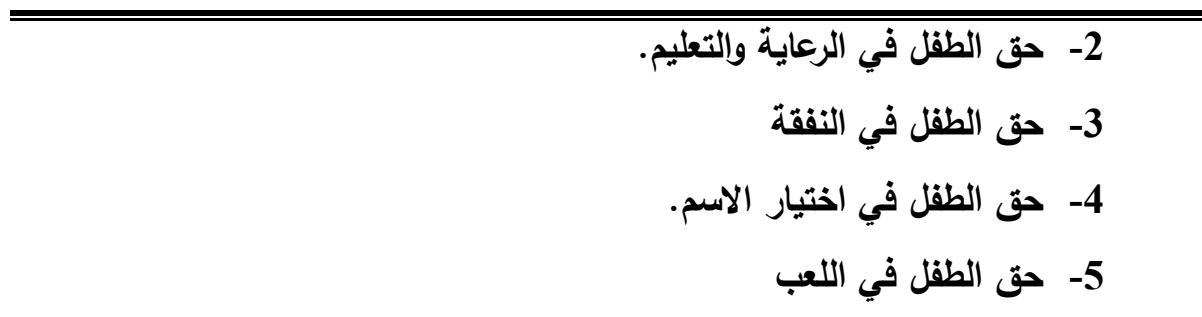

وهذا الحق أي حقه في اللعب لكون اللعب نشاط ينمي كافة قدرات الطقل، وهذا

ما سيوضحه الباحث.

$$
\text { مفهوم اللعب: }
$$

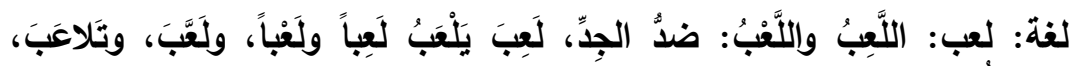

$$
\text { وَتَكَبَبَ مَرَّة بَعْدَ أُخرى لُعبد } 108
$$

لعِب، ما يُلْعَب به من مداعبة وخداعِ مُضْحِكِ "ألاعيب الطُّلَّب/ الظرفاء".

اللعب اصطلاحا: يعرفه فرويل: "النشاط الروحي النقي للإنسان فهو يشتمل على فئل

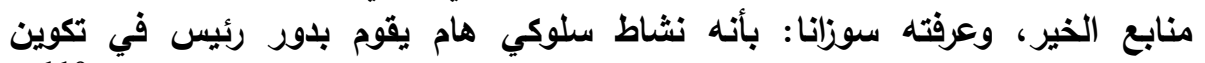

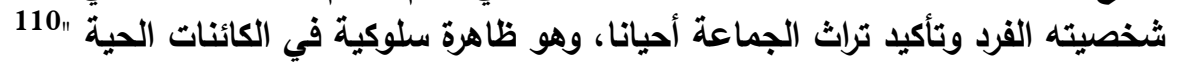

تعريف الموسوعة البريطانية: "تشاط طوعي من أجل السرور" 111

$$
\text { مميزات اللعب وخصائصه } 112
$$

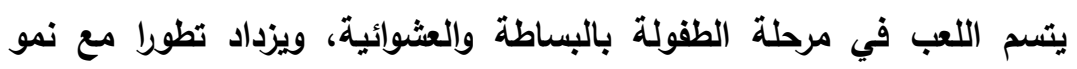

الطفل إلا أن لعب الأطفال يتصف بعدة خصائص تميزه عن لعب الكبار.

1- اللعب يعكس واقع الطفل: فالأطفال يلعبون ببراءة كاملة لذا يسهل تثخيص واقعهم من خلال لعبهم (فالأطفال لا يتقيدون بشروط الاطفون براعة الموقف الحقيقي ولا بالزمن أو

108محد مكرم ابن منظور: لسان العرب. دار صادر بيروت،، 1410هـ، ج1. ص2739

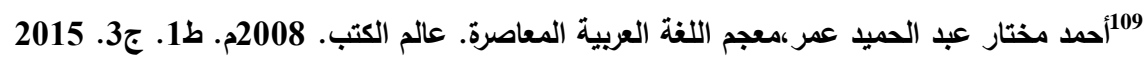
110نوف محيي الدين: اللعب في حياة الأطفال: الطقل العربي والمستقبل. الكتاب العربي. سلسلة فصلية

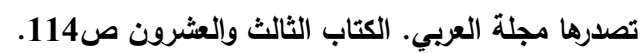

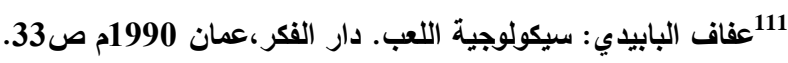

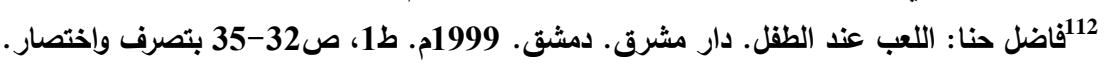


بالتسلسل المنطق للأحداث ونعاقبها. إنهم يعتقدون وهم يلعبون في الغرفة مثلا أهم

$$
\text { يسبحون في الغرفة }
$$

2- اللعب يعبر عن ذات الطقل وغاية في ذاته: المتتبع للطقل وهو يلعب يستطيع التعرف لأله

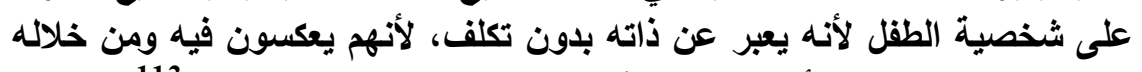

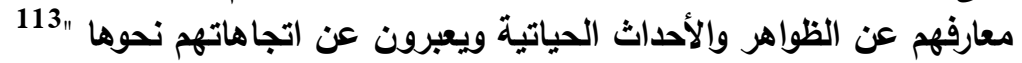

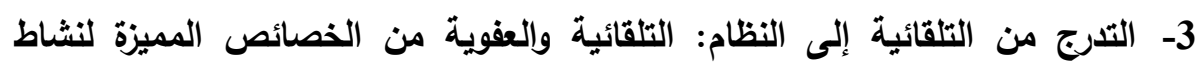

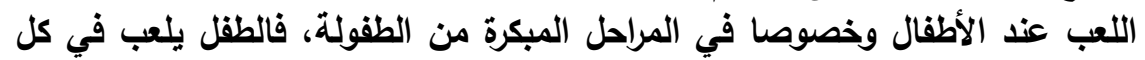

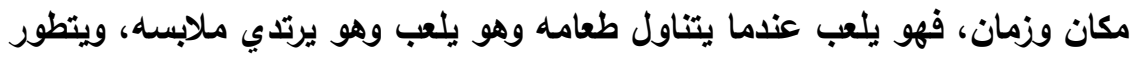
اللعب مع الطقل حتى يأخذ شكله النظامي الواضح.

4- تناقص أنثطة اللعب الكمية وتزايدها من الناحية الكيفية: مع تقدم النمو تقل أنشطة

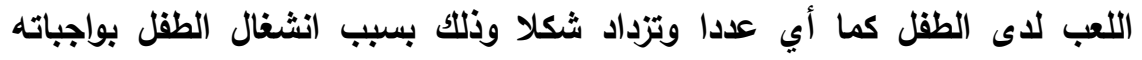

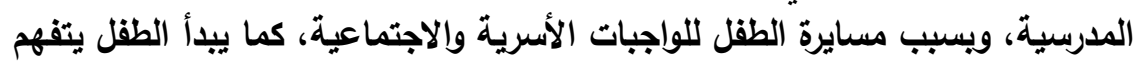
الحياة وتتحدد على إثر ذلك هوياته وتتركز على أنثطة معينة.

5- تناقص النشاط البذني وازدياد النشاط العقلي: وهذا يتناسب طردا من النمو العقلي

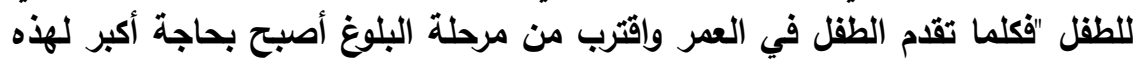

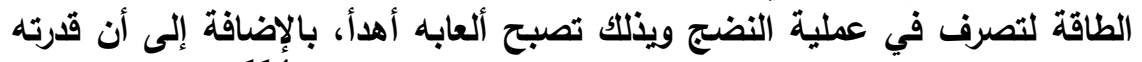
التفكيرية تكون قد نمت بشكل جيد ويصبح أقدر على استعمالها" 114

$$
\text { وظائف اللعب:115 }
$$

للطقل وظائف هامة ومفيدة فمن خلاله يطور الطقل عقله وجسده، ويحقق الإنه

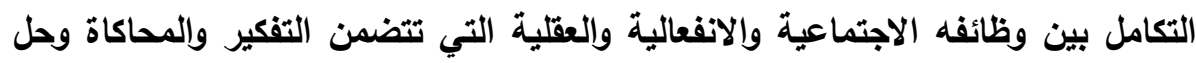
المشكلات والحديث والتخيل

$$
\text { وللعب عدد من الفوائد الأخرى: }
$$

1- من الناحية الجسدية: فهو ضروري لنمو العضلات وتتاسقها وكلما ازداد استخدام

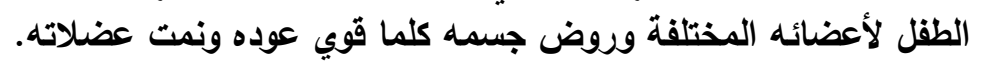

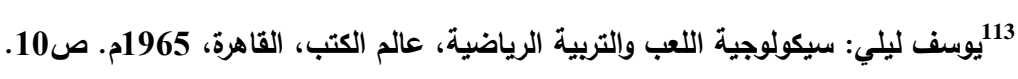

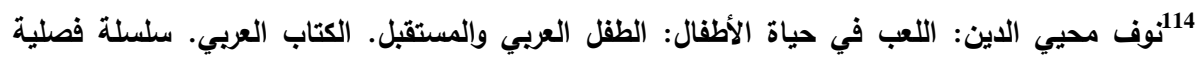

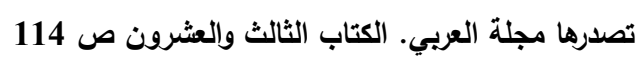

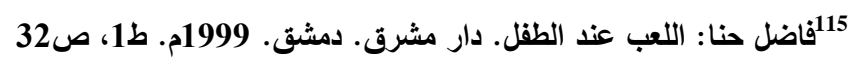


2- من الناحية التربوية: الطفل الذي يلعب يتعلم مهارات جديدة ويفرح عند انجازها ويصل

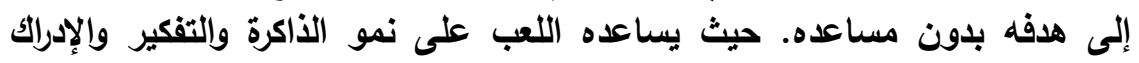

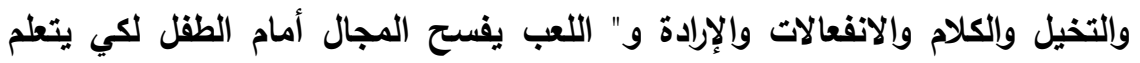

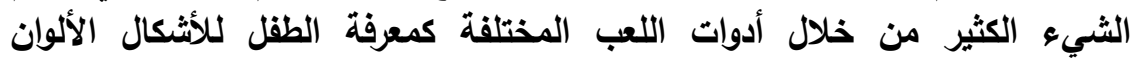

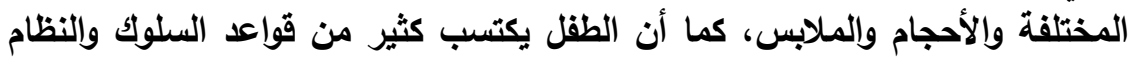

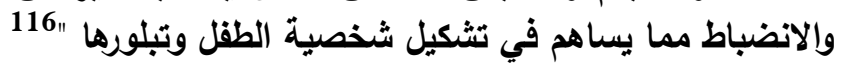

3- من الناحية الاجتماعية: الطقل كائن اجتماعي تتطور خصائصه الاجتماعية مع نموه

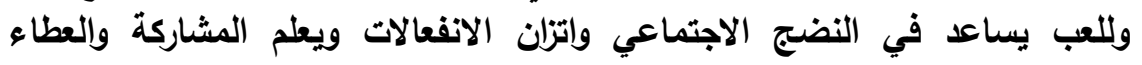

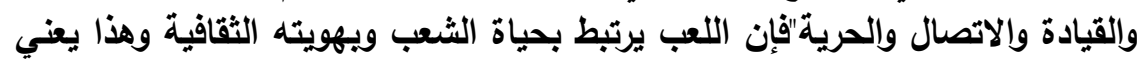

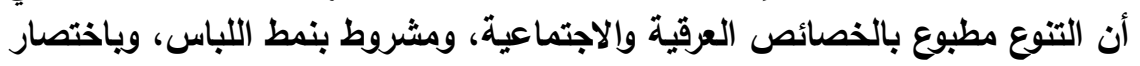
فإن لعب الأطفال بتقاليده ويقواعده يشكل مرآة اجتماعية حقيقة

4- من الناحية النفسية والعلاجية" لا تقتصر أهمية اللعب على تنمية المهارات الحركية

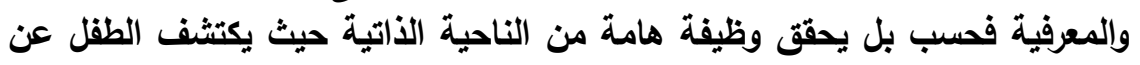

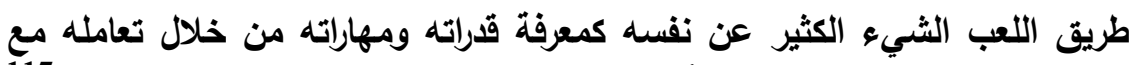

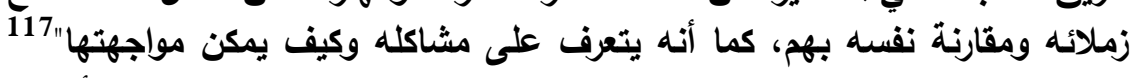

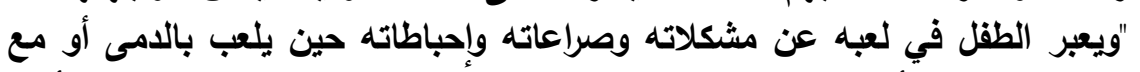

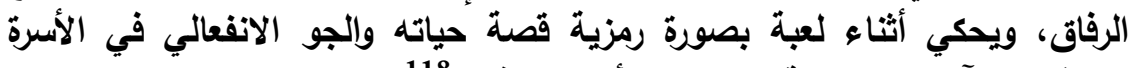

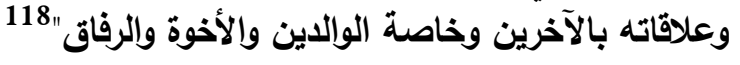

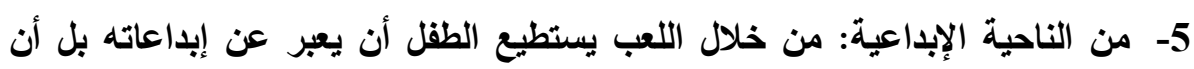

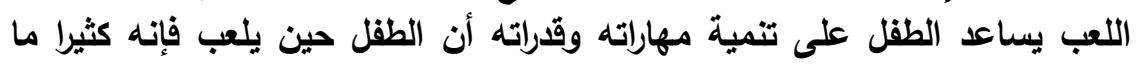

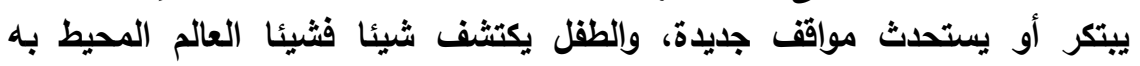
والعلاقات التي تربط الأثشياء مع بعضها التهات البعض.

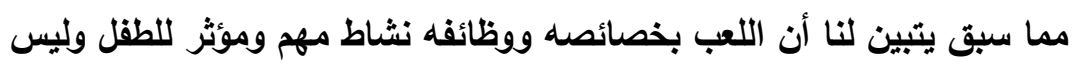

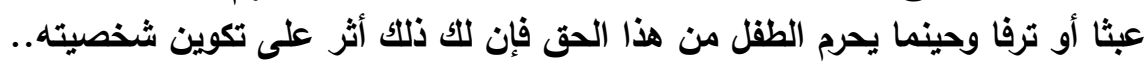
والتربية الإسلامية وهي التربية المثالية تبين لنا كيف تحافظ على هذا الحق

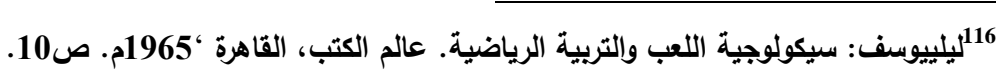

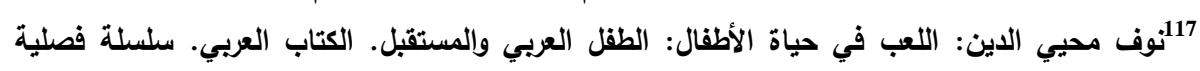

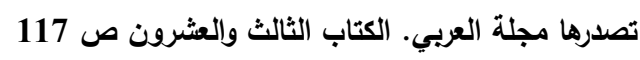

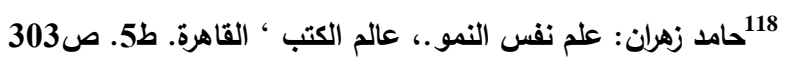




\section{حق الطقل في اللعب من منظور التربية الإسلامية:}

اللعب شيء رئيسي في تكوين حياة سوية للطقل، وهو للطفل كالعمل بالنسبة

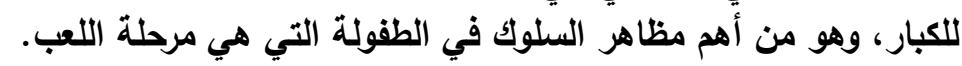

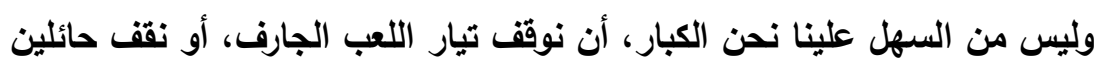

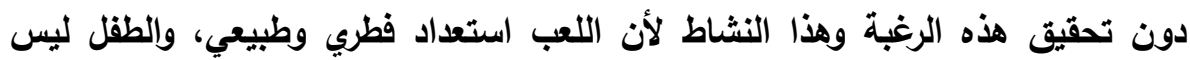
بحاجة إلى أن يتعلم اللعب ولكن في حاجة إلى التوجيه والإرشاد والتنظيم 119

إن اللعب هو أنفاس الحياة، بل هو حياة الطفل نفسه، ومن ثم فلا غرو أن يعتبر

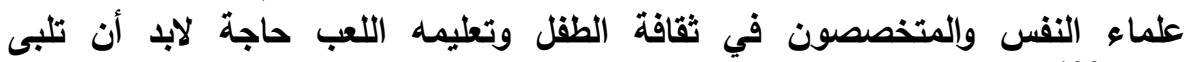

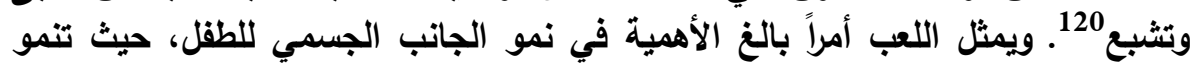

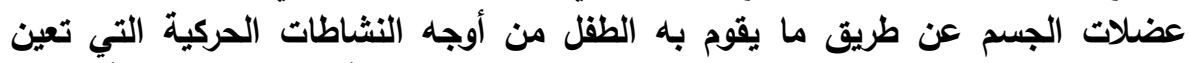

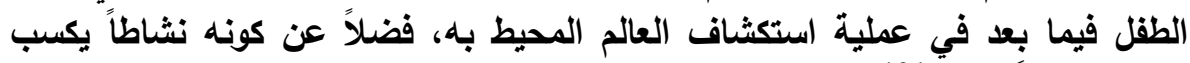

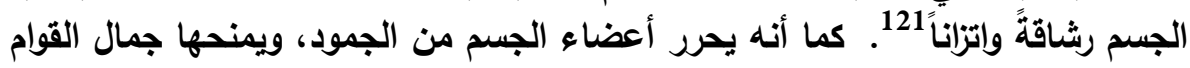

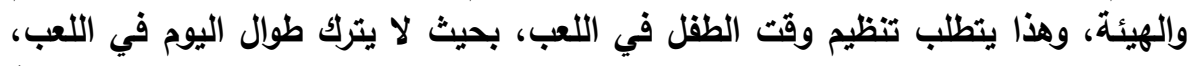

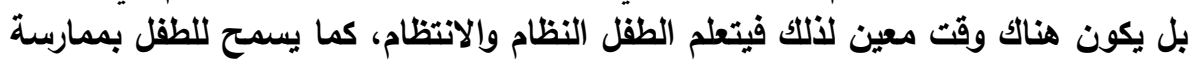

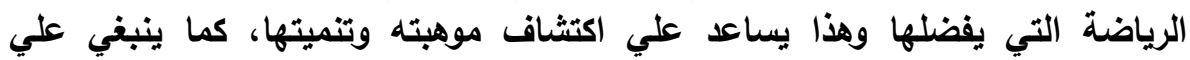

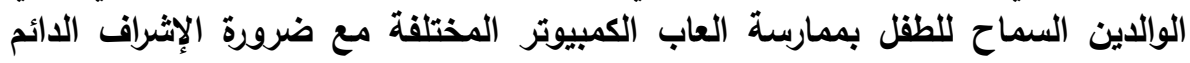
علي ذلك.

مما سبق تبين لنا الأثر الكبير للعب على الطقل فهو" بالنسبة للطفل حاجة فطرية

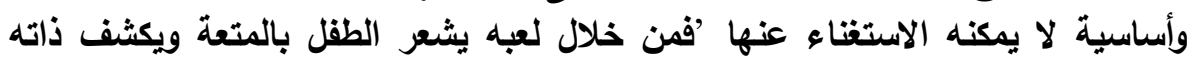

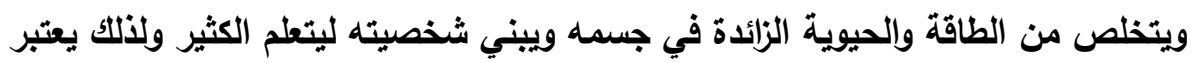

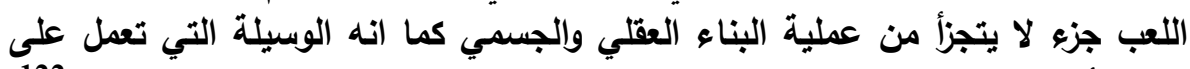

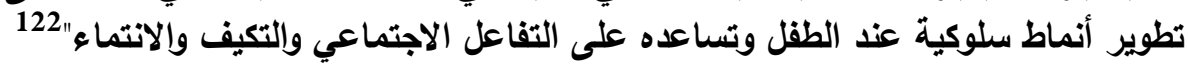

119 كريمان عبد المنعم سرور: التريبة الرياضبة والفتاة المسلمة، بحث مقدم إلى المؤتمر العالمي الخامس

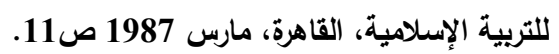

120 محمد بسام ملص: أثثر نثاط الطفل التثثيلي في التربية، رسالة الظليج العربي، مكتب التربية العربي

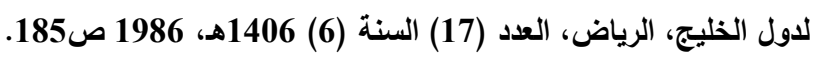

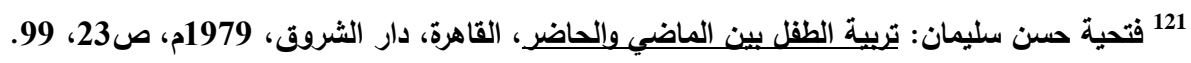
122 محمد سعيد مرسي: فن تربية الأولاد في الإسلام. دار النشر والتوزيع الإسلامية. 1988، 1998م. القاهرة. 
وحتى ينشأ الطفل قويا صحيح الجسم والعقل قادرا على القيام بالتكاليف الواجبة

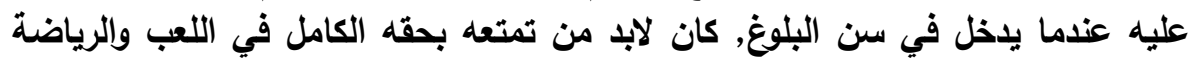

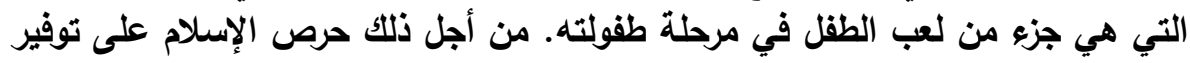

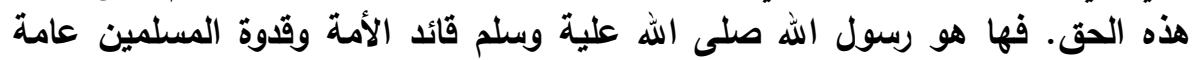

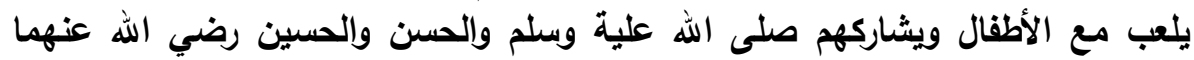

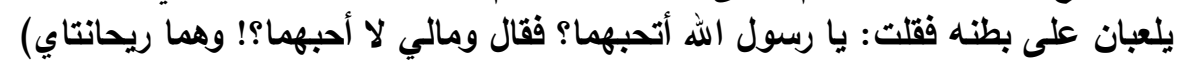

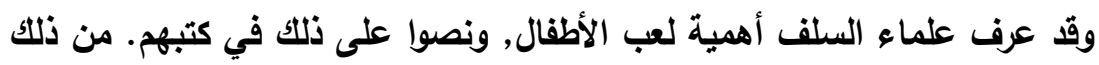

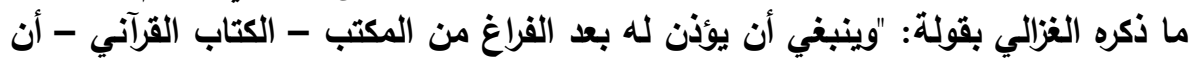

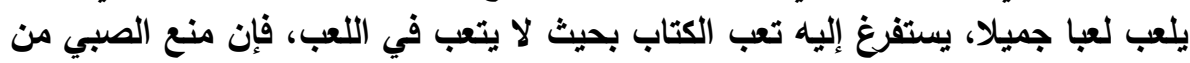

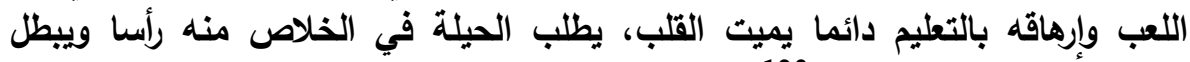

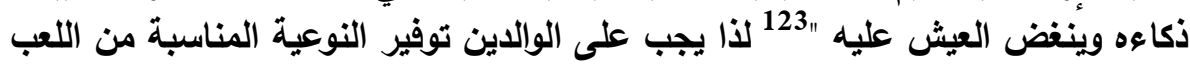

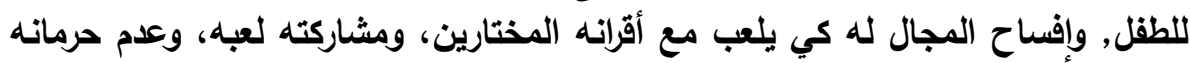

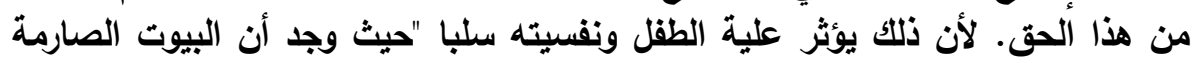

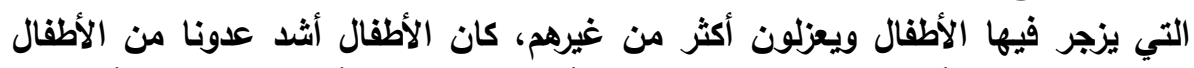

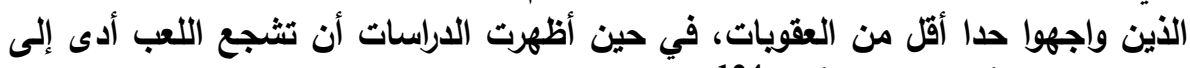

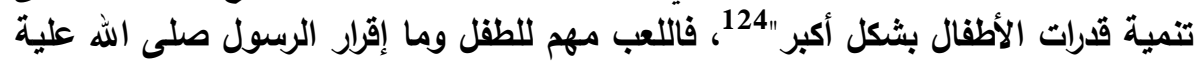

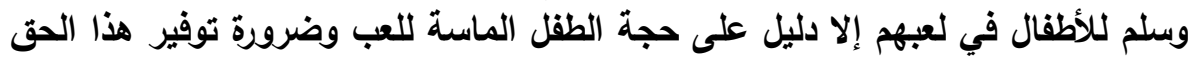

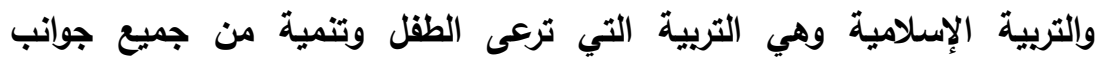

شخصيته تحفظ للطقل حقه في اللعب لما لذلك من أهمية في تكوين شخصيته الثيله

وفي ما يلي صور تبين عناية التربية الإسلامية بهذا الحق واستثماره الاستثمار

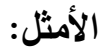

صور من رعاية حق الطقل في اللعب من منظور التربية الإسلامية:

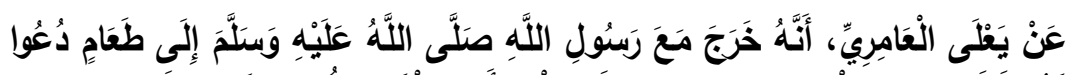
(1

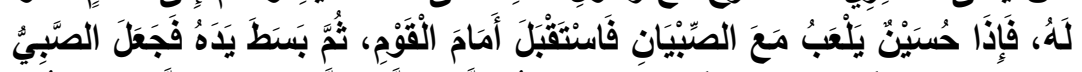

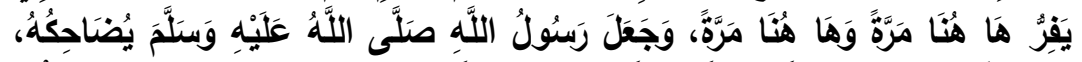

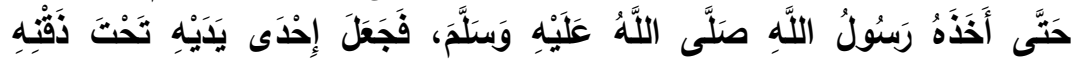

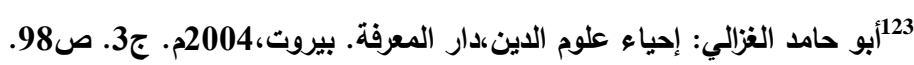

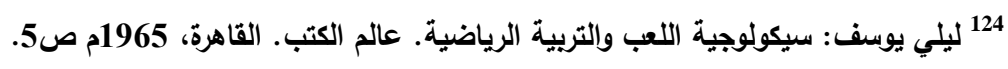




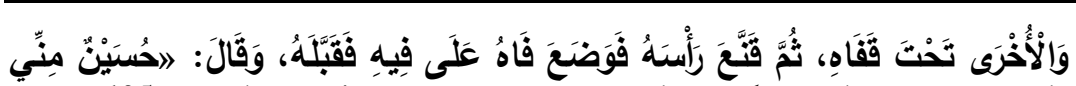

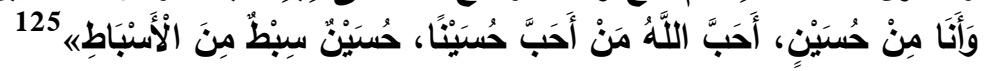

هذه الصورة الرائعة التي جمعت كثير من الخصال (الرحمة، والمحبة، والرفق،

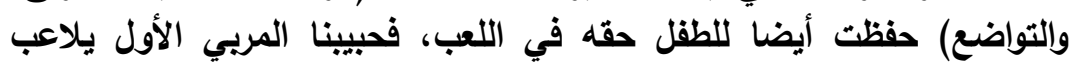

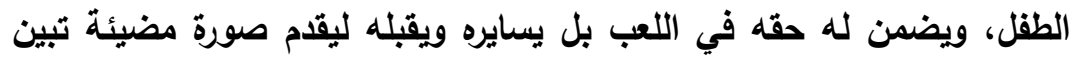
حفظ التربية الإسلامية للطفل حقه في اللعب.

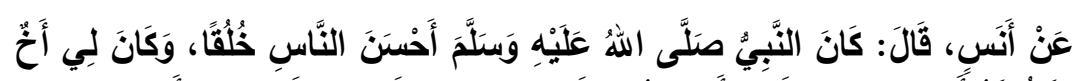

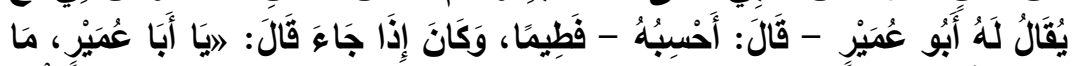

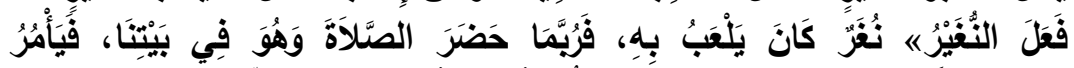

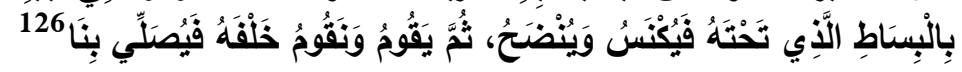
يقام المصطفى صلى الله عليه وسلم نموذجا لرعاية الطفل وحفظ حقه حتى في

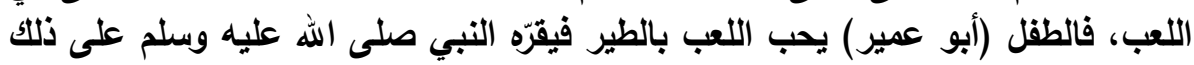

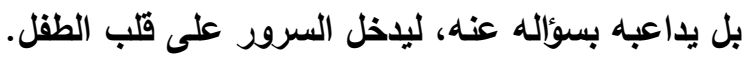

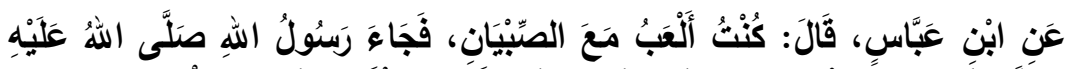

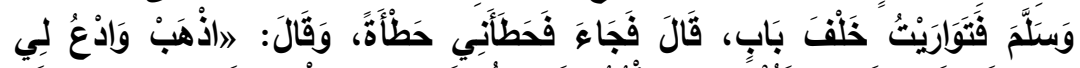

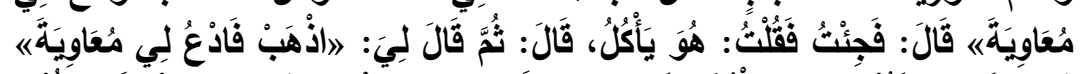

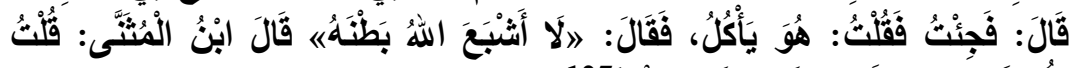

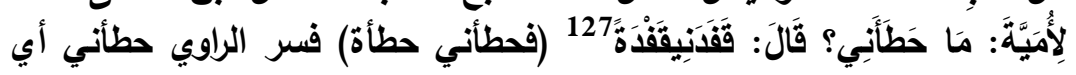

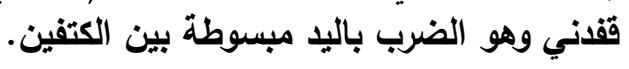

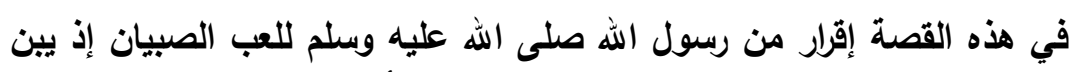

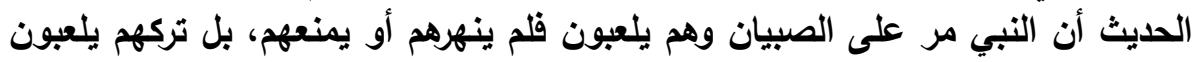

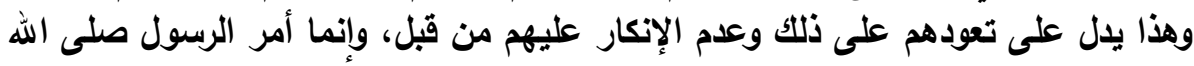

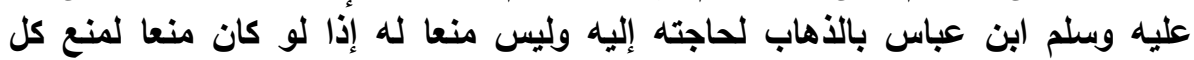

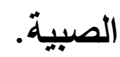

فاللعب حاجة فطرية لاى الأطفال، وهذا الحديث يدل على مرعاه هذا الجانب، فالنبي

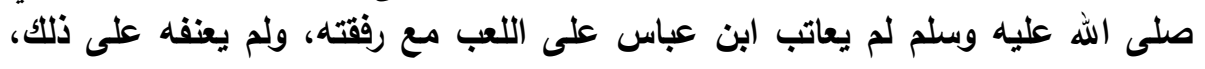
125 محمد بن يزيد ابن ماجة: سنن ابن ماجة، تحقيق محمد فؤاد عبد الباقي، بيروت. دار إحياء التراث

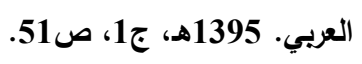

126 محمد بن إسماعيل البخاري: صحيح البخاري. بيروت. دار ابن كثير. 1307هـ، رقم6203 
مجلة كلية التربية، جامعة الأزهر، العلد: (164 الجزء الثاثث) يوليو لسنة 2015م

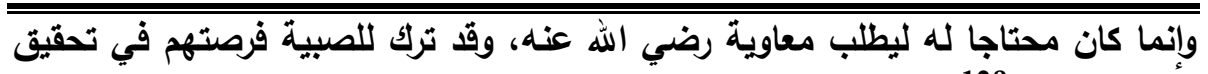

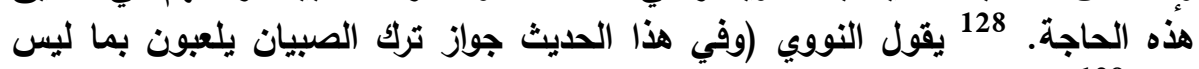
حرام) 129

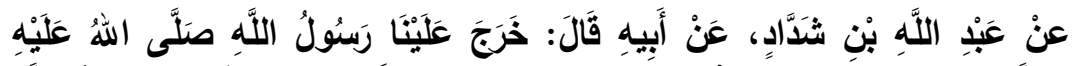
$(4$

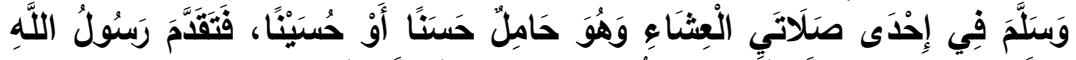

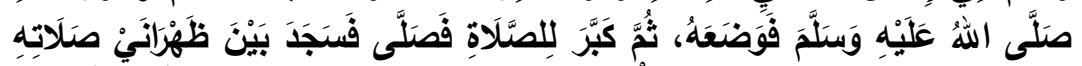

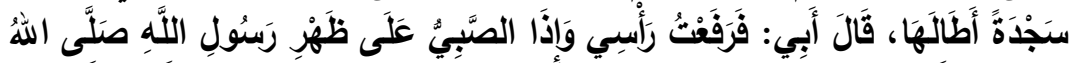

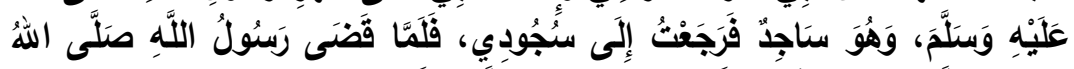

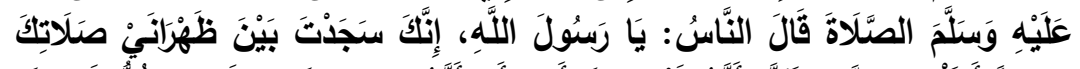

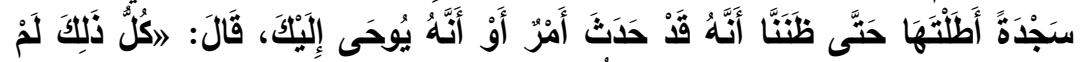

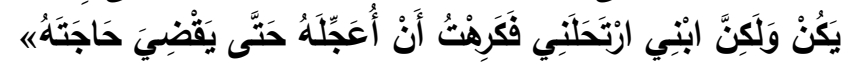

في هذه القصة تأكيد على أهمية حصول الطفل على حقه في اللعب وأن اللعب التبل

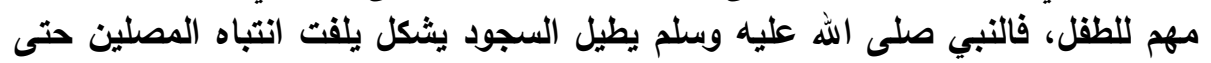

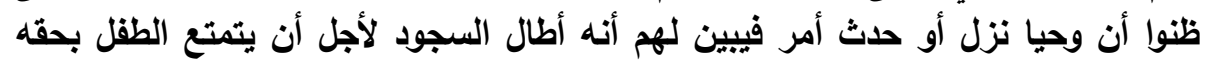

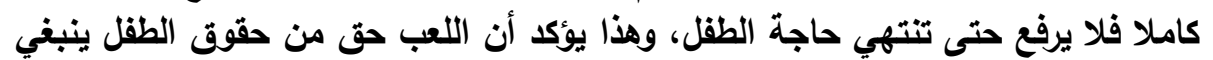
إعطاؤه كاملا مهما كانت الأسباب.

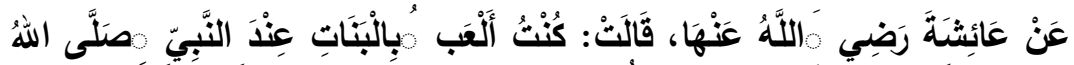
(5

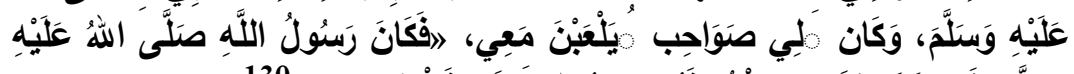

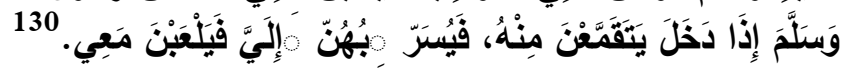
(صواحب) جمع صاحبة وكن جواري صغيرات من أقرانها في السن

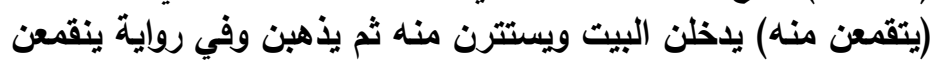

$$
\text { (فيسربهن إلي) يرسلهن وإحدة بعد الأخرى]. }
$$

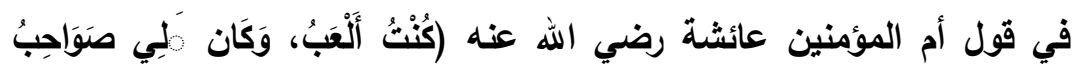

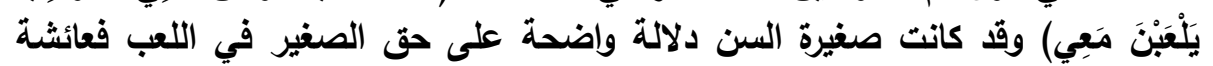
رضي الله عنا تحكي ذلك وفي بيت النبوة وقد تزوجت من رسول الله صلى الهى الله عليه وسلم

128محمد صالح العلوي: خطاب النبي صلى الله عليه وسلم للطفل المسلم وتطبيقاته التريوية. رسالة

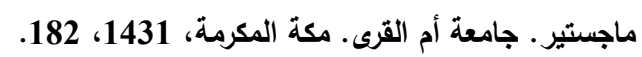
129 محي الدين يحي بن شرف النوائ النور: المنهاج في شرح صحيح مسلم، بيت الأفكار الدولية للتوزيع والنشر .

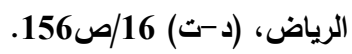
130 محمد بن إسماعيل البخاري: صحيح البخاري. بيروت. دار ابن كثير. 1407هـ. ج8، ص31 
ولم يمنعها ذلك ممن ممارسة حقها في اللعب بل أ ن رسول الله صلى الله عليه وسلم

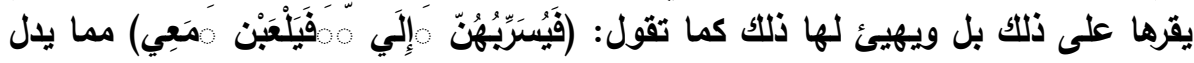
على إيمانه صلى الله عليه وسلم بحق الصغير في اللعب والترويح.

مما سبق يتبن لنا عناية التربية الإسلامية وحفظها لحق الطفل في اللعب كنشاط

$$
\text { ضروري يساهم في تثكيل شخصيته. }
$$

"إن الترويح التريوي يقوم بدور تريوي مؤثر في تنمية شخصيات الأبناء عن فئه

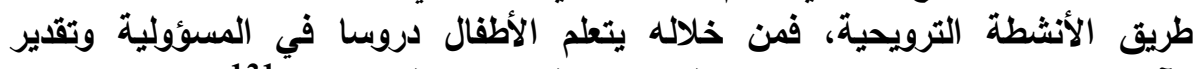

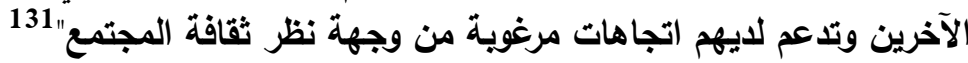

ويستتتج الباحث مما سبق حفظ التربية الإسلامية لحق الطقل من عدة أوجه:

1 ) تواتر النصوص الشرعية التي تثبت للطقل حقه في اللعب.

2) إثارة علماء الأمة إلى حق الطقل في اللعب وحثهم على المحافظة عليه.

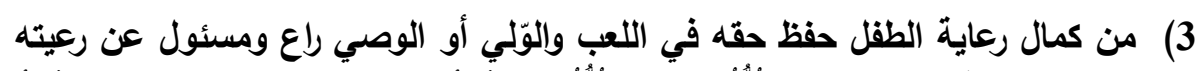

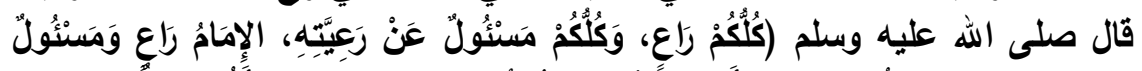

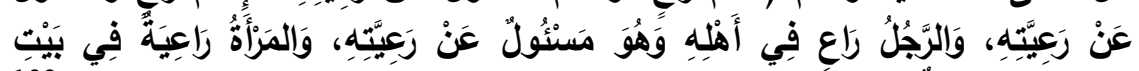

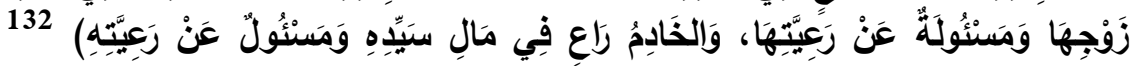

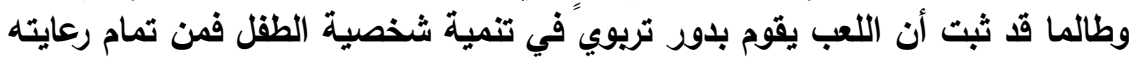
حفظ حقه في اللعب.

4) التربية الإسلامية تربية شاملة ترعى الإنسان في كل جوانب شخصيته ليكون فردا

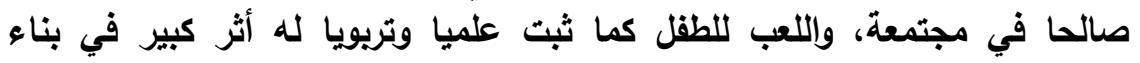
شخصية الفرد فعليه يصبح اللعب حقا للطقل ينبغي مراعاته والحفاظ عليه وليه. 
مجلة كلية التربية، جامعة الأزهر، العدد: (164 الجزء الثالث) يوليو لسنة 2015م

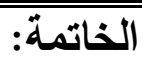

بعد بيان خصائص الطفولة، وخصائص اللعب وأهميته للطقل، و بعد توضيح أن للطقل حقوق فردية وشخصية.

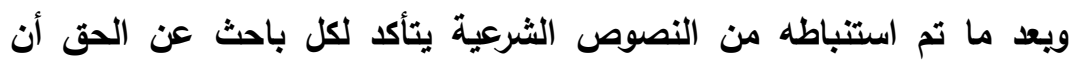

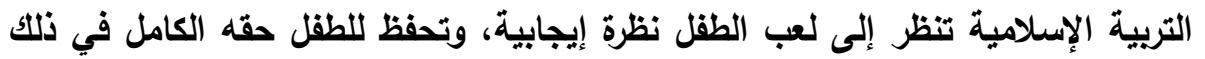

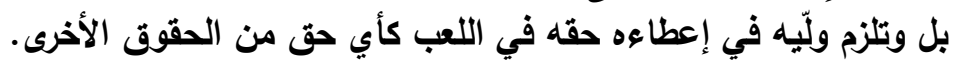




$$
\text { المراجع }
$$

$$
\text { 1. - م القرآن الكريم }
$$

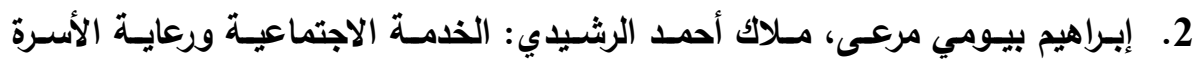

$$
\text { والطفولة، الكتب الجامعي الحديث، الإسكندرية دئ د.ت. }
$$

3. إبراهيم مدكور: حقوق الإنسان في الإسلام أول تقنين لمبادئ الثريعة الإسلامية فيما

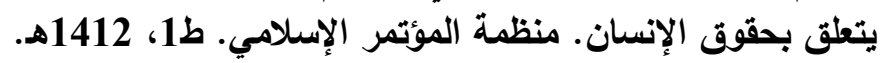

4. إبراهيم مدكور: حقوق الإنسان في الإسلام أول تقنين لمبادئ الثريعة الإسلامية فيما يتعلق بحقوق الإنسان.

$$
\text { 5. إبراهيم مصطفى وآخرون: المعجم الوسيط. دار الدعوة. القاهرة. }
$$

6. أبو حامد محمد بن محمد الغزالي: إحياء علوم الاين، دار المعرفة. بيروت،2004. 7. أحمد بلقيس، وتوفيق مرعى: الميسر في سيكولوجية اللعب. ط3، دار الفرقان.

$$
\text { عمان، 1987م. }
$$

8. أحمد بن محمد ابن عبد ريه الأندلسي: العقد الفريد، تحقيق مفيد محمد قميحة، دار

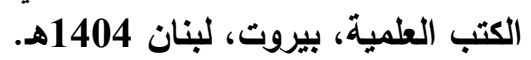

9. أحمد بن محمد بن علي الفيومي: المصباح المنير، مكتبة لبنان، بيروت.

10. أحمد زكى صالح (1979). علم النفس التريوي (ط.13). القاهرة: مكتبة النهضة المصرية.

11. أحمد عبد الحميد الثافعي، و خضر صلاح حسن (2000): دور اللعب في تنمية

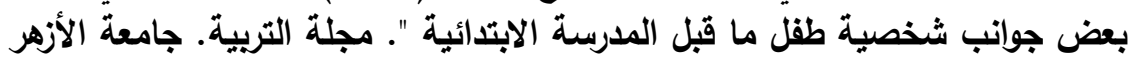

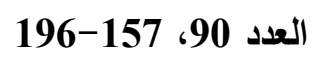

12. أحمد عبد الله: بناء الأسرة الفاضلة. دار البيان العربي. بيروت. 1410هـ. 13. أحمد مختار عبد الحميد عمر،معجم اللغة العربية المعاصرة. عالم الكتب. 2008م.

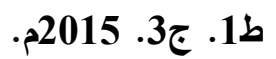

14. إسماعيل بن حماد الجوهري: الصحاح، دار العلم. بيروت، ط الثالثة، 1404هـ. 15. إعلان حقوق الطقل: الجمعية العامة للأمم المتحدة. 1386م. 
مجلة كلية التربية، جامعة الأزهر، العلد: (164 الجزء الثالث) يوليو لسنة 2015م

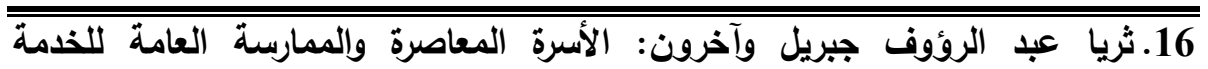

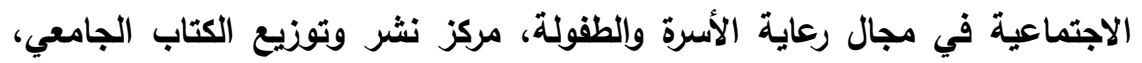

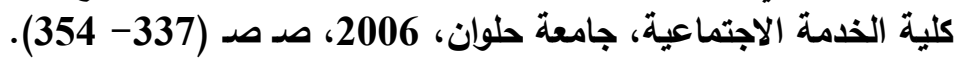

17. حامد زهران، علم نفس النمو، ط4، القاهرة: عالم الكتب 1988م.

18.حسن إبراهيم عبد العال: " اللعب مدخل وظيفي للتربية الإسلامية". دراسات تريوية.

المجلد السابع. الجزء (40) عائ العل : 1993م.

19.حسن شحاتة وآخرون: معجم المصطلحات التربوية والنفسية. الدار المصرية

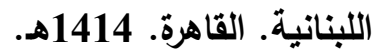

20. حسني نصار : تثريعات حماية الطقولة.، منشأة المعارف. الإسكندرية، (د.ت). 21. حسنين بوادي: حقوق الطقل بين الثريعة الإسلامية والقانون الدولي. الإسكندرية. دار الفكر الجامعي. 1426هـ دوادئ

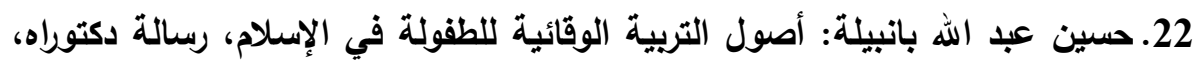
جامعة الإمام محمد بن سعود الإسلامية، كلية العلوم الاجتماعية، قسم التربية،

23. حقوق الطقل في الثرائع السماوية، دار الجمهورية للصحافة، القاهرة، 2006م.

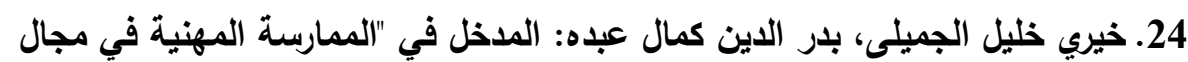

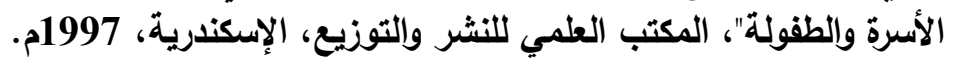

25.رأفت فريد سويلم: حقوق الطقل في الثريعة الإسلامية. دار ابن الجوزي. القاهرة، 1425 145

26.زكية عزيز (1956): حقوق الطقل خلال الأعوام الأولى. القاهرة: مكتبة النهضة

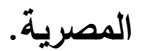

27. زهير الأعرجي: الأخلاق القرآنية: دار الزهراء. بيروت. 1987م. (255/1)

28. سهام مهذي جبار: الطفل في الثريعة الإسلامية ومنهج التربية النبوية.

29. الشريف علي بن محمد الجرجاني: كتاب التعريفات، دار الكتب العلمية - بيروت

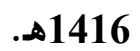

30. شفاء محمد القاضي: حقوق الطقل التعليمية والصحية وحق الحماية من سوء

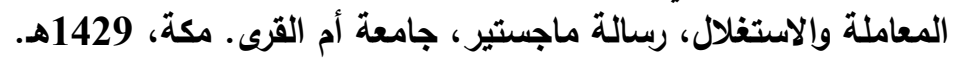


31.صالح ذياب الهندي: صورة الطفولة في التربية الإسلامية ، دار الفكر للنشر الأرور والتوزيع، عمان، الأردن، دان، 1990م.

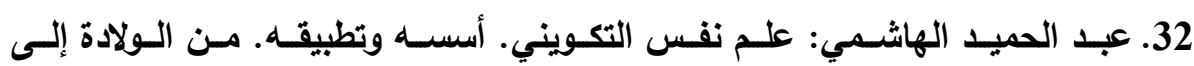

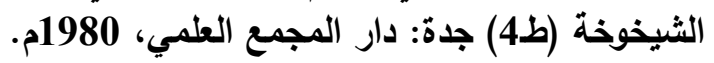

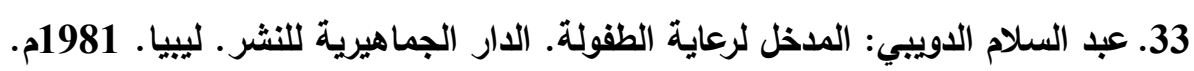
34. عبد الكريم البكار: تأسيس عقلية الطقل. مركز الراية للتنمية الفكرية. جدة. 1428هـ.

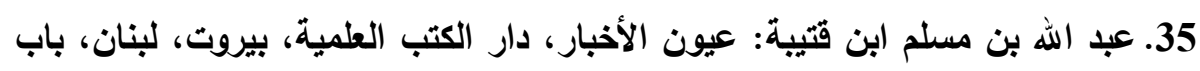

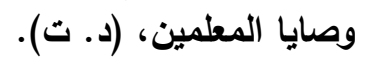

36. عبيدات وآخرون: البحث العلمي مفهومه -أدواته-أساليبه-، الأردن، دار الفكر. 1989

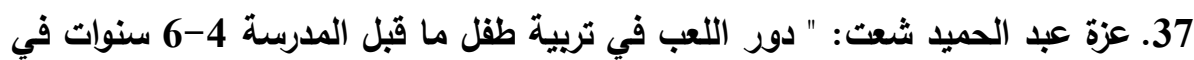

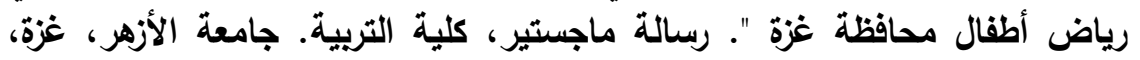

$$
\text { فلسطين، 2002م. }
$$

38. عفاف البابيدي: سيكولوجية اللعب. دار الفكر،عمان 1990م. 39. علاء حمروش: اللعب ووظائفه. مجلة ثقافة الطقل. المجلس القومي لثقافة الطفل، 1996م. عل عمون

40. علي أسعد وطفة: التربية والطفولة تصورات علمية وعقائد نقية، مجد المؤسسة

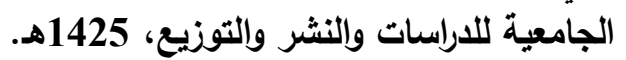

41. عمر الثيباني: فلسفة التربية الإسلامية. الدار العربية للكتاب. طرابلس. 1988م.

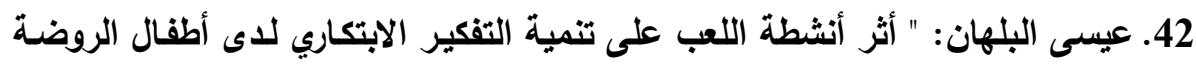

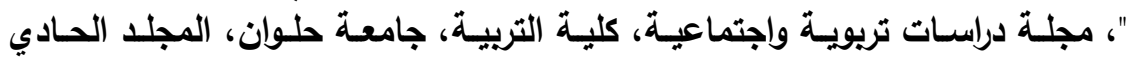

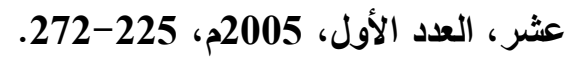
43. فؤاد البهي السيد: الجداول الإحصائية لعلم النفس والعلوم الإنسانية الأخرى. القاهرة: دار الفكر العربي، 1958م.

44. فاخر عامل: معالم التربية العامة والتربية العربية. دار العلم. بيروت. 1983م. ط5. 45. فاضل حنا: اللعب عند الطفل. دار مشرق. دمشق. 1999م. 
مجلة كلية التربية، جامعة الأزهر، العلد: (164 الجزء الثاثث) يوليو لسنة 2015م

46. فاطمة فرج العتيبي: حقوق الطفل ورعايته في الإسلام وفي السويد. رسالة ماجستير.

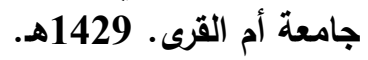

47. فتحية حسن سليمان: تريية الطقل بين الماضي والحاضر، القاهرة، دار الثروق، 1979

48. فوزية دياب (د.ت) نمو الطقل وتنشئته بين الأسرة ودور الحضانة (ط.3). القاهرة: مكتبة النهضة المصرية.

49. كريمان عبد المنعم سرور: التربية الرياضية والفتاة المسلمة، بحث مقدم إلى المؤتمر

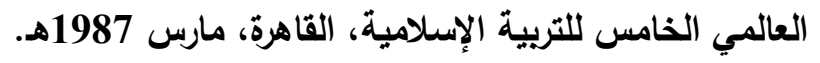

50.لجنة متخصصة: هموم الطقل العربي في المدينة العربية، ضمن سلسلة الطقل

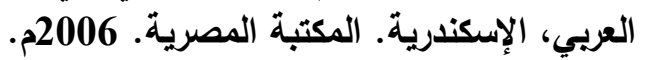

51. ليلي يوسف: سيكولوجية اللعب والتربية الرياضية. عالم الكتب، القاهرة، 1965م. 52. محمد الصالح: الطقل في الثريعة الإسلامية. مطبعة نهضة مصر . القاهرة. 1982م. 53. محمد القطب: المدخل الفقهي، 10/ 10. "الإسلام وحقوق الإنسان.

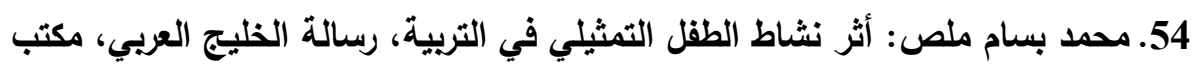

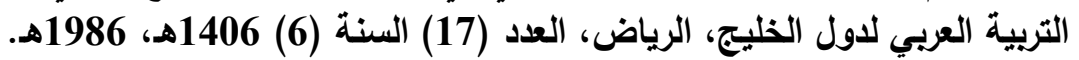

55. محمد بن إسماعيل البخاري: صحيح البخاري. بيروت. دار ابن كثير. 1407هـ. 56.محمد بن عيسى الترمذي: سنن الترمذي، تحقيق إبراهيم عوض، استانبول، دار

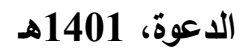

57. محمد بن يزيد ابن ماجة: سنن ابن ماجة، تحقيق محمد فؤاد عبد الباقي، بيروت.

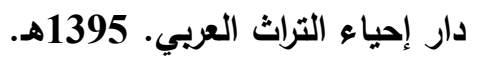

58. محمد بن يعقوب الفيروز آبادي: القاموس المحيط. المؤسسة العربية للطباعة والنشر، بيروت.

59. محمد حمزة الأهل: سيكولوجية ميول الأطفال القرائية. بغداد دائرة الشئون الثقافية

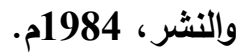

60.محد سعيد مرسي: فن تربية الأولاد في الإسلام. دار النشر والتوزيع الإسلامية،

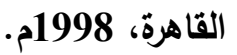

61. محمد شعلان (1977. الاضطرابات النفية في الأطفال. الجزء الأول. القاهرة: الجهاز المركزي للكتب الجامعية والمدرسية والوسائل التعليمية. 
62. محمد صالح العلوي: خطاب النبي صلى الله عليه وسلم للطقل المسلم وتطبيقاته

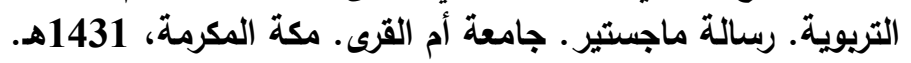

63. محمد صالح العلوي: خطاب النبي صلى الله عليه وسلم للطقل المسلم وتطبيقاته

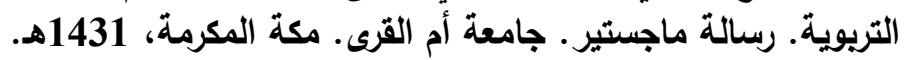

64. محمد عبد الحليم منسي: الروضة وإبداع الأطفال، دار المعرفة الجامعية، الإسكندرية، .1996

65. محمد على سكيكر : حقوق الطفل في الشرائع والتثريع، دار الجمهورية للصحافة، 2006.

66. محمد مكرم ابن منظور : لسان العرب. دار صادر بيروت،، 1410هـ (49/10). 67. محي الدين يحي بن شرف النووي: المنهاج في شرح صحيح مسلم، بيت الأفكار

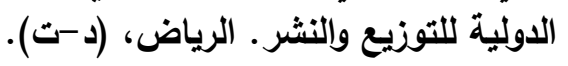

68. مخلا الطراونة: حقوق الطقل دراسة مقارنة في ضوء أحكام القانون الدولي والثريعة الأبة

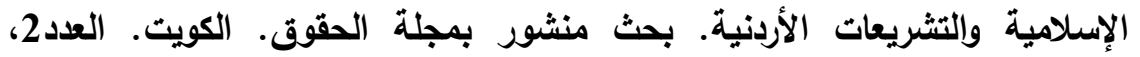
.2003

69. مسلم بن الحجاج أبو الحسن القشيري النيسابوري: صحيح مسلم، دار إحياء التراث. بيروت.

70. مصطقى أحمد الزرقا: المدخل الفقهي العام، دار الفكر، ط التاسعة. 71. نجيب إلياس برسوم. محمد مصطفى زيدان: المرشد النفسي إلى الحياة. القاهرة: دار نهضة مصر، 1965م.

72. نخبة من أساتذة جامعة عين شمس: حقوق الإنسان. 2006م.

73. نظمي أبو مصطفى، وعطاف أبو غالي: اتجاهات الوالدين نحو لعب الأطفال" دراسة

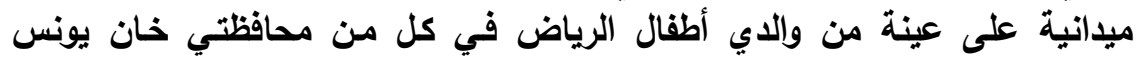

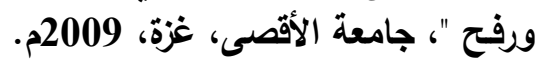

74.نعيمة محمد يونس، و عبد الفتاح صابر عبد الحميد: سيكولوجية اللعب والترويح

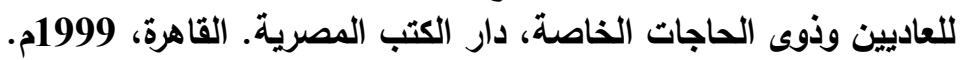
75. نوف محيي الدين: اللعب في حياة الأطفال: الطفل العربي والمستقبل. الكتاب العربي.

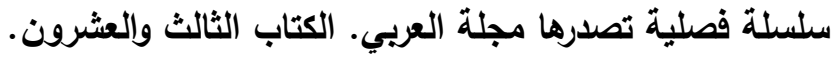




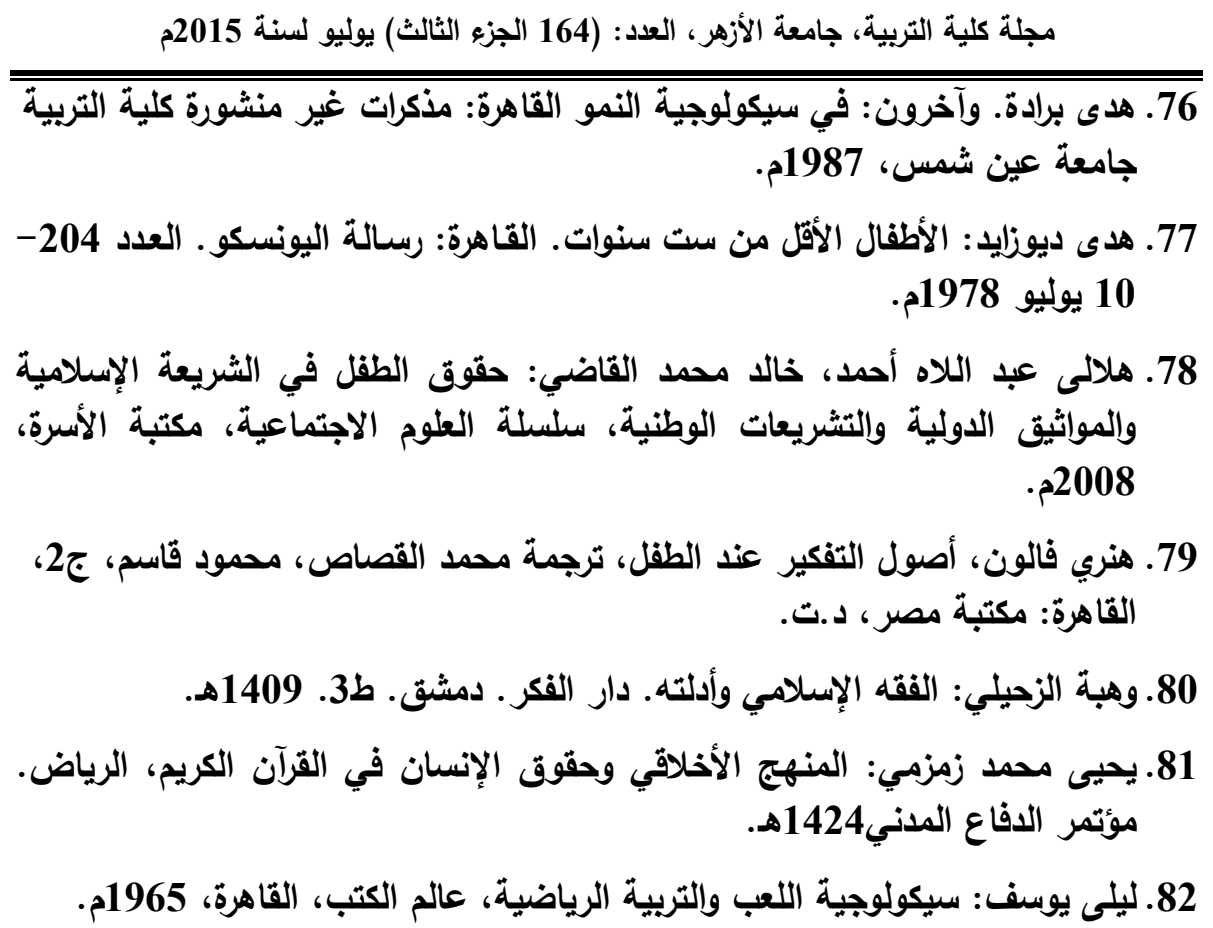

83. Aliwood J.(2002):Homogenizing Play: Governing Preschool Childhoods, Charles Sturt University, AARE - Australian Association for Research in Education

84. Downes T. (2000): Blending Play, Practice and Performance. Learning with Computers at home. University of Western Sydney, Macarthur. AARE - Australian Association for Research in Education

85. Encyclopedia of social work, Washington Dc, 19th ،1995., p (430).

86. Freeman,N. K. (2007): Preschoolers Perceptions of Gender Appropriate Toys and Their Parents Beliefs about Genderized Behaviors: Miscommunication, Mixed, Early Childhood Education Journal, vol. 34, No.(5) pp.357-366

87. Gleason, T (2005): Mothers and Fathers Attitudes Regarding Pretend Play in the Context of Imaginary Companions and of Child Gender" Journal of Developmental Psychology, vol. 51, No. (4) pp. 412 -436

88. Hamm, E. M. et al. (2006): Play Outcomes and Satisfaction with Toys and Technology of Young Children with Special 
مجلة كلية التريبة، جامعة الأزهر ، العدد: (164 الجزء الثالث) يوليو لسنة 2015م

Needs, Journal of Special Education Technology ،vol. 21, No. (1) pp. 29-35

89. Vickerius, M. \& Sandberg,A.(2006): The Significance of Play and environment around play, Early Child Development and care, vol. 76, No.(2) pp.207-217. 